Nevada

Environmental

Restoration

Project
DOE/NV--1328-REV. 1

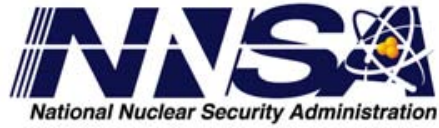

Streamlined Approach for Environmental Restoration (SAFER) Plan for Corrective Action Unit 114: Area 25 EMAD Facility

Nevada Test Site, Nevada

Controlled Copy No.:

Revision No.: 1

June 2010

Approved for public release; further dissemination unlimited.

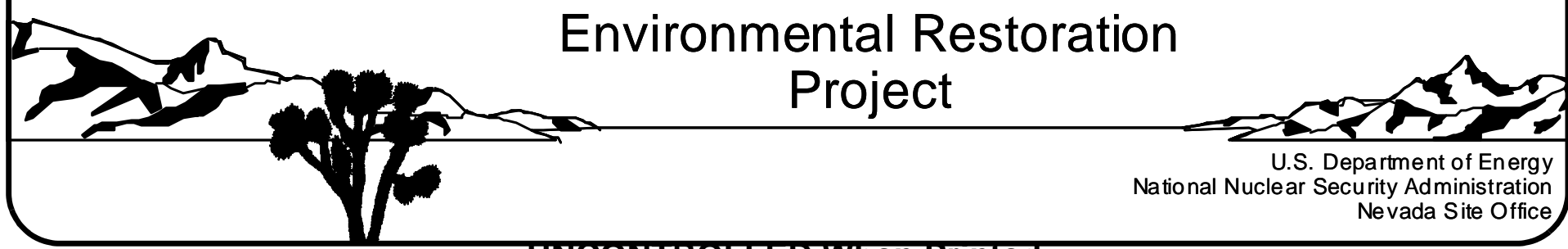


Available for sale to the public from:

U.S. Department of Commerce
National Technical Information Service
5301 Shawnee Road
Alexandria, VA 22312
Telephone: 800.553 .6847
Fax: 703.605.6900
E-mail: orders@ntis.gov
Online Ordering: $\underline{\text { htp://www.ntis.gov/help/ordermethods.aspx }}$

Available electronically at http://www.osti.gov/bridge

Available for a processing fee to U.S. Department of Energy and its contractors, in paper, from:

\author{
U.S. Department of Energy \\ Office of Scientific and Technical Information \\ P.O. Box 62 \\ Oak Ridge, TN 37831-0062 \\ Phone: 865.576 .8401 \\ Fax: 865.576.5728 \\ Email: reports@adonis.osti.gov
}

Reference herein to any specific commercial product, process, or service by trade name, trademark, manufacturer, or otherwise, does not necessarily constitute or imply its endorsement, recommendation, or favoring by the United States Government or any agency thereof or its contractors or subcontractors. 


\title{
STREAMLINED APPROACH FOR ENVIRONMENTAL RESTORATION (SAFER) PLAN FOR CORRECTIVE ACTION UNIT 114: AREA 25 EMAD FACILITY NEVADA TEST SITE, NEVADA
}

\author{
U.S. Department of Energy \\ National Nuclear Security Administration \\ Nevada Site Office \\ Las Vegas, Nevada
}

Controlled Copy No.:

Revision No.: 1

June 2010

Approved for public release; further dissemination unlimited.

Reviewed and determined to be UNCLASSIFIED.
Derivative Classifier: $\frac{\text { Joseph } \mathrm{P} . \text { Johnston/NNES CO }}{\text { (Name/personal identifier and position title) }}$
Signature: $\underline{\text { /S/ Joseph P. Johnston }}$
Date: $\underline{06 / 09 / 2010}$


STREAMLINED APPROACH FOR ENVIRONMENTAL RESTORATION (SAFER) PLAN FOR CORRECTIVE ACTION UNIT 114:

AREA 25 EMAD FACILITY

NEVADA TEST SITE, NEVADA

Approved by: _ /s/ Kevin J. Cabble

Date: 06/09/2010

Kevin J. Cabble

Federal Sub-Project Director

Industrial Sites Sub-Project

Approved by: _/s/ Robert F. Boehlecke

Date: 06/09/2010

Robert F. Boehlecke

Federal Project Director

Environmental Restoration Project 


\section{Table of Contents}

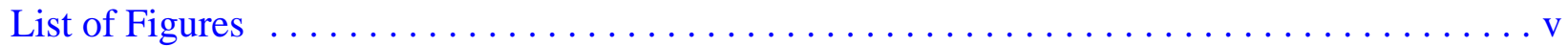

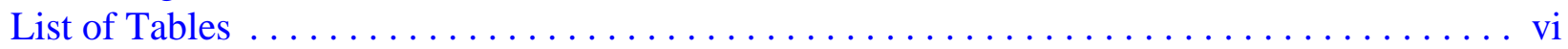

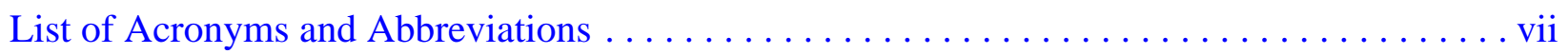

Executive Summary . . . . . . . . . . . . . . . . . . . . . . . . ES-1

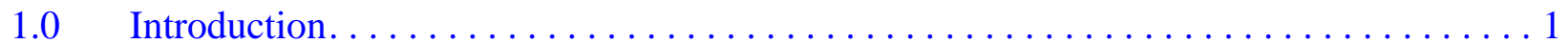

1.1 SAFER Process Description . . . . . . . . . . . . . . . . . 5

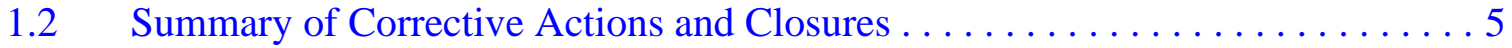

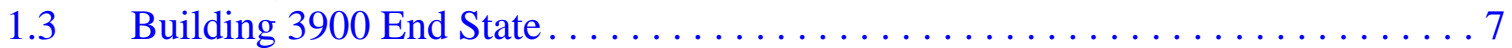

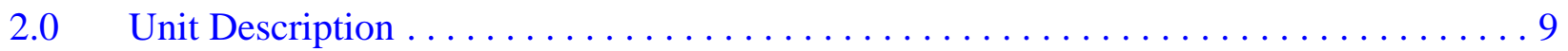

2.1 CAS $25-41-03$, EMAD Facility $\ldots \ldots \ldots \ldots \ldots \ldots \ldots \ldots \ldots \ldots \ldots \ldots \ldots \ldots \ldots \ldots \ldots$

2.1 .1 Hot Bay Complex.............................. 10

2.1.2 Operating Galleries and Master Control Room . . . . . . . . . . . 17

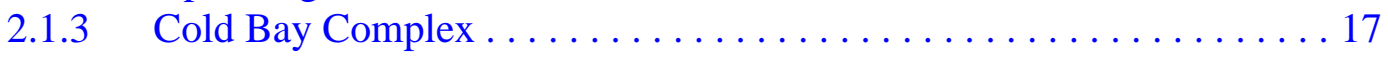

2.1.4 Machine and Repair Shops........................... 18

$2.1 .5 \quad$ Facility Support Areas . . . . . . . . . . . . . . . . . . . . . 18

2.2 History and Process Knowledge . . . . . . . . . . . . . . . . 19

2.3 Previous Investigations . . . . . . . . . . . . . . . . . . . 20

2.3.1 Potential Impacts of Existing Use Restrictions

to the CAU 114 CAI . . . . . . . . . . . . . . . . . . . 28

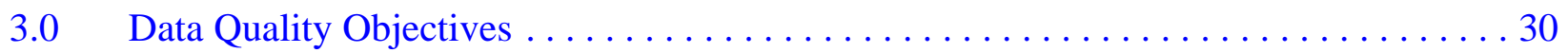

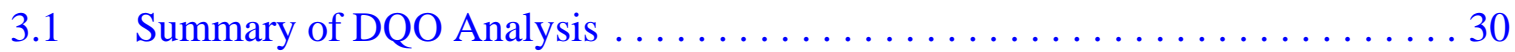

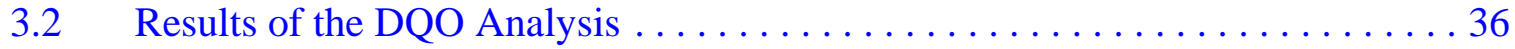

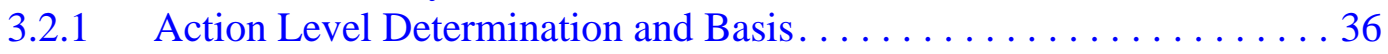

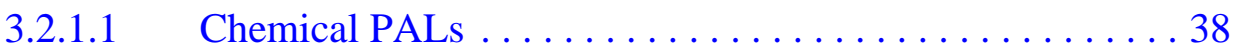

3.2.1.2 Total Petroleum Hydrocarbon PALs . . . . . . . . . . 38

3.2.1.3 Radionuclide PALs ..................... 39

3.2.2 Hypothesis Test . . . . . . . . . . . . . . . . . . . . 39

3.2 .3 Statistical Model . . . . . . . . . . . . . . . . . . . . . . 39

3.2.4 Design Description/Option. . . . . . . . . . . . . . . . . 39

3.2.5 Conceptual Site Model and Drawing ................... 40

$4.0 \quad$ Field Activities and Closure Objectives $\ldots \ldots \ldots \ldots \ldots \ldots \ldots \ldots \ldots \ldots \ldots \ldots \ldots$

4.1 Contaminants of Potential Concern $\ldots \ldots \ldots \ldots \ldots \ldots \ldots \ldots \ldots \ldots \ldots$

4.1 .1 Total Petroleum Hydrocarbons. . . . . . . . . . . . . . . . . . . . . 43

4.1.2 Volatile and Semivolatile Organic Compounds . . . . . . . . . . . . . . 44

4.1.3 Polychlorinated Biphenyls . . . . . . . . . . . . . . . . 44

4.1.4 Resource Conservation and Recovery Act Metals and Beryllium . . . . . 44

$4.1 .5 \quad$ Pesticides ........................... 44 


\section{Table of Contents (Continued)}

4.1.6 Radionuclides ................................... 45

$4.2 \quad$ Remediation ....................................... 45

4.2.1 Sampling for COCs and PSMs $\ldots \ldots \ldots \ldots \ldots \ldots \ldots \ldots \ldots \ldots$

$4.3 \quad$ Verification...................................... 48

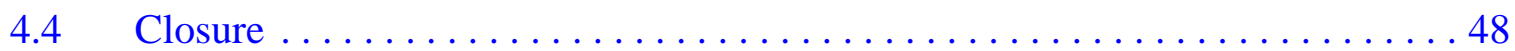

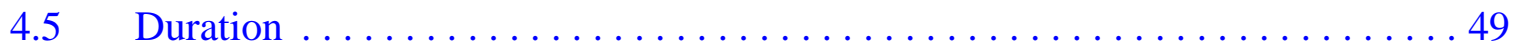

$5.0 \quad$ Reports and Records Availability .......................... 50

$6.0 \quad$ Investigation/Remediation Waste Management ..................... 51

$6.1 \quad$ Waste Minimization . . . . . . . . . . . . . . . . . . . . . . . . . . 51

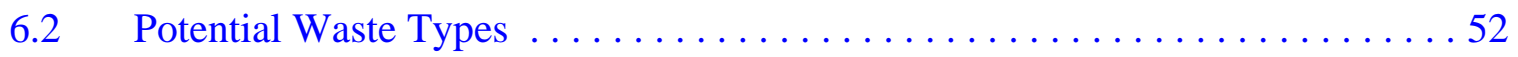

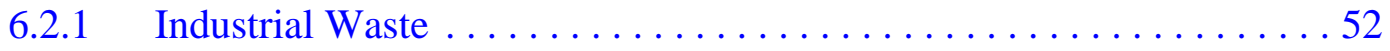

6.2.2 Low-Level Radioactive Waste . . . . . . . . . . . . . . . . 52

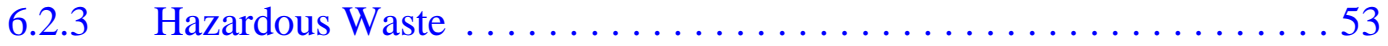

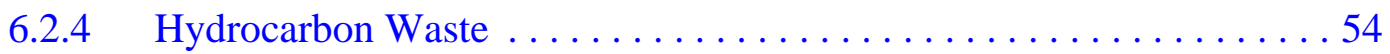

6.2 .5 Mixed Low-Level Waste .......................... 54

6.2.6 Toxic Substances Control Act Waste .................... 54

6.2.6.1 Polychlorinated Biphenyls .................... 55

6.2.6.2 Asbestos-Containing Material .................. 55

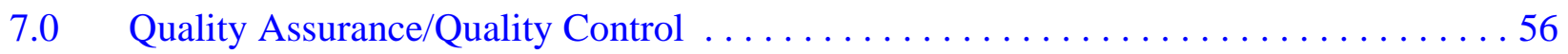

$7.1 \quad$ Sample Collection Activities ............................ 56

7.2 Applicable Laboratory/Analytical Data Quality Indicators . . . . . . . . . . 56

7.2.1 Precision ................................... 57

$7.2 .2 \quad$ Accuracy/Bias................................... 59

7.2 .3 Representativeness ...........................60 60

7.2 .4 Completeness ................................6 60

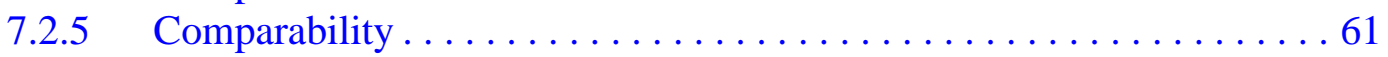

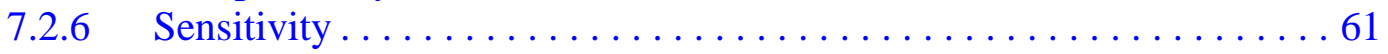

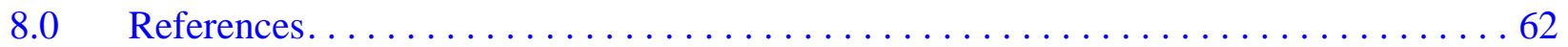

\section{Appendix A - Project Organization}

A.1.0 Project Organization $\ldots \ldots \ldots \ldots \ldots \ldots \ldots \ldots \ldots \ldots \ldots \ldots \ldots \ldots \ldots \ldots \ldots \ldots \ldots \ldots \ldots$

\section{Appendix B - Data Quality Objective Process}

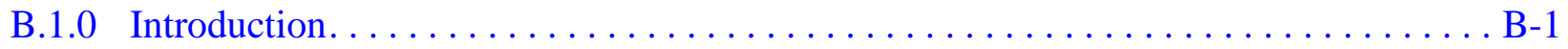

B.2.0 Step 1 - State the Problem.......................... B-2 


\section{Table of Contents (Continued)}

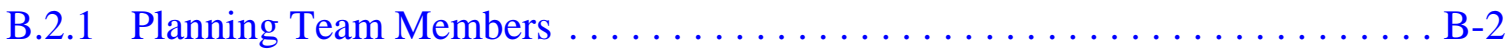

B.2.2 Conceptual Site Model .............................. B-2

B.2.2.1 Contaminant Release ........................ B-3

B.2.2.2 Potential Contaminants........................ B-4

B.2.2.3 Contaminant Characteristics..................... B-5

B.2.2.4 Site Characteristics . ......................... B-6

B.2.2.5 Migration Pathways and Transport Mechanisms ............ B-6

B.2.2.6 Land-Use and Exposure Scenarios . . . . . . . . . . . . . B-7

B.3.0 Step 2 - Identify the Goal of the Study ................... B

B.3.1 Decision Statements . . . . . . . . . . . . . . . . . . . . . . . B-9

B.3.2 Alternative Actions to the Decisions $\ldots \ldots \ldots \ldots \ldots \ldots \ldots \ldots \ldots . .6 \ldots \ldots$

B.3.2.1 Alternative Actions to Decision I . . . . . . . . . . . . . B-11

B.3.2.2 Alternative Actions to Decision II . . . . . . . . . . . . . B-12

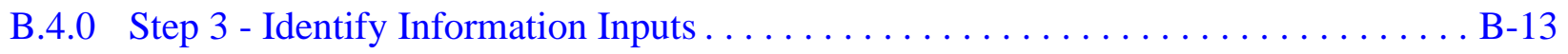

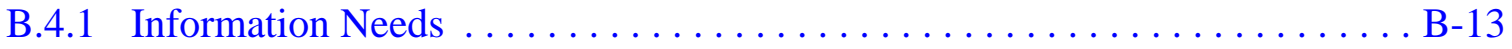

B.4.2 Sources of Information . . . . . . . . . . . . . . . . . . . .

B.4.2.1 Sample Locations ........................... B-14

B.4.2.2 Analytical Methods........................ B-15

B.5.0 Step 4 - Define the Boundaries of the Study $\ldots \ldots \ldots \ldots \ldots \ldots \ldots \ldots \ldots$ B-16

B.5.1 Target Populations of Interest. . . . . . . . . . . . . . . . . . . .

B.5.2 Spatial Boundaries ............................... B-16

B.5.3 Practical Constraints ................................

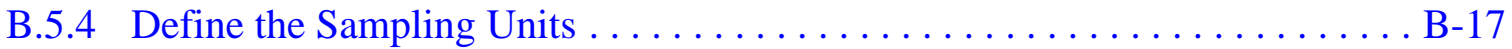

B.6.0 Step 5 - Develop the Analytic Approach ........................ B-18

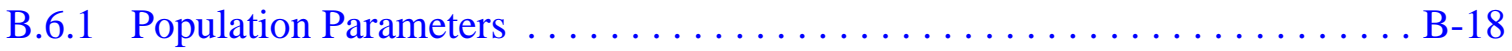

B.6.2 Action Levels .................................. B-18

B.6.2.1 Chemical PALs............................ B-19

B.6.2.2 Total Petroleum Hydrocarbon PALs $\ldots \ldots \ldots \ldots \ldots \ldots \ldots \ldots . . . \ldots$

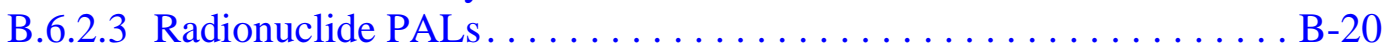

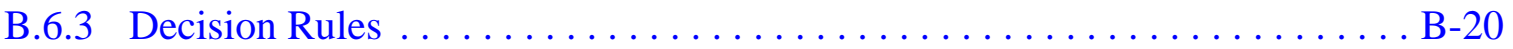

B.7.0 Step 6 - Specify Performance or Acceptance Criteria $\ldots \ldots \ldots \ldots \ldots \ldots \ldots$ B-21

B.7.1 Decision Hypotheses. . . . . . . . . . . . . . . . . . . . . . . . .

B.7.2 False Negative Decision Error $\ldots \ldots \ldots \ldots \ldots \ldots \ldots \ldots \ldots \ldots \ldots \ldots \ldots \ldots \ldots \ldots \ldots$

B.7.2.1 False Negative Decision Error for Judgmental Sampling . . . . . . . B B-21

B.7.3 False Positive Decision Error . . . . . . . . . . . . . . . . . . . B-23 


\section{Table of Contents (Continued)}

B.8.0 Step 7 - Develop the Plan for Obtaining Data $\ldots \ldots \ldots \ldots \ldots \ldots \ldots \ldots \ldots$ B-24

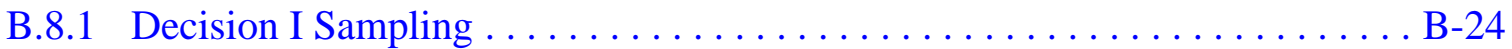

B.8.2 Sampling Design $\ldots \ldots \ldots \ldots \ldots \ldots \ldots \ldots \ldots \ldots \ldots \ldots \ldots \ldots \ldots \ldots \ldots \ldots \ldots \ldots, 24$

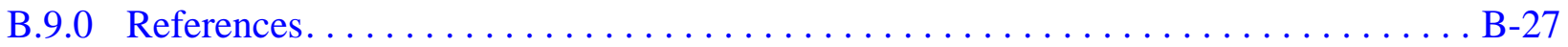

Appendix C - Nevada Division of Environmental Protection Comments 


\section{List of Figures}

Number

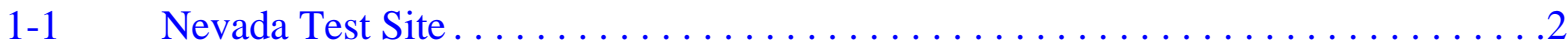

1-2 CAU 114, CAS Location Map $\ldots \ldots \ldots \ldots \ldots \ldots \ldots \ldots \ldots \ldots \ldots \ldots \ldots \ldots \ldots \ldots \ldots$

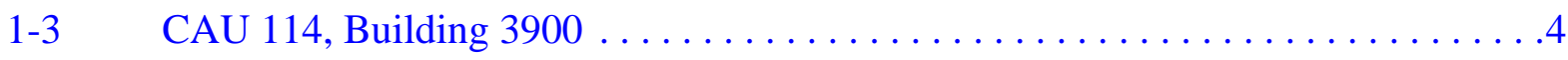

1-4 CAU 114 Closure Decision Process ............................

2-1 E-MAD Facility First-Floor Layout $\ldots \ldots \ldots \ldots \ldots \ldots \ldots \ldots \ldots \ldots \ldots \ldots$

2-2 E-MAD Facility Second-Floor Layout........................

2-3 E-MAD Facility Third-Floor Layout $\ldots \ldots \ldots \ldots \ldots \ldots \ldots \ldots \ldots \ldots \ldots$

2-4 E-MAD Facility Fourth-Floor Layout $\ldots \ldots \ldots \ldots \ldots \ldots \ldots \ldots \ldots \ldots \ldots \ldots$

2-5 E-MAD Facility Basement Layout $\ldots \ldots \ldots \ldots \ldots \ldots \ldots \ldots \ldots \ldots \ldots \ldots \ldots \ldots \ldots$

2-6 Previous Investigations Associated with E-MAD Facility Operations . . . . . . . 24

3-1 Risk-Based Corrective Action Decision Process ...................... 37

3-2 Conceptual Site Model Diagram for CAU $114 \ldots \ldots \ldots \ldots \ldots \ldots \ldots . \ldots . \ldots \ldots$

3-3 Conceptual Site Model for CAU $114 \ldots \ldots \ldots \ldots \ldots \ldots \ldots \ldots \ldots \ldots \ldots \ldots \ldots$

B.3-1 SAFER Closure Decision Process for CAU $114 \ldots \ldots \ldots \ldots \ldots \ldots \ldots$ B-10 


\section{List of Tables}

Number

Title

Page

2-1 Available Maximum Radiological Measurements for the E-MAD Facility. . . . . 21

2-2 Previous CAU Investigations Associated with the E-MAD Facility . . . . . . . 25

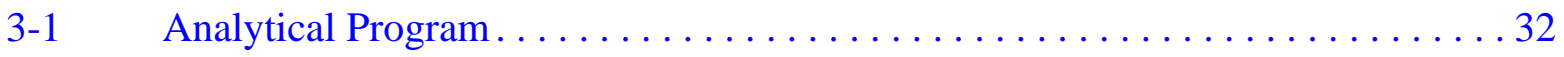

3-2 Constituents Reported by Analytical Methods . . . . . . . . . . . . . . 33

3-3 Analytical Requirements for Radiological COPCs for CAU $114 \ldots . . \ldots . . .34$

3-4 Analytical Requirements for Chemical COPCs for CAU $114 \ldots \ldots$. . . . . . . 35

4-1 Sampling Approach for CAU $114 \ldots \ldots \ldots \ldots \ldots \ldots \ldots \ldots \ldots \ldots \ldots \ldots \ldots \ldots \ldots \ldots$

4-2 Known or Anticipated Potential Source Materials . . . . . . . . . . . . . . 4 47

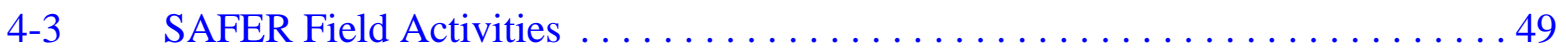

7-1 Laboratory and Analytical Performance Criteria for CAU 114 DQIs . . . . . . . 58

B.2-1 Conceptual Site Model Description for CAS 25-41-03 in CAU $114 \ldots . . . .$. B-4

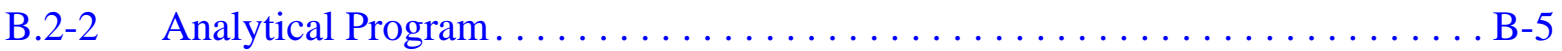

B.2-3 Land-Use and Exposure Scenarios $\ldots \ldots \ldots \ldots \ldots \ldots \ldots \ldots \ldots \ldots$

B.5-1 Spatial Boundaries of CAS $25-41-03 \ldots \ldots \ldots \ldots \ldots \ldots \ldots \ldots \ldots \ldots$

B.5-2 Practical Constraints for the CAU 114 Field Investigation . . . . . . . . . . . B-17

B.8-1 Known or Anticipated Potential Source Materials . . . . . . . . . . . . . B-25 


\section{List of Acronyms and Abbreviations}

Ac

ACM

Am

AST

ASTM

bgs

CAA

CAI

CAS

CAU

CFR

$\mathrm{cm}$

Co

COC

COPC

CR

Cs

CSA

CSM

DOE

DOT

$\mathrm{dpm} / 100 \mathrm{~cm}^{2}$

DQI

DQO

DRO

DU
Actinium

Asbestos-containing material

Americium

Aboveground storage tank

American Society for Testing and Materials

Below ground surface

Corrective action alternative

Corrective action investigation

Corrective action site

Corrective action unit

Code of Federal Regulations

Centimeter

Cobalt

Contaminant of concern

Contaminant of potential concern

Closure report

Cesium

Cell Service Area

Conceptual site model

U.S. Department of Energy

U.S. Department of Transportation

Disintegrations per minute per 100 square centimeters

Data quality indicator

Data quality objective

Diesel-range organics

Depleted uranium 


\section{List of Acronyms and Abbreviations (Continued)}

\begin{tabular}{|c|c|}
\hline E-MAD & Engine Maintenance, Assembly, and Disassembly \\
\hline EPA & U.S. Environmental Protection Agency \\
\hline ETSM & Engine Transport System Maintenance \\
\hline $\mathrm{Eu}$ & Europium \\
\hline FAL & Final action level \\
\hline FFACO & Federal Facility Agreement and Consent Order \\
\hline $\mathrm{ft}$ & Foot \\
\hline gal & Gallon \\
\hline HEPA & High-efficiency particulate air \\
\hline HHTT & Hot Hold Transfer Tunnel \\
\hline HVAC & Heating, ventilation, and air conditioning \\
\hline HWAA & Hazardous waste accumulation area \\
\hline IDW & Investigation-derived waste \\
\hline in. & Inch \\
\hline $\mathrm{K}$ & Potassium \\
\hline $\mathrm{lb}$ & Pound \\
\hline LCS & Laboratory control sample \\
\hline LLW & Low-level waste \\
\hline $\mathrm{m}$ & Meter \\
\hline $\mathrm{M} \& \mathrm{O}$ & Management and operating \\
\hline MDC & Minimum detectable concentration \\
\hline $\mathrm{mg} / \mathrm{kg}$ & Milligrams per kilogram \\
\hline $\mathrm{mrem} / \mathrm{yr}$ & Millirem per year \\
\hline MS & Matrix spike \\
\hline NAC & Nevada Administrative Code \\
\hline NAD & North American Datum \\
\hline
\end{tabular}




\section{List of Acronyms and Abbreviations (Continued)}

$\mathrm{Nb}$

NCRP

ND

NDEP

NERVA

NNES

NNSA/NSO

NRDS

NSTec

NTS

NTSWAC

OPS

PAL

$\mathrm{Pb}$

PCB

PPE

ppm

PSM

$\mathrm{Pu}$

QA

QAPP

QC

RBCA

RBSL

RCA

RCRA
Niobium

National Council on Radiation Protection and Measurements

Normalized difference

Nevada Division of Environmental Protection

Nuclear Engine for Rocket Vehicle Application

Navarro Nevada Environmental Services, LLC

U.S. Department of Energy, National Nuclear Security Administration Nevada Site Office

Nuclear Rocket Development Station

National Security Technologies, LLC

Nevada Test Site

Nevada Test Site Waste Acceptance Criteria

Overhead positioning system

Preliminary action level

Lead

Polychlorinated biphenyl

Personal protective equipment

Parts per million

Potential source material

Plutonium

Quality assurance

Quality Assurance Project Plan

Quality control

Risk-based corrective action

Risk-based screening level

Radiologically controlled area

Resource Conservation and Recovery Act 


\section{List of Acronyms and Abbreviations (Continued)}

\begin{tabular}{|c|c|}
\hline RESRAD & Residual Radioactive \\
\hline $\mathrm{RL}$ & Reporting limit \\
\hline RMA & Radioactive material area \\
\hline RPD & Relative percent difference \\
\hline RSL & Regional screening level \\
\hline SAFER & Streamlined Approach for Environmental Restoration \\
\hline SAIC & Science Applications International Corporation \\
\hline SFDP & Spent Fuel Demonstration Program \\
\hline SNJV & Stoller-Navarro Joint Venture \\
\hline $\mathrm{Sr}$ & Strontium \\
\hline SSTL & Site-specific target level \\
\hline SVOC & Semivolatile organic compound \\
\hline TBD & To be determined \\
\hline Th & Thorium \\
\hline $\mathrm{Tl}$ & Thallium \\
\hline $\mathrm{TPH}$ & Total petroleum hydrocarbons \\
\hline TSCA & Toxic Substances Control Act \\
\hline $\mathrm{U}$ & Uranium \\
\hline UR & Use restriction \\
\hline UTM & Universal Transverse Mercator \\
\hline VOC & Volatile organic compound \\
\hline $\mathrm{yd}^{3}$ & Cubic yard \\
\hline$\mu g / 100 \mathrm{~cm}^{2}$ & Micrograms per 100 square centimeters \\
\hline$\mu \mathrm{R} / \mathrm{hr}$ & Microroentgens per hour \\
\hline$\% \mathrm{R}$ & Percent recovery \\
\hline
\end{tabular}




\section{Executive Summary}

This Streamlined Approach for Environmental Restoration (SAFER) Plan addresses the actions needed to achieve closure for Corrective Action Unit (CAU) 114, Area 25 EMAD Facility, identified in the Federal Facility Agreement and Consent Order (FFACO). Corrective Action Unit 114 comprises the following corrective action site (CAS) located in Area 25 of the Nevada Test Site:

\section{- 25-41-03, EMAD Facility}

This plan provides the methodology for field activities needed to gather the necessary information for closing CAS 25-41-03. There is sufficient information and process knowledge from historical documentation and investigations of similar sites regarding the expected nature and extent of potential contaminants to recommend closure of CAU 114 using the SAFER process. Additional information will be obtained by conducting a field investigation before selecting the appropriate corrective action for CAS 25-41-03. It is anticipated that the results of the field investigation and implementation of corrective actions will support a defensible recommendation that no further corrective action is necessary. If it is determined that complete clean closure cannot be accomplished during the SAFER, then a hold point will have been reached and the Nevada Division of Environmental Protection (NDEP) will be consulted to determine whether the remaining contamination will be closed under the alternative corrective action of closure in place. This will be presented in a closure report that will be prepared and submitted to NDEP for review and approval.

The CAS will be investigated based on the data quality objectives (DQOs) developed on April 30, 2009, by representatives of NDEP and the U.S. Department of Energy (DOE), National Nuclear Security Administration Nevada Site Office. The DQO process was used to identify and define the type, amount, and quality of data needed to determine and implement appropriate corrective actions for CAS 25-41-03.

The following text summarizes the SAFER activities that will support the closure of CAU 114:

- Perform site preparation activities (e.g., utilities clearances, radiological surveys).

- Collect samples of materials to determine whether potential source material (PSM) is present that may cause the future release of a contaminant of concern to environmental media. 
- If no PSMs are present at the CAS, establish no further action as the corrective action.

- If a PSM is present at the CAS, either:

- Establish clean closure as the corrective action. The material to be remediated will be removed and disposed of as waste, or

- Establish closure in place as the corrective action and implement the appropriate use restrictions.

- Confirm the selected closure option is sufficient to protect human health and the environment.

This SAFER Plan has been developed in accordance with the FFACO that was agreed to by the State of Nevada; DOE, Environmental Management; U.S. Department of Defense; and DOE, Legacy Management. Under the FFACO, this SAFER Plan will be submitted to NDEP for approval. Fieldwork will be conducted following approval of the plan. 


\subsection{Introduction}

This Streamlined Approach for Environmental Restoration (SAFER) Plan addresses the actions necessary for the closure of Corrective Action Unit (CAU) 114: Area 25 EMAD Facility, located at the Nevada Test Site (NTS), Nevada. It has been developed in accordance with the Federal Facility Agreement and Consent Order (FFACO) that was agreed to by the State of Nevada; U.S. Department of Energy (DOE), Environmental Management; U.S. Department of Defense; and DOE, Legacy Management (FFACO, 1996; as amended March 2010).

Note: The acronym used for the Engine Maintenance, Assembly, and Disassembly Facility sometimes appears in documents as "E-MAD" and sometimes as "EMAD." Throughout this document, "E-MAD” will be used except when "EMAD” appears in document titles and FFACO descriptions.

A SAFER may be performed when the following criteria are met:

- Conceptual corrective actions are clearly identified (although some degree of investigation may be necessary to select a specific corrective action before completion of the corrective action investigation $[\mathrm{CAI}])$.

- Uncertainty of the nature, extent, and corrective action must be limited to an acceptable level of risk.

- The SAFER Plan includes decision points and criteria for making data quality objective (DQO) decisions.

The purpose of the CAI will be to document and verify the adequacy of existing information; to affirm the decision for either clean closure, closure in place, or no further action; and to provide sufficient data to implement the corrective action. The actual corrective action selected will be based on characterization activities implemented under this SAFER Plan. This SAFER Plan identifies decision points developed in cooperation with the Nevada Division of Environmental Protection (NDEP), where the DOE, National Nuclear Security Administration Nevada Site Office (NNSA/NSO) will reach consensus with NDEP before beginning the next phase of work.

Corrective Action Unit 114 is located in Area 25 of the NTS, which is approximately 65 miles northwest of Las Vegas, NV (Figure 1-1). Corrective Action Unit 114 is composed of Corrective Action Site (CAS) 25-41-03, EMAD Facility, which consists of potential future releases from wastes suspected to contain a material that may cause the release of a potential source material (PSM) to environmental media (Figure 1-2). 


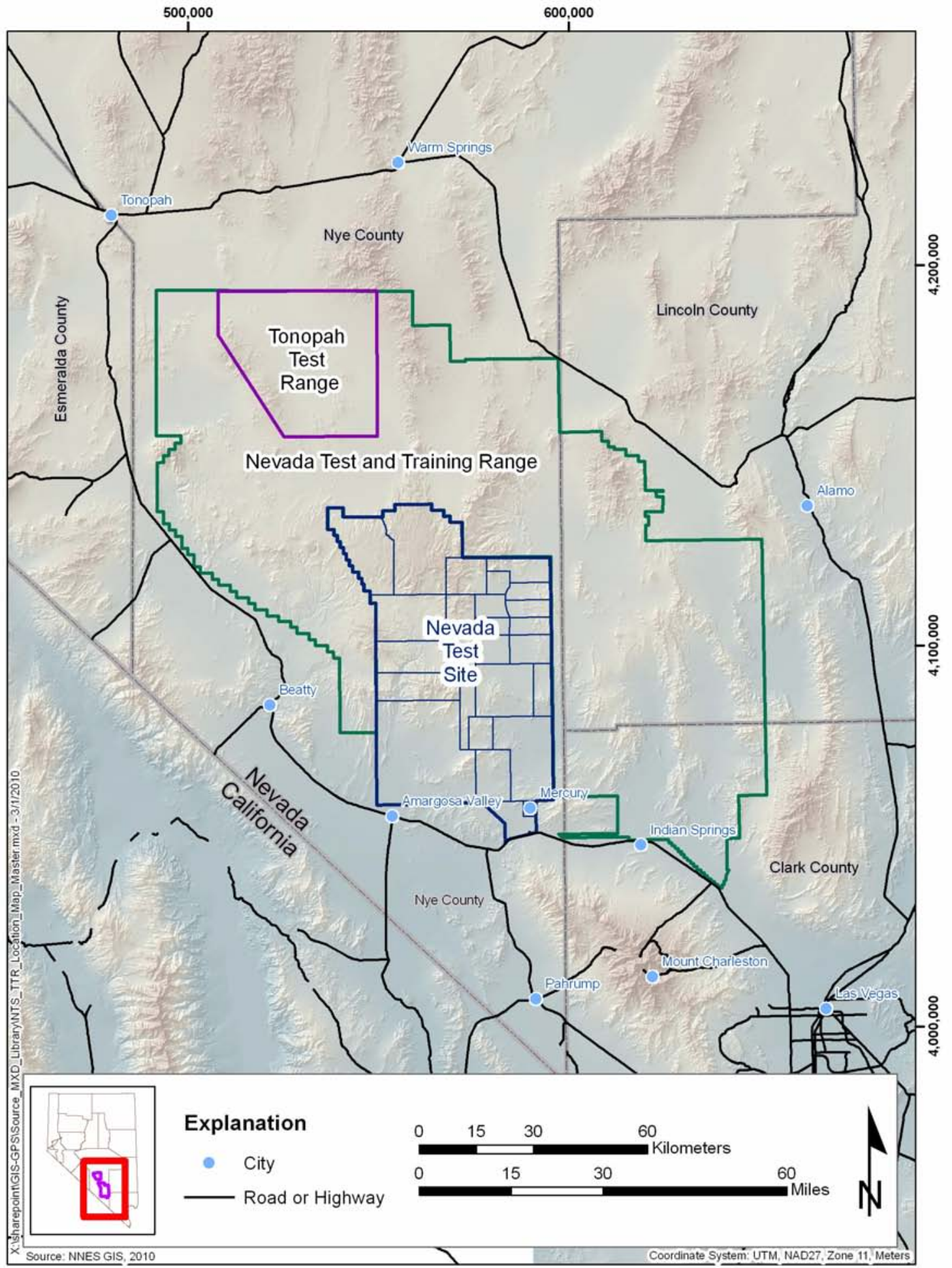

Figure 1-1

Nevada Test Site 


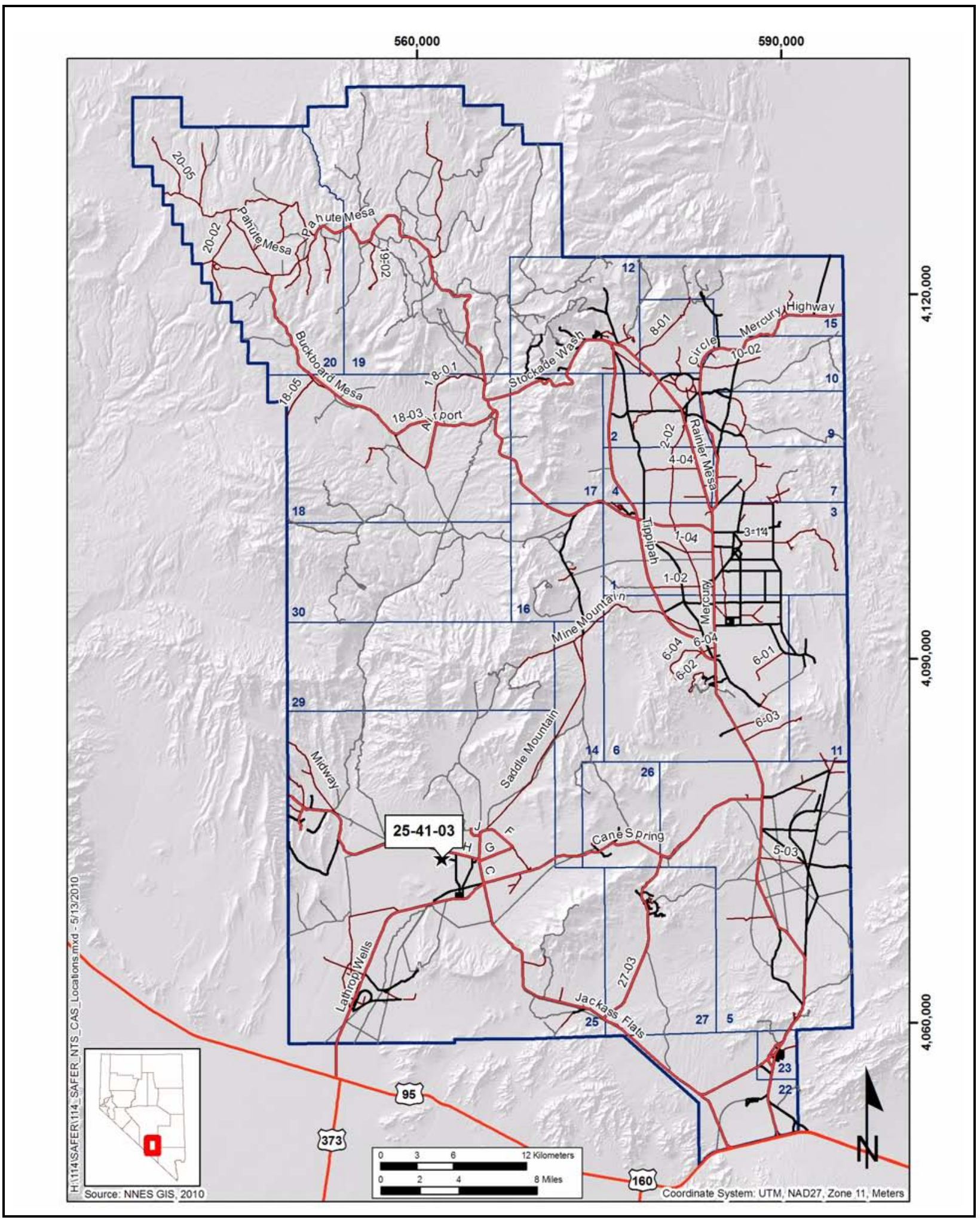

Figure 1-2

CAU 114, CAS Location Map 
Figure 1-3 shows an aerial photograph of the E-MAD Building (Building 3900). Any releases identified during the field investigation that are associated with Building 3900 operations and support activities will be included in the scope of the CAI.

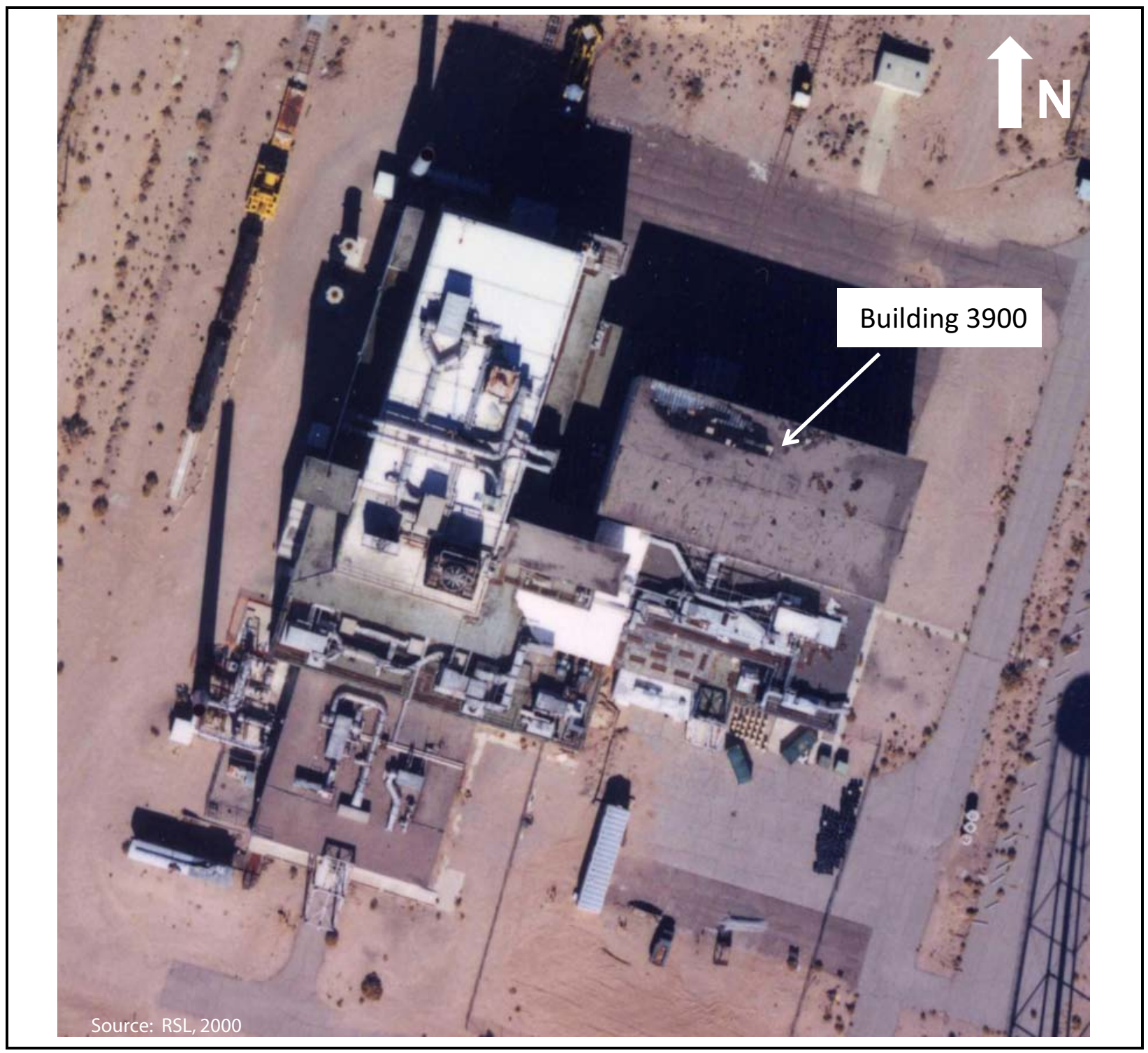

Figure 1-3

CAU 114, Building 3900

There is sufficient information and process knowledge from historical documentation and investigations of similar sites (i.e., the expected nature and extent of contaminants of potential concern [COPCs]) to recommend closure of CAU 114 using the SAFER process (FFACO, 1996; as amended March 2010). 


\subsection{SAFER Process Description}

Corrective action units that may be closed using the SAFER process have conceptual corrective actions that are clearly identified. Consequently, corrective action alternatives (CAAs) can be chosen before completing a CAI, given anticipated investigation results.

The SAFER process combines elements of the DQO process and the observational approach to plan and conduct closure activities. The DQOs are used to identify the problem and define the type and quality of data needed to complete closure of each CAS or CAS component. The purpose of the CAI phase is to verify the adequacy of existing information used to determine the chosen corrective action and to confirm that closure objectives were met.

Use of the SAFER process allows for technical decisions to be made based on incomplete but sufficient information, and the experience of the decision maker. Based on a detailed review of historical documentation, there is sufficient process knowledge to close CAU 114 using the SAFER process. Any uncertainties are addressed by documented assumptions that are verified by sampling and analysis, data evaluation, and onsite observations, as necessary. Closure activities may proceed simultaneously with site characterization as sufficient data are gathered to confirm or disprove the assumptions made during selection of the corrective action. If, at any time during the closure process, new information is discovered that indicates that closure activities should be revised, closure activities will be re-evaluated as appropriate.

\subsection{Summary of Corrective Actions and Closures}

The decision process for closure of CAU 114 is summarized in Figure 1-4. This process starts with the initial CAI in which the appropriate target population(s) within each CAS component (defined in the DQO process, Appendix B) is sampled. The objectives of the field activities are to determine whether PSM is present. The process ends with closure of the site based on laboratory analytical results of the samples and the preparation of a closure report (CR). Decision points that require a consensus be reached between NNSA/NSO and NDEP before continuing are indicated in Figure 1-4. 


\section{SAFER Decision Flow Logic Diagram}

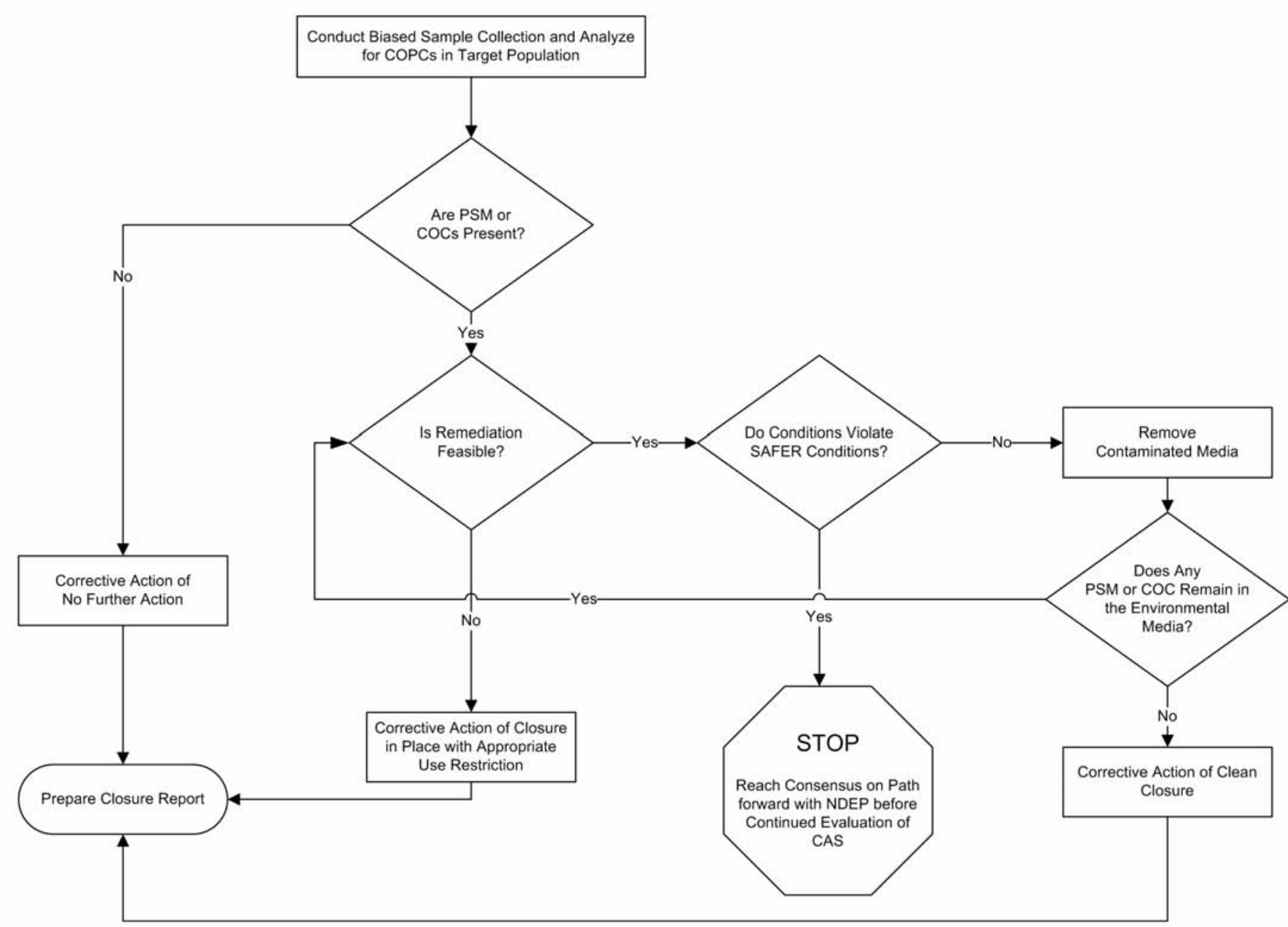

Figure 1-4

CAU 114 Closure Decision Process 
In addition to the previously discussed hold/decision points, work may be temporarily suspended until the issue can be satisfactorily resolved if any of the following unexpected conditions occur:

- Conditions outside the scope of work are encountered.

- Radiological screening yields results that require an upgrade in procedures to continue survey work in specific areas.

- Elevated levels of additional contaminants of concern (COCs) are found that were not originally identified as being present at the CAS.

- Unexpected conditions, including unexpected waste and/or contamination, are encountered.

- Other COCs are detected that would require re-evaluating a disposal pathway, such as with hazardous or low-level waste (LLW).

- Unsafe conditions or work practices are encountered.

The targeted corrective action is clean closure and will include removal of contaminated media and identified PSMs (see Section 3.1 for a description of PSM criteria). The alternative corrective action of closure in place with implementation of appropriate use restrictions (URs) will be performed only if complete removal of PSMs cannot be accomplished during the SAFER. There is the potential for implemented URs to be removed following demolition of Building 3900 if it becomes feasible to remove the PSM during demolition activities. For example, it may not be technically feasible to remove certain lead-shielding items (that meet PSM criteria) from inside concrete walls until demolition activities take place, allowing more efficient access to these items.

\subsection{Building 3900 End State}

The FFACO closure for CAU 114 using the SAFER process will include determining whether contaminants exist in environmental media or PSM as described in Section 1.2. Although the planned physical end state for Building 3900 is demolition and restoration of the area around the E-MAD Facility, these activities will occur independent of FFACO closure. Certain best management practices completed during the CAI to mitigate health and safety hazards, provide 
access to sampling locations, or facilitate future demolition will also occur outside the FFACO scope of the CAU 114 SAFER Plan. These activities may include the following:

- Asbestos identification and abatement

- Removal of readily removable nonhazardous wastes (e.g., process wastewater, used oils, debris) 


\subsection{Unit Description}

This section summarizes the operational history, process knowledge, and available characterization information for CAU 114. Process knowledge has been obtained through review of historical documents, engineering drawings, maps, and interviews with past and present NTS employees. Based on the available information regarding the E-MAD Facility, assumptions were made to develop a conceptual site model (CSM) that describes the most probable scenario for the current conditions at the site (see Section 3.2.5).

The scope of CAU 114 will include any environmental releases associated with CAS 25-41-03 (defined in Sections 2.1 and 2.2). Not included in the scope of CAU 114 are Building 3901 (Engine Transport System Maintenance [ETSM] Building), the railroad tracks on the exterior of Building 3900 (CAU 539), and the E-MAD Compound (CAU 566). Building 3901 is currently on the active roles for Defense Programs and may be included in the FFACO at a later date. The exterior tracks, Building 3901, and the E-MAD Compound will not be addressed further in this document.

\subsection{CAS 25-41-03, EMAD Facility}

This CAS consists of the potential releases to soil associated with historic operations at Building 3900. Building 3900 is located in an area of approximately 25 acres surrounded by a chain-link perimeter fence. Entry to the site is through a security gate at the northeast corner of the chain-link fence. A large asphalt-paved area is at the north side of the building, and railroad tracks are embedded in the blacktop running from the north end of the building beyond the perimeter fence into Area 26.

Building 3900 is an approximately 100,000-square-foot, four-story building that is 80 feet (ft) high. The exterior of Building 3900 is irregular in both height and configuration, with the walls constructed of either concrete (with rebar), asbestos-coated corrugated steel, or concrete block. In general, walls requiring shielding are constructed of concrete, while all other walls are constructed of corrugated steel or concrete block. While there are multiple shielded and unshielded loading doors and personnel access doors, there are no exterior windows in the building (DRI, 1996). The roofs of the building are at various floor levels, and most areas are surrounded by guardrails housing a variety of 
heating, ventilation, and air-conditioning (HVAC) equipment. The interior of Building 3900 consists of three main floors, a partial basement, and a one-room fourth floor. There are approximately 44 rooms that are divided among the following functional areas described in Sections 2.1.1 through 2.1.5. The functional areas are (1) the Hot Bay Complex, (2) the Operating Galleries and Master Control Room, (3) the Cold Bay Complex, (4) the Machine and Repair Shops, and (5) the Facility Support areas. Figures 2-1 through 2-5 show the floor plans for Building 3900.

\subsubsection{Hot Bay Complex}

The Hot Bay Complex is arranged as a north-south linear progression of shielded areas making up the western half of the facility. The northern-most room is the Hot Bay, which extends south to the Hot Hold Transfer Tunnel (HHTT), which is flanked by the East and West Process Cells. The HHTT leads to the Cell Service Area (CSA) and 12 smaller post-mortem hot cells. The entire Hot Bay is a posted as a Contamination Area. See Figure 2-1 for locations of these rooms.

\section{Hot Bay}

The Hot Bay is a three-story hot cell (140 ft long, $66 \mathrm{ft}$ wide, $76 \mathrm{ft}$ high) consisting of 5- to 6-ft-thick concrete walls containing 17 lead-glass shielding windows and a 32-inch (in.) thick concrete ceiling that provides shielding for remote assembly and disassembly of irradiated materials. Railroad tracks that extend north-south from door to door are set in the concrete floor which features a 1-ft-wide gutter with drains around the perimeter. The main access for hot material to the Hot Bay was by railcar or truck through a 5-ft-thick, 400-ton rolling concrete door (37 ft high, $22 \mathrm{ft}$ wide). Transfer of material to the post-mortem cells via the HHTT was by a smaller railcar through a rolling steel door (18 ft wide, $29 \mathrm{ft}$ high). Special Hot Bay equipment and features included the following:

- A 40-ton overhead bridge crane with a 10-ton hook

- An overhead position system that had capabilities of a retractable rigid-mast crane and bridge-mounted manipulator that handled up to a 20-ton load

- A 35-ft diameter turntable with an 80-ton turning capacity, and a 2.5-by-2.5-ft manway that provided access to the turntable-drive access tunnel, which measured $4 \mathrm{ft}$ wide, $17 \mathrm{ft}$ long, and $12 \mathrm{ft}$ deep

- Two sidewall manipulators mounted on the east wall, each with a 35-ft arm capable of handling up to 600 pounds (lb) 
TAU 114 SAFER Plan

Section: 2.0

Revision: 1

Date: June 2010

Page 11 of 68

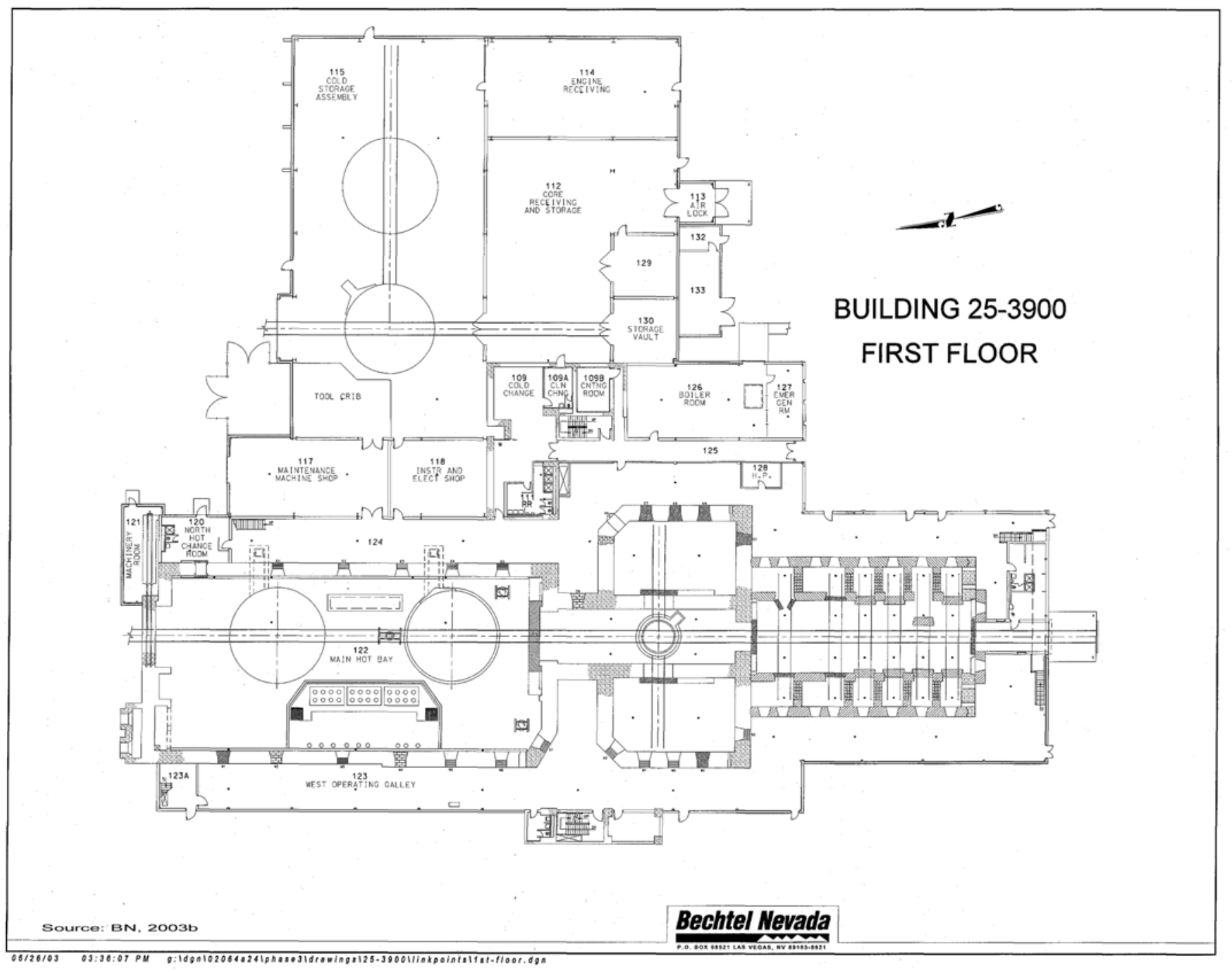

Figure 2-1

E-MAD Facility First-Floor Layout

UNCONTROLLED When Printed 


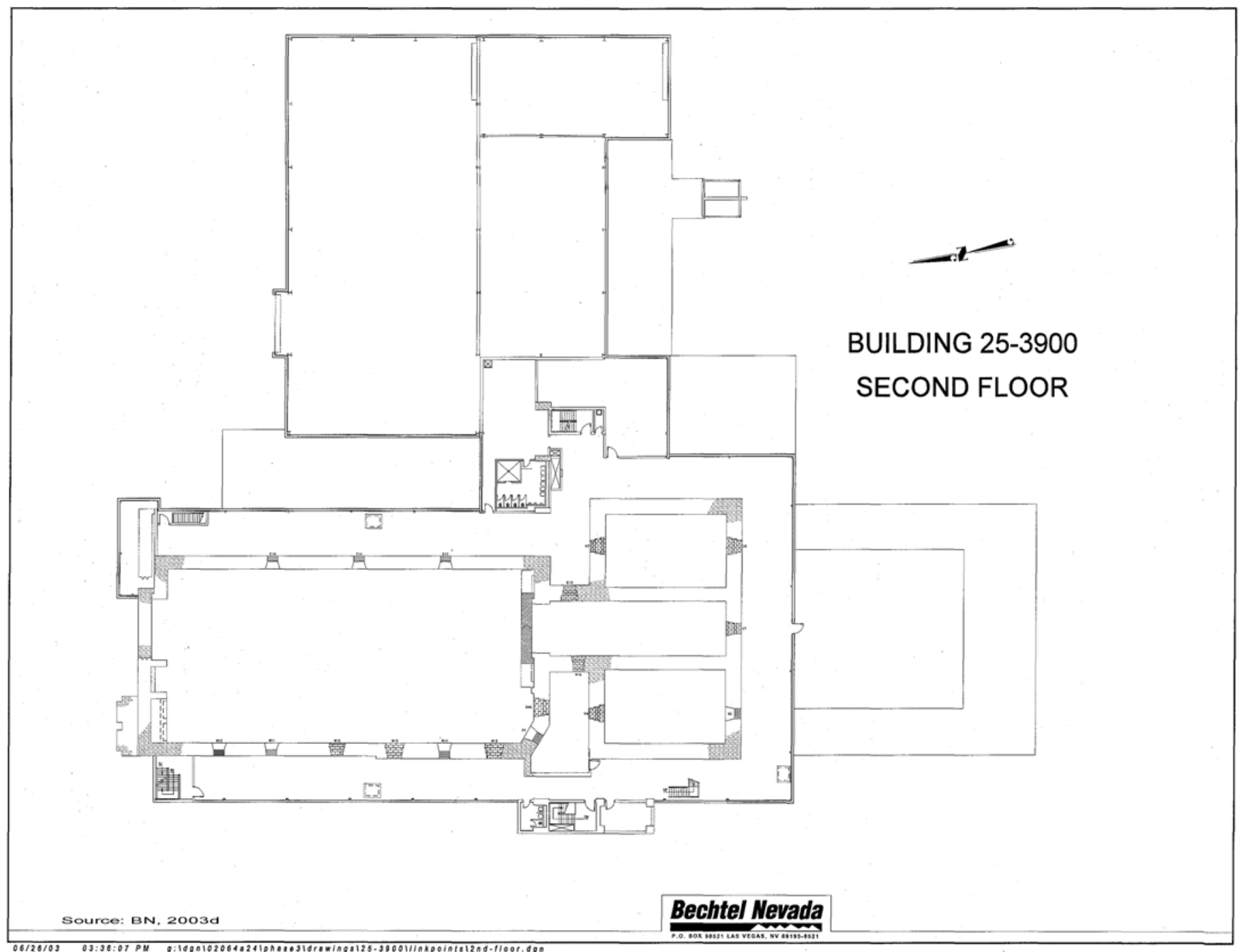

Figure 2-2

E-MAD Facility Second-Floor Layout 


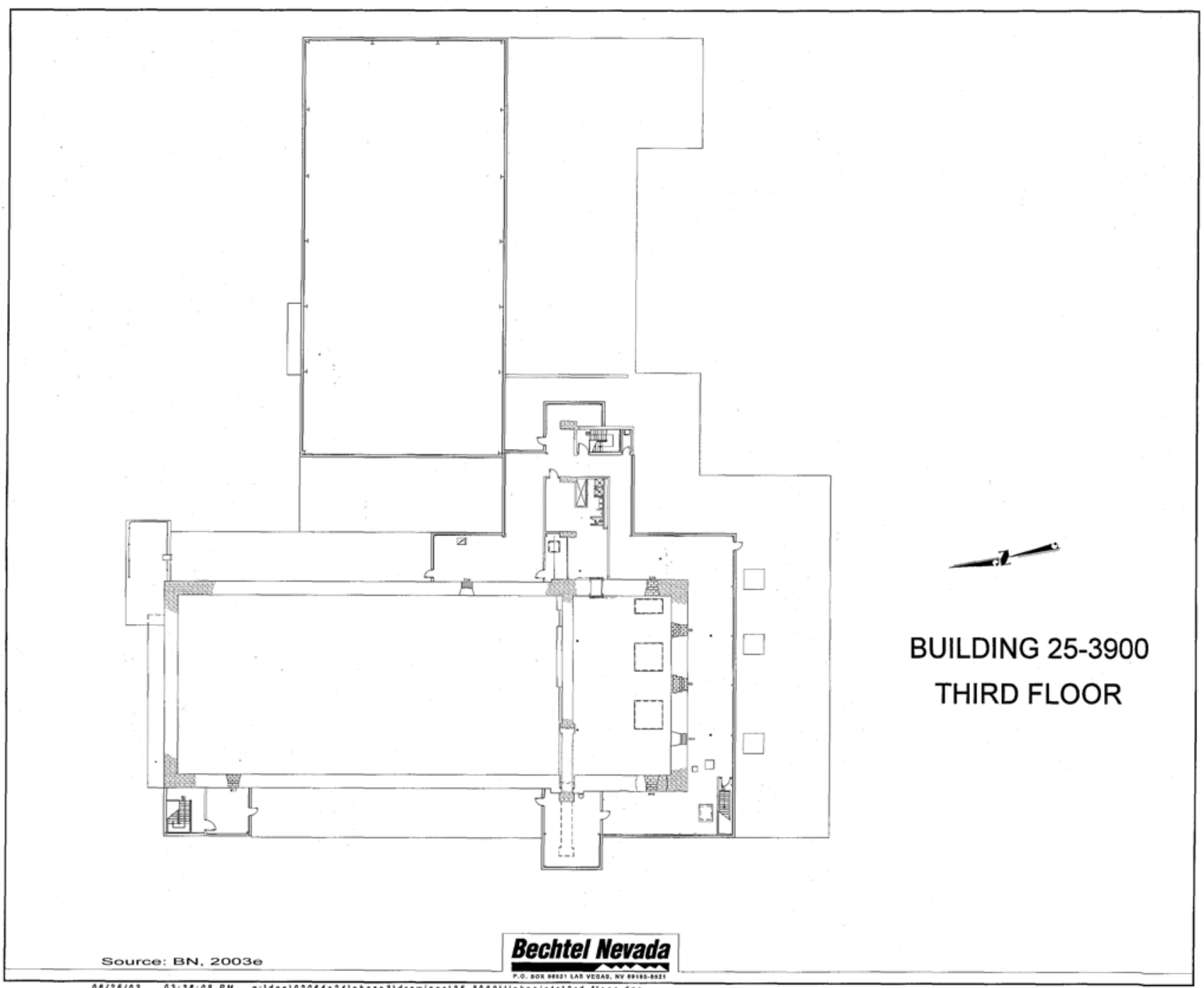

Figure 2-3

E-MAD Facility Third-Floor Layout 


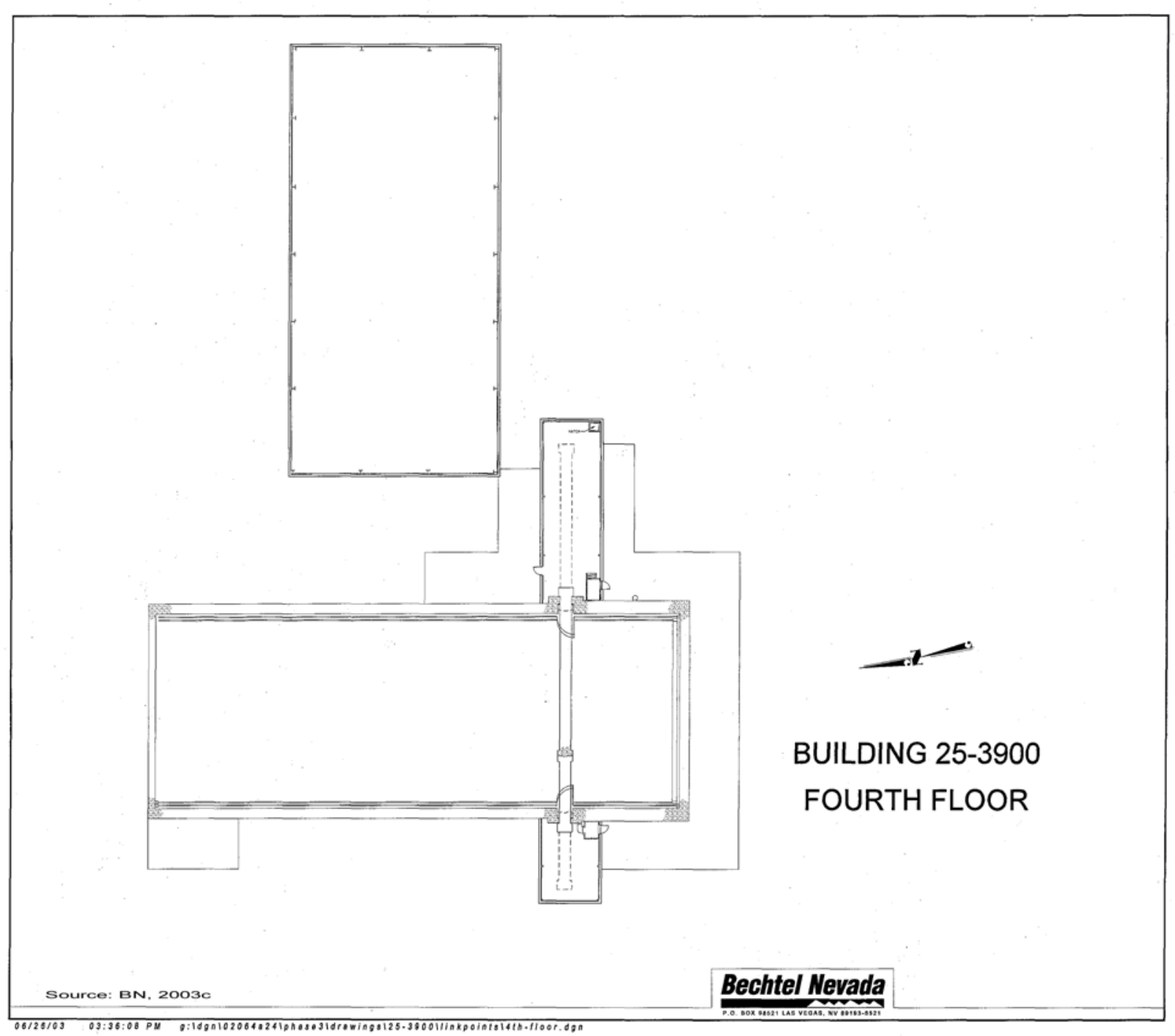

Figure 2-4

E-MAD Facility Fourth-Floor Layout 
CA 114 SAFER Plan

Section: 2.0

Revision: 1

Date: June 2010

Page 15 of 68

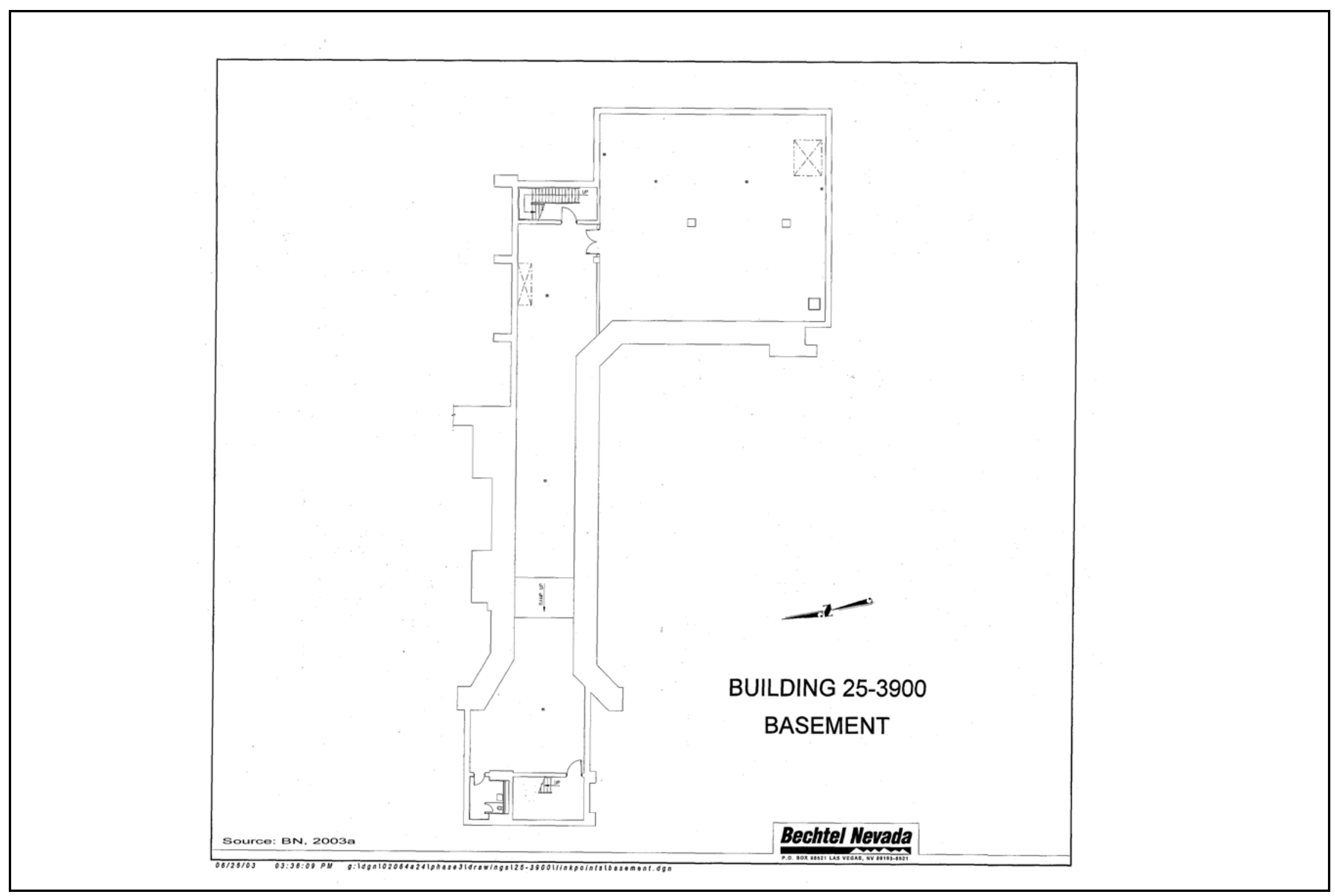

Figure 2-5

E-MAD Facility Basement Layout

UNCONTROLLED When Printed 
- Three scanning and photographic periscopes.

- Ten master-slave manipulators at each of the first-floor viewing windows on the east wall.

- A remote-operated system to transport materials from the north to south end of the facility via the railroad track.

- A shielded fuel storage pit in the floor (5 ft wide, $26 \mathrm{ft}$ long, and $13 \mathrm{ft}$ deep) with 6-ft-thick concrete roof plugs (removable by crane). A lag storage pit in the floor (27 ft wide, $58 \mathrm{ft}$ long, $23 \mathrm{ft}$ deep). Smaller service pits including a survey pit ( $2 \mathrm{ft}$ diameter, $14 \mathrm{ft}$ deep), a weld pit ( $2 \mathrm{ft}$ diameter, $20 \mathrm{ft}$ deep), and a transfer pit ( $2 \mathrm{ft}$ diameter, $27 \mathrm{ft}$ deep).

- A service balcony featuring a heavy concrete shield door used to close off the area so maintenance operations could be performed on the crane while irradiated materials were exposed in the main Hot Bay. The fourth floor consisted of a single small room used to service the shield door and provide access to the roof.

\section{Hot Hold Transfer Tunnel}

The HHTT is a concrete shielding area connecting the Hot Bay to the disassembly and examination cells and serves as a holding and transfer area for radioactive components. The area is equipped with a 15 -ft turntable with a 75,000-lb load capacity. Materials were remotely transferred to the Process Cells or post-mortem cells via a "dolly" mounted on the railroad tracks. At least one of the "dolly" cars is still located in the HHTT.

\section{East and West Process Cells}

The East and West Process Cells (each 46 by 28 by $29 \mathrm{ft}$ ), located at each side of the HHTT, were designed for the disassembly of the reactor core into its basic components. It was reported that the East Process Cell was never activated, and viewing windows, equipment, and lighting were not installed (DRI, 1996). The West Process Cell had four shielded windows (one is reported to be filled in with electrical equipment), each equipped with master-slave manipulator arms (currently only one window has a set). A steel shield door separates this space from the HHTT.

\section{Cell Service Area and Post-mortem Cells}

South of the HHTT is the CSA, a long, rectangular space that allows for the remote rail transfer of irradiated materials into any one of the 12 post-mortem (hot) cells. A 7 1/2-ton crane and a bridge-mounted manipulator serviced this area. According to the Atomic Energy Commission, 90 percent of the remote lab work was performed in these cells (DRI, 1996). On each side of the CSA 
are two large (16-by-10-by-15-ft) and four small (8-by-10-by-15-ft) post-mortem cells. Each cell has a shielded viewing window with master-slave manipulators and was serviced by a flat car for moving materials between the cell and the CSA (at least two cars remains in the HHTT). A steel shield door at the south end of this area leads to an airlock entry beyond which is a truck loading station serviced by a 25-ton monorail crane.

\subsubsection{Operating Galleries and Master Control Room}

The Operating Galleries were work areas on the "cold” side of the Hot Bay Complex on the first, second, and third floors and served as a protected area for personnel to work at the remote viewing control stations for all hot cells. These areas have asbestos-containing floor tiles, shared concrete walls with the hot cells, steel panel or concrete block walls along the perimeter, and concrete or steel ceilings. More than 40 small manipulator arms were originally located at the first and second-floor viewing windows and a periscope for detailed viewing was typically installed next to the arms. Various electric panels, gauges, and other equipment are found throughout the operating galleries.

The Master Control Room is located on the second floor and has a wide angle view into the Hot Bay through a shielding window. The Master Control Room functioned as the control center for operating the remote handling equipment (e.g., overhead crane, turntables, shield doors), remote railroad switches (controlled E-MAD and other Area 25 facilities), and telecommunication and video systems. Equipment was shut down, or selectively powered from this area.

\subsubsection{Cold Bay Complex}

The Cold Bay complex makes up the east side of the facility and comprises the Cold Bay, the Receiving and Storage area, and the Office area (originally the Engine Receiving Room).

\section{Cold Bay}

The Cold Bay, used for the receipt and assembly of nuclear rocket engines without the reactor core, is 140 by 72 by $60 \mathrm{ft}$ and features a 40-ton crane (with a 10-ton hook) and a 34-ft turntable capable of turning an 80-ton load. A 2.5-by-2.5-ft manway provides access to the turntable-drive. The facility railroad tracks enter the Cold Bay from the north wall through a 45-ft tall rolling metal door, extend across the turntable, and end inside the Receiving and Storage area. A second set of tracks run 
east-west in the concrete floor and end at the turntable. The north and east walls, and the upper portion of the west wall, are metal. The south wall and the lower portion of the west wall are concrete block. The ceiling is corrugated metal supported by steel trusses. On the south wall are a set of double steel casement doors leading to the Receiving and Storage area. A welding shop occupied the northwest corner of the Cold Bay and provides direct access to the electrical and machine shops.

\section{Receiving and Storage Area}

The main floor of this space is " $\mathrm{L}$ " shaped due to the location of two smaller rooms (Bonded Material Storage Room and Security Vault). The main area has access to an airlock entry at the south end that consists of two sets of double steel casement doors. The floor is concrete with railroad tracks running into the main area. The walls are concrete block, except for the steel south exterior wall. A 10-ton overhead bridge crane services this area.

\section{Office Area}

The Office area is located southeast of the Cold Bay and was originally designed to be the Engine Receiving Room. This area was instead divided into 10 office cubicles and an open reception area. The second floor contains several other areas designated for use as office work stations.

\subsubsection{Machine and Repair Shops}

The shops area, located adjacent to the Cold Bay, comprises a machine shop, electric shop, and welding shop that had the basic capabilities necessary for facility equipment fabrication, checkout, maintenance, and repair. A 5-ton bridge crane over the machine shop enabled the handling and movement of heavy items.

\subsubsection{Facility Support Areas}

The Facility Support areas include the boiler room containing two hot water boilers, a hot water pump, and an emergency generator; the compressor room containing air compressors, air-conditioning and refrigeration units, vacuum pumps, and the chilled water distribution system; the counting room; the HVAC control console; and the electrical equipment room containing electrical supply systems. The HVAC system includes two large exhaust stacks (one each at the northwest and southwest corners of the facility). Each stack is $114 \mathrm{ft}$ tall and equipped with a washdown system 
from which process water would flow to numerous spray nozzles within the stack. Wastewater drains to an adjacent drywell which consists of 3 cubic yards $\left(\mathrm{yd}^{3}\right)$ of "broken stone.” An engineering drawing shows a sump pit with a drain line to the drywell of the south stack (AEC/NASA, 1963). It is unknown whether a similar sump pit was installed for the north stack.

Aqueous systems that supported the facility include hot process water, cold process water, potable hot water, potable cold water, heating hot water, condenser water, and chilled water. A 75,000-gallon (gal)-capacity elevated water tank that is located near the southeast corner of the compound serviced Building 3900. Waste systems include the main sanitary sewer system and radioactive waste system (see Section 2.3 for previous CAU investigations related to these systems).

\subsection{History and Process Knowledge}

The E-MAD Facility is one of seven separate but interconnected complexes associated with the Nuclear Rocket Development Station (NRDS) in Area 25 in support of the Rover program, whose goal was the development of nuclear rocket reactors for use in the space program (DRI, 1996). The E-MAD Facility supported the second phase of that program consisting of the design and testing of nuclear powered rockets in the Nuclear Engine for Rocket Vehicle Application (NERVA) project (1965 to 1973). The NERVA engines were assembled in the Cold Bay, transported to the Engine Test Stand for testing, and then returned to E-MAD, where remote handling, inspections, and additional testing activities were conducted in the Hot Bay and post-mortem cells.

From 1977 to 1982, the Westinghouse Electric Corporation hosted the Spent Fuel Demonstration Program (SFDP), which involved testing and development activities related to the dry storage of spent nuclear fuel assemblies (DOE/NV, 1983). Primary program activities included receipt of spent fuel assemblies; design and development of sealed canisters for storage demonstrations; and performance of fuel calorimetry and canister gas sampling. The spent fuel program demonstrated three dry spent fuel storage concepts: (1) aboveground storage within two 252-in. high, 104-in. diameter reinforced concrete silos; (2) near surface dry well storage within four steel casing liners grouted into a shallow hole drilled between the rails on the west set of the railroad tracks; and (3) air-cooled vault (or lag storage pit) located inside the Hot Bay (DOE/NV, 1983). All fuel cores were removed from the site in 1989. Since the conclusion of the SFDP in the late 1980s, the E-MAD Facility has been mostly inactive with the exception of Fluid Tech Inc., who occupied 
portions of the Cold Bay and office areas in the late 1990s. Fluid Tech's primary activities included decontamination of plutonium from a historic XF-90 airplane formerly located in Plutonium Valley of the NTS (Seals, 2004). Other activities included testing of microbial digestion of protective clothing (Geary, 2006). In addition to portions of the Cold Bay, Fluid Tech also used one of the trailers as an office/first-aid station.

\subsection{Previous Investigations}

In 1996, a radiological characterization and decontamination project at the E-MAD Facility was initiated to meet the schedule of a commercial tenant, Kistler Aerospace Corporation, who had plans to use the E-MAD Facility. In February 1997, however, the prospective tenant cancelled its request to occupy the facility, and the project was suspended after radiological characterization fieldwork was completed and before any decontamination activity was performed.

Details regarding the survey and sampling results from the facility can be found in the document Decontamination and Decommissioning Subproject Characterization Report for the E-MAD Decontamination Project (DOE/NV, 1998b). The evaluation of the survey results confirmed historical knowledge that the primary radiological contaminants are uranium (U) and associated fission products. The evaluation of the chemical analysis showed that the primary building materials do not contain chemical concentrations that would generate Resource Conservation and Recovery Act (RCRA) waste. The radiological survey data showed that the extent of contamination has several trends that generally hold true throughout the facility. Relatively high levels of contamination are present on horizontal surfaces such as ledges, brackets attached to walls, the top surfaces of machinery, and the top surfaces of light fixtures. Penetrations also contained relatively high levels of contamination. Typical penetrations were cracks in floors, floor drains, cracks in walls, recessed electrical junction boxes, and the subgrade workings of the railway turntables. Relatively high levels of contamination were also found on oily or greasy surfaces, such as the rollers for the shield doors, the rails for the bridge-mounted equipment, the monorails for the wall-mounted handling units, oily surfaces adjacent to the oil-filled observation windows, cables, and other lubricated machinery. Relatively little contamination was found on vertical and overhead surfaces, such as walls and ceilings. Table 2-1 provides the available maximum radiological measurements for various locations within Building 3900. 
Table 2-1

Available Maximum Radiological Measurements for the E-MAD Facility (Page 1 of 2)

\begin{tabular}{|c|c|c|c|c|c|c|}
\hline \multirow{3}{*}{ Location } & \multicolumn{4}{|c|}{ Maximum Net Results $\left(\mathrm{dpm} / 100 \mathrm{~cm}^{2}\right)$} & \multicolumn{2}{|c|}{ Maximum Net Results ( $\mu \mathrm{R} / \mathrm{hr}$ ) } \\
\hline & \multicolumn{2}{|c|}{ Removable } & \multicolumn{2}{|c|}{ Total } & \multirow{2}{*}{$\begin{array}{c}\text { Exposure } \\
\text { Rate at } 1 \mathrm{~cm}\end{array}$} & \multirow{2}{*}{$\begin{array}{l}\text { Exposure } \\
\text { Rate at } 1 \mathrm{~m}\end{array}$} \\
\hline & Alpha & Beta & Alpha & Beta & & \\
\hline Hot Bay Walls (Room 122) & 6,000 & 37,344 & 153,000 & 864,000 & 120 & 80 \\
\hline Hot Bay Ceiling (Room 122) & 1,371 & 17,675 & 6,800 & 84,400 & 18 & 18 \\
\hline Hot Bay Floor (Room 122) & 757 & 7,024 & 11,930 & $4,256,000$ & 1,600 & 190 \\
\hline Hot Bay Turntable, Subgrade (Room 122) & 42 & 434 & 7,560 & 600,000 & 2,000 & 1,900 \\
\hline Bridge-Mounted Overhead Positioning System (OPS) & 1,498 & 20,690 & 9,540 & 118,000 & 10 & 10 \\
\hline Bridge-Mounted Crane & 747 & 6,101 & 11,700 & 98,300 & 0 & 0 \\
\hline Hot Bay OPS Power Strip & 331 & 6,630 & 5,040 & 79,000 & 30 & 21 \\
\hline Wall-Mounted Handling Unit, North & 1,384 & 53,055 & 12,400 & 211,000 & 0 & 0 \\
\hline Wall-Mounted Handling Unit, South & 3,972 & 136,844 & 23,380 & $1,180,000$ & 0 & 0 \\
\hline Basement Tank Vault, Walls, Floor, and Tank & 11 & 152 & 4,230 & 232,000 & 0 & 0 \\
\hline Fuel Rod Cask Welding Pit & 7 & 367 & 79 & 1,475 & 0 & 0 \\
\hline Fuel Rod Storage Pits Ventilation & 20 & 319 & 61 & 1,558 & 14 & 14 \\
\hline Crane Maintenance Balcony Wall (Room 306) & 214 & 2,233 & 4,630 & 155,500 & 32 & 49 \\
\hline Crane Maintenance Balcony Ceiling (Room 306) & 520 & 4,593 & 6,280 & 115,000 & 19 & 14 \\
\hline Crane Maintenance Balcony Floor (Room 306) & 783 & 7,570 & 22,500 & 129,000 & 36 & 18 \\
\hline Crane Maintenance Balcony OPS Power Strips & 236 & 2,788 & 31,600 & 55,400 & 0 & 0 \\
\hline Transfer Tunnel Walls (Room 128) & 2,306 & 13,393 & 7,714 & 80,100 & 39.5 & 40.5 \\
\hline Transfer Tunnel Ceiling (Room 128) & 329 & 6,648 & 3,220 & 31,800 & 12 & 12 \\
\hline Transfer Tunnel Floor (Room 128) & 29 & 2,673 & 11,800 & 74,800 & 42 & 23 \\
\hline Transfer Tunnel Turntable, Subgrade & 30 & 481 & 31,600 & 74,700 & 1,500 & 1,700 \\
\hline Balcony Hot Change Room Walls (Room 305) & 5 & 59 & 105 & 1,529 & 17 & 16 \\
\hline Balcony Hot Change Room Ceiling/Ductwork (Room 305) & 2 & 25 & 49 & 1,553 & 10 & 10 \\
\hline Hallway, Hot Change Room/Balcony & 10 & 51 & 51 & 689 & 7 & 6.5 \\
\hline
\end{tabular}

\section{UNCONTROLLED When Printed}


Table 2-1

Available Maximum Radiological Measurements for the E-MAD Facility (Page 2 of 2)

\begin{tabular}{|c|c|c|c|c|c|c|}
\hline \multirow{3}{*}{ Location } & \multicolumn{4}{|c|}{ Maximum Net Results (dpm/100 $\mathrm{cm}^{2}$ ) } & \multicolumn{2}{|c|}{ Maximum Net Results ( $\mu \mathrm{R} / \mathrm{hr})$} \\
\hline & \multicolumn{2}{|c|}{ Removable } & \multicolumn{2}{|c|}{ Total } & \multirow{2}{*}{$\begin{array}{c}\text { Exposure } \\
\text { Rate at } 1 \mathrm{~cm}\end{array}$} & \multirow{2}{*}{$\begin{array}{c}\text { Exposure } \\
\text { Rate at } 1 \mathrm{~m}\end{array}$} \\
\hline & Alpha & Beta & Alpha & Beta & & \\
\hline North Hot Change Room Walls (Room 120) & 54 & 453 & 387 & 7,064 & 16 & 14 \\
\hline North Hot Change Room Ceiling (Room 120) & 62 & 500 & 700 & 4,116 & 10 & 10 \\
\hline North Hot Change Room Floor (Room 120) & 14 & 375 & 126 & 7,988 & 12 & 15 \\
\hline Hallway, Hot Change Room/Hot Bay & 5 & 51 & 175 & 1,641 & 7 & 7 \\
\hline Machinery Room (Room 121) & 17 & 90 & 358 & 3,338 & 12 & 12 \\
\hline Machinery Room (Room 401) & 19 & 366 & 42 & 1,045 & 8 & 8.5 \\
\hline Machinery Room (Room 307) & 19 & 163 & 552 & 2,436 & 14 & 11 \\
\hline Transfer Tunnel Ductwork, Exterior & 563 & 16,970 & 6,080 & 65,200 & 16 & 12 \\
\hline Hot Bay Ductwork, Interior & 192 & 7,073 & 1,080 & 46,900 & 16 & 15 \\
\hline Hot Bay Ductwork, Exterior & 777 & 10,277 & 14,200 & 165,000 & 38 & 19 \\
\hline Hot Bay Outflow Filter Housing & 440 & 3,232 & 7,890 & 163,000 & 20 & 19 \\
\hline Hot Bay Exhaust Blowers and North Stack & 8 & 360 & 88 & 964 & 4 & 0 \\
\hline
\end{tabular}

Source: DOE/NV, 1998b

$\mathrm{cm}=$ Centimeter

$\mathrm{dpm} / 100 \mathrm{~cm}^{2}=$ Disintegrations per minute per 100 square centimeters $\mathrm{m}=$ Meter

$\mu \mathrm{R} / \mathrm{hr}=$ Microroentgens per hour 
The NTS management and operating (M\&O) contractor collected soil and swipe samples at the E-MAD Facility in 2003. Seven bulk soil samples were collected (February 2003) and analyzed for beryllium. The results of the analyses ranged from 0.0628 parts per million (ppm) to $0.4630 \mathrm{ppm}$ (Spezialetti, 2007). Fifteen swipe samples were collected (September 2003) and analyzed for arsenic, beryllium, cadmium, chromium, and lead. The analytical results for arsenic ranged from 0.7 micrograms per 100 square centimeters $\left(\mu \mathrm{g} / 100 \mathrm{~cm}^{2}\right)$ to $5.0 \mu \mathrm{g} / 100 \mathrm{~cm}^{2}$. The analytical results for beryllium ranged from $0.0 \mu \mathrm{g} / 100 \mathrm{~cm}^{2}$ to $0.13 \mu \mathrm{g} / 100 \mathrm{~cm}^{2}$. The analytical results for cadmium ranged from $0.03 \mu \mathrm{g} / 100 \mathrm{~cm}^{2}$ to $9.3 \mu \mathrm{g} / 100 \mathrm{~cm}^{2}$. The analytical results for chromium ranged from $0.66 \mu \mathrm{g} / 100 \mathrm{~cm}^{2}$ to $1,800 \mu \mathrm{g} / 100 \mathrm{~cm}^{2}$. The analytical results for lead ranged from $2.0 \mu \mathrm{g} / 100 \mathrm{~cm}^{2}$ to $3,700 \mu \mathrm{g} / 100 \mathrm{~cm}^{2}$ (Spezialetti, 2007). Specific sample locations for the 2003 data are unknown, and the results can only be used to assess initial requirements for personnel protection.

Thirty-five CASs consisting of various types of environmental releases or housekeeping materials related to the historical operations of the E-MAD Facility have previously been investigated and closed under the FFACO: 28 CASs have been closed under the clean closure strategy (22 of which were housekeeping CASs); 6 CASs have been closed under the closure in place strategy (CASs 25-05-06 and 25-25-17 have since had their associated URs lifted); and 1 CAS (25-25-18) was closed under a corrective action of no further action. Since the URs for CAS 25-05-06 (CAU 262) and CAS 25-25-17 (CAU 398) were originally established, practices and procedures relating to the implementation of risk-based corrective actions (RBCAs) have changed. Therefore, these URs were re-evaluated against the current RBCA criteria as defined in the Industrial Sites Project Establishment of Final Action Levels (FALs) (NNSA/NSO, 2006). This re-evaluation consisted of comparing the original data (the basis for the URs) to risk-based FALs developed using the current Industrial Sites RBCA process. The re-evaluation resulted in a recommendation to remove the URs because contamination is not present at the CASs above the risk-based FALs. The potential to remove the other existing URs will be evaluated during the CAU $114 \mathrm{CAI}$ and in consultation with the stakeholders (NNSA/NSO and NDEP).

Figure 2-6 shows the locations of the previously investigated CASs by associated CAU number, and Table 2-2 lists the FFACO reports documenting the previous investigations and corrective actions. The corrective actions performed at each of these CASs were reviewed and evaluated to determine (1) the potential impacts of existing URs on the CAU 114 CAI, and (2) whether any component of 


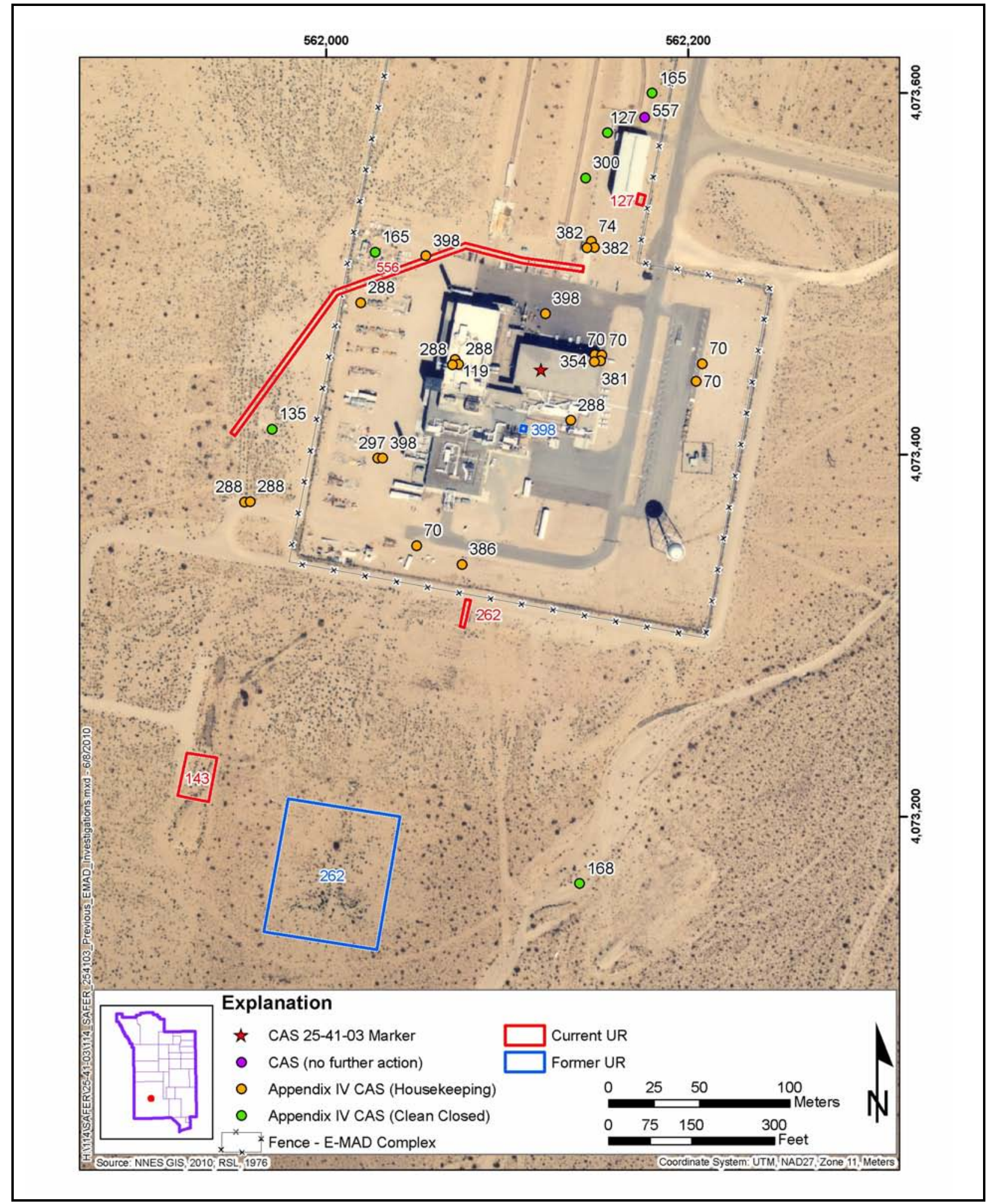

Figure 2-6

Previous Investigations Associated with E-MAD Facility Operations 
Table 2-2

Previous CAU Investigations Associated with the E-MAD Facility (Page 1 of 3 )

\begin{tabular}{|c|c|c|c|}
\hline CAU & CAS & $\begin{array}{c}\text { CAS } \\
\text { Description }\end{array}$ & Associated Documents \\
\hline \multicolumn{4}{|c|}{22 Housekeeping CASs Closed under the Clean Closure Strategy } \\
\hline \multirow{5}{*}{70} & $25-24-08$ & Batteries (2) & \multirow{5}{*}{$\begin{array}{l}\text { U.S. Department of Energy, Nevada Operations Office. 1995a. } \\
\text { Environmental Restoration Sites Inventory - Non-Hazardous Site } \\
\text { Cleanup Verification Summary. (DOE/NV, 1995a) }\end{array}$} \\
\hline & $25-24-10$ & Batteries (6) & \\
\hline & $25-26-11$ & Lead Bricks (30) & \\
\hline & $25-26-12$ & Lead Bricks (339) & \\
\hline & $25-26-20$ & Lead Bricks (52) & \\
\hline 74 & $25-29-10$ & $\begin{array}{l}\text { Chemicals (paint } \\
\text { and oil) }\end{array}$ & $\begin{array}{l}\text { U.S. Department of Energy, Nevada Operations Office. 1995b. } \\
\text { Environmental Restoration Sites Inventory - Site Cleanup Verification } \\
\text { Summary. (DOE/NV, 1995b) }\end{array}$ \\
\hline 119 & $25-01-14$ & $\begin{array}{l}\text { Contaminated } \\
\text { Storage Tank }\end{array}$ & $\begin{array}{l}\text { U.S. Department of Energy, Nevada Operations Office. 2000a. } \\
\text { Housekeeping Closure Report for Corrective Action Unit 119: } \\
\text { Storage Tanks, Nevada Test Site, Nevada, Rev. 0, DOE/NV--626. } \\
\text { (DOE/NV, 2000a) }\end{array}$ \\
\hline \multirow{6}{*}{288} & $25-23-04$ & $\begin{array}{l}\text { Radioactively } \\
\text { Contaminated } \\
\text { Crates }\end{array}$ & \multirow{6}{*}{$\begin{array}{l}\text { U.S. Department of Energy, Nevada Operations Office. 2000b. } \\
\text { Housekeeping Closure Report for Corrective Action Unit 288: Area } 25 \\
\text { Engine-Maintenance, Assembly, and Disassembly/Treatability Test } \\
\text { Facility Chemical Sites, Nevada Test Site, Nevada, Rev. 0, } \\
\text { DOE/NV--590. (DOE/NV, 2000b) }\end{array}$} \\
\hline & $25-23-10$ & $\begin{array}{l}\text { Contaminated } \\
\text { Materials }\end{array}$ & \\
\hline & $25-29-01$ & $\begin{array}{l}\text { Miscellaneous } \\
\text { Chemicals }\end{array}$ & \\
\hline & $25-29-04$ & $\begin{array}{l}\text { Miscellaneous } \\
\text { Chemicals }\end{array}$ & \\
\hline & $25-29-07$ & Ethylene Glycol & \\
\hline & $25-29-09$ & $\begin{array}{l}\text { Miscellaneous } \\
\text { Chemicals }\end{array}$ & \\
\hline 297 & $25-25-01$ & $\begin{array}{l}\text { Vacuum Pump Oil } \\
\text { Recovery }\end{array}$ & $\begin{array}{l}\text { U.S. Department of Energy, Nevada Operations Office. 1999a. } \\
\text { Closure Report for Housekeeping Category Corrective Action Unit 297: } \\
\text { Nevada Test Site, Nevada, Rev. 0, DOE/NV/11718--289. } \\
\text { (DOE/NV, 1999a) }\end{array}$ \\
\hline 354 & $25-99-15$ & $\begin{array}{l}\text { Highway Flares } \\
\text { (fuses) }\end{array}$ & $\begin{array}{l}\text { U.S. Department of Energy, Nevada Operations Office. 1998a. } \\
\text { Closure Report for Housekeeping Category Corrective Action Unit 354: } \\
\text { Nevada Test Site, Rev. 0, DOE/NV/11718--169. (DOE/NV, 1998a) }\end{array}$ \\
\hline 381 & $25-99-14$ & Gas Cylinders (2) & $\begin{array}{l}\text { U.S. Department of Energy, Nevada Operations Office. 1996a. } \\
\text { Corrective Action Unit } 381 \text { Gas Cylinder Closure Report, } \\
\text { 07-CAU381-002. (DOE/NV, 1996a) }\end{array}$ \\
\hline \multirow[b]{2}{*}{382} & $25-22-14$ & Drums (2) & \multirow{2}{*}{$\begin{array}{l}\text { U.S. Department of Energy, Nevada Operations Office. 1996b. } \\
\text { Corrective Action Unit } 382 \text { Housekeeping Closure Report. } \\
\text { (DOE/NV, 1996b) }\end{array}$} \\
\hline & $25-22-15$ & Drum & \\
\hline 386 & $25-26-24$ & Lead Bricks & $\begin{array}{l}\text { U.S. Department of Energy, Nevada Operations Office. } 1997 . \\
\text { Closure Report for Housekeeping Category Corrective Action Unit 386, } \\
\text { Nevada Test Site, Rev. 1, DOE/NV/11718--129. (DOE/NV, 1997) }\end{array}$ \\
\hline
\end{tabular}


Table 2-2

Previous CAU Investigations Associated with the E-MAD Facility (Page 2 of 3)

\begin{tabular}{|c|c|c|c|}
\hline CAU & CAS & $\begin{array}{c}\text { CAS } \\
\text { Description }\end{array}$ & Associated Documents \\
\hline \multirow[b]{3}{*}{398} & $25-25-02$ & Oil Spills & \multirow{3}{*}{$\begin{array}{l}\text { U.S. Department of Energy, National Nuclear Security Administration } \\
\text { Nevada Site Office. 2003b. Closure Report for Corrective Action } \\
\text { Unit 398: Area } 25 \text { Spill Sites, Nevada Test Site, Nevada, Rev. 1, } \\
\text { DOE/NV--873-REV 1. (NNSA/NSO, 2003b) } \\
\quad \text {-and- } \\
\text { U.S. Department of Energy, National Nuclear Security Administration } \\
\text { Nevada Site Office. 2008b. Addendum to the Closure Report for } \\
\text { Corrective Action Unit 398: Area } 25 \text { Spill Sites, Nevada Test Site, } \\
\text { Nevada, Rev. 0, DOE/NV--873-REV 1-ADD. (NNSA/NSO, 2008b) }\end{array}$} \\
\hline & $25-25-04$ & Oil Spills & \\
\hline & $25-25-05$ & Oil Spills & \\
\hline \multicolumn{4}{|c|}{6 Additional CASs Closed under the Clean Closure Strategy } \\
\hline 127 & $25-01-06$ & $\begin{array}{l}\text { Aboveground } \\
\text { Storage } \\
\text { Tank }\end{array}$ & $\begin{array}{l}\text { U.S. Department of Energy, National Nuclear Security Administration } \\
\text { Nevada Site Office. 2008c. Closure Report for Corrective Action } \\
\text { Unit 127: Areas } 25 \text { and } 26 \text { Storage Tanks, Nevada Test Site, Nevada, } \\
\text { Rev. 0, DOE/NV--1248. (NNSA/NSO, 2008c) }\end{array}$ \\
\hline 135 & $25-02-01$ & $\begin{array}{l}\text { Underground } \\
\text { Storage } \\
\text { Tank }\end{array}$ & $\begin{array}{l}\text { U.S. Department of Energy, National Nuclear Security Administration } \\
\text { Nevada Operations Office. 2001. Closure Report for Corrective Action } \\
\text { Unit 135: Areas } 25 \text { Underground Storage Tanks, Nevada Test Site, } \\
\text { Nevada, Rev. 1, DOE/NV--717-Rev. 1. (NNSA/NV, 2001) }\end{array}$ \\
\hline \multirow[t]{2}{*}{165} & 25-07-06 & $\begin{array}{l}\text { Train } \\
\text { Decontamination } \\
\text { Area }\end{array}$ & \multirow{2}{*}{$\begin{array}{l}\text { U.S. Department of Energy, National Nuclear Security Administration } \\
\text { Nevada Site Office. } 2005 \text {. Closure Report for Corrective Action } \\
\text { Unit 165: Area } 25 \text { and } 26 \text { Dry Well and Washdown Areas, Nevada Test } \\
\text { Site, Nevada, Rev. 0, DOE/NV--1092. (NNSA/NSO, 2005) }\end{array}$} \\
\hline & $25-59-01$ & Septic System & \\
\hline 168 & $25-16-01$ & $\begin{array}{l}\text { Construction } \\
\text { Waste } \\
\text { Pile }\end{array}$ & $\begin{array}{l}\text { U.S. Department of Energy, National Nuclear Security Administration } \\
\text { Nevada Site Office. } 2007 \text { a. Closure Report for Corrective Action } \\
\text { Unit 168: Area } 25 \text { and } 26 \text { Contaminated Materials and Waste } \\
\text { Dumps, Nevada Test Site, Nevada, Rev. 0, DOE/NV--1178. } \\
\text { (NNSA/NSO, 2007a) }\end{array}$ \\
\hline 300 & $25-60-02$ & $\begin{array}{l}\text { Building } 3901 \\
\text { Outfall }\end{array}$ & $\begin{array}{l}\text { U.S. Department of Energy, National Nuclear Security Administration } \\
\text { Nevada Site Office. 2007b. Closure Report for Corrective Action } \\
\text { Unit 300: Surface Release Areas, Nevada Test Site, Nevada, Rev. 0, } \\
\text { DOE/NV--1222. (NNSA/NSO, 2007b) }\end{array}$ \\
\hline \multicolumn{4}{|c|}{4 CASs Closed under the Closure in Place Strategy with URs } \\
\hline 127 & $25-01-07$ & $\begin{array}{l}\text { Aboveground } \\
\text { Storage } \\
\text { Tank }\end{array}$ & $\begin{array}{l}\text { U.S. Department of Energy, National Nuclear Security Administration } \\
\text { Nevada Site Office. 2008c. Closure Report for Corrective Action } \\
\text { Unit 127: Areas } 25 \text { and } 26 \text { Storage Tanks, Nevada Test Site, Nevada, } \\
\text { Rev. 0, DOE/NV--1248. (NNSA/NSO, 2008c) }\end{array}$ \\
\hline
\end{tabular}


Table 2-2

\section{Previous CAU Investigations Associated with the E-MAD Facility} (Page 3 of 3)

\begin{tabular}{|c|c|c|c|}
\hline CAU & CAS & $\begin{array}{c}\text { CAS } \\
\text { Description }\end{array}$ & Associated Documents \\
\hline 262 & $25-02-06$ & $\begin{array}{l}\text { Underground } \\
\text { Storage } \\
\text { Tank }\end{array}$ & $\begin{array}{l}\text { U.S. Department of Energy, National Nuclear Security Administration } \\
\text { Nevada Site Office. 2003a. Closure Report for Corrective Action } \\
\text { Unit 262: Area } 25 \text { Septic Systems and Underground Discharge Point, } \\
\text { Nevada Test Site, Nevada, Rev. 1, DOE/NV--897-REV 1. } \\
\text { (NNSA/NSO, 2003a) } \\
\text {-and- } \\
\text { U.S. Department of Energy, National Nuclear Security Administration } \\
\text { Nevada Site Office. 2008a. Addendum to the Closure Report for } \\
\text { Corrective Action Unit 262: Area } 25 \text { Septic Systems and Underground } \\
\text { Discharge Point, Nevada Test Site, Nevada, Rev. 0, } \\
\text { DOE/NV--897-REV 1-ADD. (NNSA/NSO, 2008a) }\end{array}$ \\
\hline 143 & $25-23-03$ & $\begin{array}{l}\text { Contaminated } \\
\text { Waste Dump \#2 }\end{array}$ & $\begin{array}{l}\text { U.S. Department of Energy, National Nuclear Security Administration } \\
\text { Nevada Operations Office. 2002a. Closure Report for Corrective } \\
\text { Action Unit 143: Area } 25 \text { Contaminated Waste Dumps, Nevada Test } \\
\text { Site, Nevada, Rev. 0, DOE/NV--807. (NNSA/NV, 2002a) }\end{array}$ \\
\hline 556 & $25-60-03$ & $\begin{array}{c}\text { E-MAD Stormwater } \\
\text { Discharge and } \\
\text { Piping }\end{array}$ & $\begin{array}{l}\text { U.S. Department of Energy, National Nuclear Security Administration } \\
\text { Nevada Site Office. 2008d. Corrective Action Decision } \\
\text { Document/Closure Report for Corrective Action Unit 556: Dry Wells } \\
\text { and Surface Release Points, Nevada Test Site, Nevada, Rev. 0, } \\
\text { DOE/NV--1285. (NNSA/NV, 2008d) }\end{array}$ \\
\hline \multicolumn{4}{|c|}{1 CAS No Further Action } \\
\hline 557 & $25-25-18$ & $\begin{array}{l}\text { Train Maintenance } \\
\text { Building } 3901 \\
\text { Spill Site }\end{array}$ & $\begin{array}{l}\text { U.S. Department of Energy, National Nuclear Security Administration } \\
\text { Nevada Site Office. 2009a. Corrective Action Decision } \\
\text { Document/Closure Report for Corrective Action Unit 557: Spills and } \\
\text { Tank Sites, Nevada Test Site, Nevada, Rev. 0, DOE/NV--1319. } \\
\text { (NNSA/NSO, 2009a) }\end{array}$ \\
\hline \multicolumn{4}{|c|}{2 CASs with URs Removed } \\
\hline 262 & $25-05-06$ & Leachfield & $\begin{array}{l}\text { U.S. Department of Energy, National Nuclear Security Administration } \\
\text { Nevada Site Office. 2003a. Closure Report for Corrective Action } \\
\text { Unit 262: Area } 25 \text { Septic Systems and Underground Discharge Point, } \\
\text { Nevada Test Site, Nevada, Rev. 1, DOE/NV--897-REV 1. } \\
\text { (NNSA/NSO, 2003a) } \\
\text {-and- } \\
\text { U.S. Department of Energy, National Nuclear Security Administration } \\
\text { Nevada Site Office. 2008a. Addendum to the Closure Report for } \\
\text { Corrective Action Unit 262: Area } 25 \text { Septic Systems and Underground } \\
\text { Discharge Point, Nevada Test Site, Nevada, Rev. 0, } \\
\text { DOE/NV--897-REV 1-ADD. (NNSA/NSO, 2008a) }\end{array}$ \\
\hline 398 & $25-25-17$ & $\begin{array}{l}\text { Subsurface } \\
\text { Hydraulic Oil Spill }\end{array}$ & $\begin{array}{l}\text { U.S. Department of Energy, National Nuclear Security Administration } \\
\text { Nevada Site Office. 2003b. Closure Report for Corrective Action } \\
\text { Unit 398: Area 25 Spill Sites, Nevada Test Site, Nevada, Rev. 1, } \\
\text { DOE/NV--873-REV 1. (NNSA/NSO, 2003b) } \\
\quad \text {-and- } \\
\text { U.S. Department of Energy, National Nuclear Security Administration } \\
\text { Nevada Site Office. 2008b. Addendum to the Closure Report for } \\
\text { Corrective Action Unit 398: Area 25 Spill Sites, Nevada Test Site, } \\
\text { Nevada, Rev. 0, DOE/NV--873-REV 1-ADD. (NNSA/NSO, 2008b) }\end{array}$ \\
\hline
\end{tabular}


the CAS was not addressed, and therefore should be included in the scope of CAU 114. Although CAS 25-01-14 (CAU 119) is located within the footprint of the E-MAD Facility, it is not believed to have any impact on CAS 25-41-03. Corrective Action Site 25-01-14 was clean closed under the housekeeping corrective action process (DOE/NV, 2000a).

\subsubsection{Potential Impacts of Existing Use Restrictions to the CAU 114 CAI}

\section{CAU 127: CAS 25-01-07, Aboveground Storage Tank}

This site, located next to the ETSM Building (Building 3901), consisted of releases associated with a 1,000-gal aboveground storage tank (AST), associated piping, and total petroleum hydrocarbons (TPH)-impacted soil. Approximately $20 \mathrm{yd}^{3}$ of TPH-impacted soil were excavated to a depth of approximately $5 \mathrm{ft}$ as part of the corrective action. The AST, piping, and concrete pad were removed for disposal. Due to the close proximity of the AST to the ETSM Building and the fact that the impacted soil may extend under its structure, the remaining impacted soil was not excavated and was closed in place with administrative controls. A UR for TPH was implemented to prohibit unauthorized intrusive activity, and UR warning signs were posted.

This UR is not expected to have any impact on CAU 114 due to the location of the UR away from any planned CAU 114 CAI activities.

\section{CAU 262: CAS 25-02-06, Underground Storage Tank}

This site consisted of the releases associated with a septic system that received sanitary effluent from Building 3900. The septic tank was found to contain TPH and polychlorinated biphenyls (PCBs) above action levels. These COCs were confined within the septic tank, and a UR was implemented as the boundary of the tank itself. This CAS was closed in place by solidifying the tank contents, and by filling the tank, distribution box, and one upstream access point (manhole) with grout.

This UR is not expected to have any impact on CAU 114 due to the location of the UR outside of the perimeter fence and away from any planned CAU 114 CAI activities.

\section{CAU 143: CAS 25-23-03, Contaminated Waste Dump \#2}

This site consisted of the releases associated with a waste dump (in the form of a trench) that was generated during operation of the E-MAD Facility. Sampling of the waste dump identified 
radionuclides above FALs including uranium (U)-235, cesium (Cs)-137, niobium (Nb)-94, and strontium (Sr)-90. A UR was subsequently implemented for subsurface radioactive contamination. The existing fence was modified to include a separate enclosure for only the filled portion of the trench that contains contamination. The fence was posted as "Caution-Underground Radioactive Material” area. The trench is located approximately 1/4 mile southwest of Building 3900 and lies about 200 yards beyond the E-MAD Facility perimeter fence.

This UR is not expected to have any impact on CAU 114 due to the location of the UR outside of the perimeter fence and away from any planned CAU 114 CAI activities.

\section{CAU 556: CAS 25-60-03, EMAD Stormwater Discharge and Piping}

This site consisted of the releases associated with three catch basins, an outfall area, and associated subsurface piping. Sampling results identified PCB contamination above the FAL in the surface and/or shallow subsurface soils around Catch Basin 2, at the outfall, and in soils contained within the catch basins and a manhole. The CAS was closed in place with a corrective action of soil removal; grouting of the catch basins, manholes, and pipe openings; and implementation of a UR for PCB contamination that prohibits surface and subsurface disturbances within $5 \mathrm{ft}$ laterally of the center line of the stormwater drainage system. The UR is located approximately $100 \mathrm{ft}$ north of Building 3900 and extends the width of the north side of Building 3900, angles southwest, and ends beyond the perimeter fencing.

This UR is not expected to impact CAI activities at CAU 114; however, there is a possibility that surface soil contamination that overlaps the spatial boundaries of this UR may be identified if biasing factors are present in this area. If evidence of a release is identified within the boundaries of the UR, NNSA/NSO will be informed to provide approval to work within the UR. 


\subsection{Data Quality Objectives}

\subsection{Summary of DQO Analysis}

This section contains a summary of the DQO process that is presented in Appendix B. The DQO process is a strategic planning approach based on the scientific method that is designed to ensure that the data collected will provide sufficient and reliable information to identify, evaluate, and technically defend the recommendation of viable corrective actions (e.g., no further action, clean closure, or closure in place).

The DQO strategy for CAU 114 was developed at a meeting on April 30, 2009. The DQOs were developed to identify data needs, clearly define the intended use of the environmental data, and to design a data collection program that will satisfy these purposes. During the DQO discussions for this CAU, the informational inputs or data needs to resolve problem statements and decision statements were documented.

The problem statement for CAU 114 is: "Existing information on the nature and extent of potential contamination is insufficient to validate the assumptions used to select the corrective actions or to verify that closure objectives were met for the CAS in CAU 114.” To address this question, the resolution of two decisions statements is required:

- Decision I: "Is any waste present at the site likely to result in the introduction of COCs into site environmental media?” For the judgmental sampling design, any analytical result for a waste sample exceeding PSM criteria will result in that waste being designated as a PSM.

- Decision II: “Is sufficient information available to confirm that closure objectives were met?” Sufficient information is defined to include:

- The information needed to characterize investigation-derived waste (IDW) for disposal

- The information needed to determine remediation waste types

The presence of a COC would require a corrective action. A corrective action may also be necessary if there is a potential for wastes that are present at a site to result in the introduction of COCs into site environmental media. These wastes would be considered PSM, which is defined as waste (solid or liquid) containing contaminants that, if released to soil, would result in soil contamination exceeding 
a FAL. To determine whether wastes that are present at CAU 114 meet the criteria for PSM, the following conservative assumptions were made:

- Any containment of waste (e.g., fuel/oil reservoirs, pipe, concrete vaults and walls, drums) would fail at some point, and the waste would be released to the surrounding soil.

- A waste, regardless of concentration or configuration, may be assumed to be PSM and handled under a corrective action.

- Based on process knowledge and/or professional judgment, some waste may be assumed to not be PSM if it is clear that it could not result in soil contamination exceeding a FAL.

- If assumptions about the waste cannot be made, then the waste material will be sampled, and the results will be compared to FALs based on the following criteria:

- For non-liquid wastes, the concentration of any chemical contaminant in soil (following degradation of the waste and release of contaminants into soil) would be equal to the mass of the contaminant in the waste divided by the mass of the waste (no consideration will be given to dilution into the mass of soil).

- For non-liquid wastes, the dose resulting from radioactive contaminants in soil (following degradation of the waste and release of contaminants into soil) would be calculated using the activity of the contaminant in the waste divided by the mass of the waste (for each radioactive contaminant) and calculating the combined resulting dose using the Residual Radioactive (RESRAD) code (Murphy, 2004) (no consideration will be given to dilution into the mass of soil). Note: As an initial screening tool, if building materials are primarily externally contaminated and do not present a dose exceeding the FAL to a nearby worker in its current configuration, it will not be considered to meet PSM criteria.

- For liquid wastes, the resulting concentration of contaminants in the surrounding soil would be calculated based on the concentration of contaminants in the wastes and the liquid holding capacity of the soil.

For example, sludge containing a contaminant exceeding an equivalent FAL concentration would be considered to be PSM and would require a corrective action. Ballasts with capacitors are assumed to contain PCBs based on process knowledge. These ballasts/capacitors would be assumed to be PSM without sampling and would require a corrective action. (See Table 4-2 for a list of known or anticipated PSMs associated with CAU 114.) It is possible that de minimis amounts of these materials (e.g., lead shot in walls, lead solder) may remain after corrective actions as described in Section 1.2. 
Decision I samples will be submitted to analytical laboratories for the analyses listed in Table 3-1. The constituents reported for each analytical method are listed in Table 3-2.

Table 3-1

Analytical Program ${ }^{a}$

\begin{tabular}{|c|c|}
\hline Analyses & $\begin{array}{l}\text { CAS 25-41-03 } \\
\text { EMAD Facility }\end{array}$ \\
\hline \multicolumn{2}{|c|}{ Organic COPCs } \\
\hline TPH-DRO & $\mathrm{X}$ \\
\hline PCBs & $x$ \\
\hline SVOCs & $x$ \\
\hline VOCs & $x$ \\
\hline Pesticides & $x$ \\
\hline \multicolumn{2}{|c|}{ Inorganic COPCs } \\
\hline RCRA Metals & $\bar{x}$ \\
\hline Total Beryllium & $x$ \\
\hline \multicolumn{2}{|c|}{ Radionuclide COPCs } \\
\hline Gamma Spectroscopy & $\mathrm{X}$ \\
\hline Isotopic U & $x$ \\
\hline Isotopic Pu & $x$ \\
\hline Sr-90 & $X$ \\
\hline
\end{tabular}

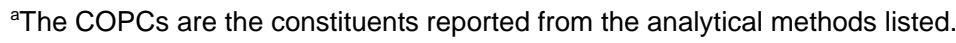

DRO = Diesel-range organics

SVOC $=$ Semivolatile organic compound

VOC $=$ Volatile organic compound

$\mathrm{X}=$ Required analytical method

The list of COPCs is intended to encompass all of the contaminants that could potentially be present at the CAS (or its components). These COPCs were identified during the planning process through the review of site history, process knowledge, personal interviews, past investigation efforts (where available), and inferred activities associated with the CAS. Contaminants detected at other similar NTS sites were also included in the COPC list to reduce the uncertainty about potential contamination at the CAS because complete information regarding activities performed at the E-MAD Facility is not available. 
Table 3-2

Constituents Reported by Analytical Methods

\begin{tabular}{|c|c|c|c|c|c|c|c|c|}
\hline \multicolumn{2}{|c|}{ VOCs } & \multicolumn{2}{|c|}{ SVOCs } & TPH & PCBs & Pesticides & Metals & Radionuclides \\
\hline $\begin{array}{l}\text { 1,1,1,2-Tetrachloroethane } \\
\text { 1,1,1-Trichloroethane } \\
\text { 1,1,2,2-Tetrachloroethane } \\
\text { 1,1,2-Trichloroethane } \\
\text { 1,1-Dichloroethane } \\
\text { 1,1-Dichloroethene } \\
\text { 1,2,4-Trichlorobenzene } \\
\text { 1,2,4-Trimethylbenzene } \\
\text { 1,2-Dibromo-3-chloropropane } \\
\text { 1,2-Dichlorobenzene } \\
\text { 1,2-Dichloroethane } \\
\text { 1,2-Dichloropropane } \\
\text { 1,3,5-Trimethylbenzene } \\
\text { 1,3-Dichlorobenzene } \\
\text { 1,4-Dichlorobenzene } \\
\text { 1,4-Dioxane } \\
\text { 2-Butanone } \\
\text { 2-Chlorotoluene } \\
\text { 2-Hexanone } \\
\text { 4-isopropyltoluene } \\
\text { 4-Methyl-2-pentanone } \\
\text { Acetone } \\
\text { Acetonitrile } \\
\text { Allyl chloride } \\
\text { Benzene } \\
\text { Bromodichloromethane } \\
\text { Bromoform } \\
\text { Bromomethane } \\
\text { Carbon disulfide }\end{array}$ & $\begin{array}{l}\text { Carbon tetrachloride } \\
\text { Chlorobenzene } \\
\text { Chloroethane } \\
\text { Chloroform } \\
\text { Chloromethane } \\
\text { Chloroprene } \\
\text { cis-1,2-Dichloroethene } \\
\text { Dibromochloromethane } \\
\text { Dichlorodifluoromethane } \\
\text { Ethyl methacrylate } \\
\text { Ethylbenzene } \\
\text { Isobutyl alcohol } \\
\text { Isopropylbenzene } \\
\text { Methacrylonitrile } \\
\text { Methyl methacrylate } \\
\text { Methylene chloride } \\
\text { n-Butylbenzene } \\
\text { n-Propylbenzene } \\
\text { sec-Butylbenzene } \\
\text { Styrene } \\
\text { tert-Butylbenzene } \\
\text { Tetrachloroethene } \\
\text { Toluene } \\
\text { Total Xylenes } \\
\text { Trichloroethene } \\
\text { Trichlorofluoromethane } \\
\text { Vinyl acetate } \\
\text { Vinyl chloride }\end{array}$ & $\begin{array}{l}\text { 2,3,4,6-Tetrachlorophenol } \\
\text { 2,4,5-Trichlorophenol } \\
\text { 2,4,6-Trichlorophenol } \\
\text { 2,4-Dimethylphenol } \\
\text { 2,4-Dinitrotoluene } \\
\text { 2-Chlorophenol } \\
\text { 2-Methylnaphthalene } \\
\text { 2-Methylphenol } \\
\text { 2-Nitrophenol } \\
\text { 3-Methylphenol } \text { (m-cresol) }^{\text {4-Methylphenol }} \text { (p-cresol) } \\
\text { 4-Chloroaniline } \\
\text { 4-Nitrophenol } \\
\text { Acenaphthene } \\
\text { Acenaphthylene } \\
\text { Aniline } \\
\text { Anthracene } \\
\text { Benzo(a)anthracene } \\
\text { Benzo(a)pyrene } \\
\text { Benzo(b)fluoranthene } \\
\text { Benzo(g,h,i)perylene } \\
\text { Benzo(k)fluoranthene } \\
\text { Benzoic Acid } \\
\text { Benzyl Alcohol } \\
\text { Bis(2-ethylhexyl) phthalate } \\
\text { Butyl benzyl phthalate } \\
\text { Carbazole } \\
\text { Chrysene } \\
\text { Di-n-butyl Phthalate }\end{array}$ & $\begin{array}{l}\text { Di-n-octyl Phthalate } \\
\text { Dibenzo(a,h)anthracene } \\
\text { Dibenzofuran } \\
\text { Diethyl Phthalate } \\
\text { Dimethyl Phthalate } \\
\text { Fluoranthene } \\
\text { Fluorene } \\
\text { Hexachlorobenzene } \\
\text { Hexachlorobutadiene } \\
\text { Hexachloroethane } \\
\text { Indeno(1,2,3-cd)pyrene } \\
\text { n-Nitroso-di-n-propylamine } \\
\text { Naphthalene } \\
\text { Nitrobenzene } \\
\text { Pentachlorophenol } \\
\text { Phenanthrene } \\
\text { Phenol } \\
\text { Pyrene } \\
\text { Pyridine }\end{array}$ & DRO & $\begin{array}{l}\text { Aroclor } 1016 \\
\text { Aroclor } 1221 \\
\text { Aroclor } 1232 \\
\text { Aroclor } 1242 \\
\text { Aroclor } 1248 \\
\text { Aroclor } 1254 \\
\text { Aroclor } 1260 \\
\text { Aroclor } 1268\end{array}$ & $\begin{array}{l}\text { 4,4'-DDD } \\
4,4 \text { '-DDE } \\
\text { 4,4'-DDT } \\
\text { Aldrin } \\
\text { Alpha-BHC } \\
\text { Alpha-Chlordane } \\
\text { Beta-BHC } \\
\text { Chlordane } \\
\text { Delta-BHC } \\
\text { Dieldrin } \\
\text { Endosulfan I } \\
\text { Endosulfan II } \\
\text { Endosulfan Sulfate } \\
\text { Endrin } \\
\text { Endrin Aldehyde } \\
\text { Endrin Ketone } \\
\text { Gamma-BHC } \\
\text { Gamma-Chlordane } \\
\text { Heptachlor } \\
\text { Heptachlor Epoxide } \\
\text { Methoxychlor } \\
\text { Toxaphene }\end{array}$ & $\begin{array}{l}\text { Arsenic } \\
\text { Barium } \\
\text { Beryllium } \\
\text { Cadmium } \\
\text { Chromium } \\
\text { Lead } \\
\text { Mercury } \\
\text { Selenium } \\
\text { Silver }\end{array}$ & $\begin{array}{l}\text { Gamma-Emitting } \\
\text { Ac-228 } \\
\text { Am-241 } \\
\text { Co-60 } \\
\text { Cs-137 } \\
\text { Eu-152 } \\
\text { Eu-154 } \\
\text { Eu-155 } \\
\text { K-40 } \\
\text { Nb-94 } \\
\mathrm{Pb}-212 \\
\mathrm{~Pb}-214 \\
\text { Tl-208 } \\
\text { Th-234 } \\
\text { U-235 }\end{array}$ \\
\hline
\end{tabular}

May be reported as 3,4-Methylphenol or m,p-cresol.

$\begin{array}{ll}\mathrm{Ac}=\text { Actinium } & \mathrm{Pb}=\text { Lead } \\ \mathrm{Am}=\text { Americium } & \mathrm{Pu}=\text { Plutonium } \\ \mathrm{Co}=\text { Cobalt } & \mathrm{Th}=\text { Thorium } \\ \text { Eu = Europium } & \mathrm{Tl}=\text { Thallium } \\ \mathrm{K}=\text { Potassium } & \end{array}$

$\begin{array}{ll}\mathrm{Co}=\text { Cobalt } & \mathrm{Th}=\text { Thorium } \\ \mathrm{Eu}=\text { Europium } & \mathrm{Tl}=\text { Thallium } \\ \mathrm{K}=\text { Potassium } & \end{array}$

Potassium 
The data quality indicators (DQIs) of precision, accuracy, representativeness, completeness, comparability, and sensitivity needed to satisfy DQO requirements are discussed in Section 7.2. Laboratory data will be assessed in the CR to confirm or refute the CSM and determine whether the DQO data needs were met.

To satisfy the DQI of sensitivity (presented in Section 7.2.6), the analytical methods must be sufficient to detect contamination that is present in the samples at concentrations equal to the corresponding FALs. Analytical methods and minimum detectable concentrations (MDCs) for each CAU 114 COPC are provided in Tables 3-3 and 3-4. The MDC is the lowest concentration of a chemical or radionuclide parameter that can be detected in a sample within an acceptable level of error. The criteria for precision and accuracy in Tables 3-3 and 3-4 may vary from information in the Industrial Sites Quality Assurance Project Plan (QAPP) as a result of the laboratory being used, or updated/new methods used by the laboratory (NNSA/NV, 2002b).

Table 3-3 Analytical Requirements for Radiological COPCs for CAU 114 (Page 1 of 2)

\begin{tabular}{|c|c|c|c|c|c|}
\hline Analysis $^{a}$ & $\begin{array}{l}\text { Medium or } \\
\text { Matrix }\end{array}$ & $\begin{array}{c}\text { Analytical } \\
\text { Method }\end{array}$ & $\mathrm{MDC}^{\mathrm{b}}$ & $\begin{array}{l}\text { Laboratory } \\
\text { Precision }\end{array}$ & $\begin{array}{l}\text { Laboratory } \\
\text { Accuracy }\end{array}$ \\
\hline \multicolumn{6}{|c|}{ Gamma-Emitting Radionuclides } \\
\hline \multirow[b]{2}{*}{$\begin{array}{c}\text { Gamma } \\
\text { Spectroscopy }\end{array}$} & Aqueous & EPA $901.1^{c}$ & \multirow[b]{2}{*}{$<$ PALS } & \multirow{2}{*}{$\begin{array}{c}\text { RPD } \\
35 \% \text { (non-aqueous) }^{\mathrm{d}} \\
20 \% \text { (aqueous) }^{\mathrm{d}} \\
\mathrm{ND} \\
-2<\mathrm{ND}<2^{\mathrm{e}}\end{array}$} & \multirow[b]{2}{*}{$\begin{array}{c}\text { LCS Recovery } \\
(\% \mathrm{R}) \\
80-120^{f}\end{array}$} \\
\hline & Non-aqueous & HASL-300 & & & \\
\hline \multicolumn{6}{|c|}{ Other Radionuclides } \\
\hline Isotopic U & All & $\mathrm{U}-02-\mathrm{RC}^{\mathrm{g}}$ & \multirow{5}{*}{$<$ PALs } & \multirow{5}{*}{$\begin{array}{c}\text { RPD } \\
35 \% \\
\text { (non-aqueous) }^{d} \\
20 \% \text { (aqueous) }^{d}\end{array}$} & \multirow{5}{*}{$\begin{array}{c}\text { Chemical Yield } \\
\text { Recovery (\%R) } \\
30-105^{\mathrm{h}} \\
\text { LCS Recovery } \\
(\% \mathrm{R}) \\
80-120^{\mathrm{h}}\end{array}$} \\
\hline \multirow{2}{*}{ Isotopic Pu } & Aqueous & Pu-10-RC ${ }^{g}$ & & & \\
\hline & Non-aqueous & Pu-02-RC ${ }^{g}$ & & & \\
\hline \multirow{2}{*}{ Sr-90 } & Aqueous & EPA $905.0^{c}$ & & & \\
\hline & Non-aqueous & $\mathrm{Sr}-02-\mathrm{RC}^{\mathrm{g}}$ & & & \\
\hline
\end{tabular}


Table 3-3

Analytical Requirements for Radiological COPCs for CAU 114

(Page 2 of 2)

\begin{tabular}{|c|c|c|c|c|c|}
\hline Analysis $^{a}$ & $\begin{array}{c}\text { Medium or } \\
\text { Matrix }\end{array}$ & $\begin{array}{c}\text { Analytical } \\
\text { Method }\end{array}$ & MDC $^{\mathbf{b}}$ & $\begin{array}{c}\text { Laboratory } \\
\text { Precision }\end{array}$ & $\begin{array}{c}\text { Laboratory } \\
\text { Accuracy }\end{array}$ \\
\hline
\end{tabular}

${ }^{\mathrm{a} A}$ list of constituents reported for each method is provided in Table 3-2.

${ }^{\mathrm{b}}$ The MDC is the minimum concentration of a constituent that can be measured and reported with $95 \%$ confidence

(Standard Methods)'.

'Prescribed Procedures for Measurement of Radioactivity in Drinking Water (EPA, 1980).

'Sampling and Analysis Plan Guidance and Template (EPA, 2000).

${ }^{\mathrm{e}}$ Evaluation of Radiochemical Data Usability (Paar and Porterfield, 1997).

${ }^{\mathrm{f}}$ Test Methods for Evaluating Solid Waste, Physical/Chemical Methods (EPA, 2009b).

${ }^{9}$ The Procedures Manual of the Environmental Measurements Laboratory (DOE, 1997).

${ }^{\text {h}}$ Professional judgment and other industry acceptance criteria are used.

'Laboratory standard operating procedures in accordance with industry standards and the NNES Statement of Work requirements.

$\mathrm{EPA}=$ U.S. Environmental Protection Agency

LCS = Laboratory control sample

ND = Normalized difference

NNES = Navarro Nevada Environmental Services, LLC
$\mathrm{PAL}=$ Preliminary action level
$\mathrm{RPD}=$ Relative percent difference
$\% \mathrm{R}=$ Percent recovery

Table 3-4

Analytical Requirements for Chemical COPCs for CAU 114 (Page 1 of 2)

\begin{tabular}{|c|c|c|c|c|c|}
\hline Analysis $^{a}$ & $\begin{array}{l}\text { Medium or } \\
\text { Matrix }\end{array}$ & $\begin{array}{c}\text { Analytical } \\
\text { Method }\end{array}$ & $\mathrm{MDC}^{\mathrm{b}}$ & $\begin{array}{l}\text { Laboratory } \\
\text { Precision }\end{array}$ & $\begin{array}{c}\text { Laboratory } \\
\text { Accuracy }\end{array}$ \\
\hline \multicolumn{6}{|c|}{ Organics } \\
\hline VOCs & All & $8260^{c}$ & $<$ PALS & Lab-specific $^{d}$ & Lab-specific $^{d}$ \\
\hline SVOCs & All & $8270^{c}$ & $<$ PALS & Lab-specific $^{d}$ & Lab-specific $^{d}$ \\
\hline PCBs & All & $8082^{c}$ & \multirow{3}{*}{$<$ PALS } & Lab-specific $^{d}$ & Lab-specific $^{d}$ \\
\hline TPH-DRO & All & 8015 Modified $^{c}$ & & Lab-specific $^{d}$ & Lab-specific $^{d}$ \\
\hline Pesticides & All & $8081^{c}$ & & Lab-specific $^{d}$ & Lab-specific $^{d}$ \\
\hline \multicolumn{6}{|c|}{ Inorganics } \\
\hline Metals & All & $6010 / 6020^{c}$ & \multirow{3}{*}{$<$ PALS } & RPD & MS Recovery \\
\hline \multirow[b]{2}{*}{ Mercury } & Aqueous & $7470^{c}$ & & & $75-125^{c}$ \\
\hline & Non-aqueous & $7471^{c}$ & & $\begin{array}{l}\text { Absolute Difference } \\
\pm 2 \times \text { RL (non-aqueous) } \\
\quad \pm 1 \times \text { RL (aqueous) }\end{array}$ & $\begin{array}{c}\text { LCS Recovery } \\
(\% \mathrm{R}) \\
80-120^{\mathrm{c}}\end{array}$ \\
\hline
\end{tabular}


Table 3-4

Analytical Requirements for Chemical COPCs for CAU 114

(Page 2 of 2)

\begin{tabular}{|c|c|c|c|c|c|}
\hline Analysis $^{\mathbf{a}}$ & $\begin{array}{c}\text { Medium or } \\
\text { Matrix }\end{array}$ & $\begin{array}{c}\text { Analytical } \\
\text { Method }\end{array}$ & MDC $^{\mathbf{b}}$ & $\begin{array}{c}\text { Laboratory } \\
\text { Precision }\end{array}$ & $\begin{array}{c}\text { Laboratory } \\
\text { Accuracy }\end{array}$ \\
\hline
\end{tabular}

aA list of constituents reported for each method is provided in Table 3-2.

${ }^{\mathrm{b}}$ The MDC is the minimum concentration of a constituent that can be measured and reported with 99\% confidence (EPA, 2009b).

${ }^{\mathrm{c} T e s t}$ Methods for Evaluating Solid Waste, Physical/Chemical Methods (EPA, 2009b).

dPrecision and accuracy criteria are developed in-house using approved laboratory standard operating procedures in accordance with industry standards and the NNES Statement of Work requirements (NNES, 2009).

eSampling and Analysis Plan Guidance and Template (EPA, 2000).

'USEPA Contract Laboratory Program National Functional Guidelines for Inorganic Data Review (EPA, 2004).

MS = Matrix spike

$\mathrm{RL}=$ Reporting limit

\subsection{Results of the DQO Analysis}

\subsubsection{Action Level Determination and Basis}

The PALs presented in this section are to be used for site screening purposes. They are not necessarily intended to be used as cleanup action levels or FALs. However, they are useful in screening out contaminants that are not present in sufficient concentrations to warrant further evaluation, therefore streamlining the consideration of remedial alternatives. The RBCA process used to establish FALs is described in the Industrial Sites Project Establishment of Final Action Levels (NNSA/NSO, 2006). This process conforms with Nevada Administrative Code (NAC) Section 445A.227, which lists the requirements for sites with soil contamination (NAC, 2008a). For the evaluation of corrective actions, NAC Section 445A.22705 (NAC, 2008b) requires the use of American Society for Testing and Materials (ASTM) Method E1739 (ASTM, 1995) to "conduct an evaluation of the site, based on the risk it poses to public health and the environment, to determine the necessary remediation standards (i.e., FALs) or to establish that corrective action is not necessary.”

This RBCA process, summarized in Figure 3-1, defines three tiers (or levels) of evaluation involving increasingly sophisticated analyses:

- Tier 1 evaluation - sample results from source areas (highest concentrations) are compared to action levels based on generic (non-site-specific) conditions (i.e., the PALs established in this SAFER). The FALs may then be established as the Tier 1 action levels, or the FALs may be calculated using a Tier 2 evaluation. 


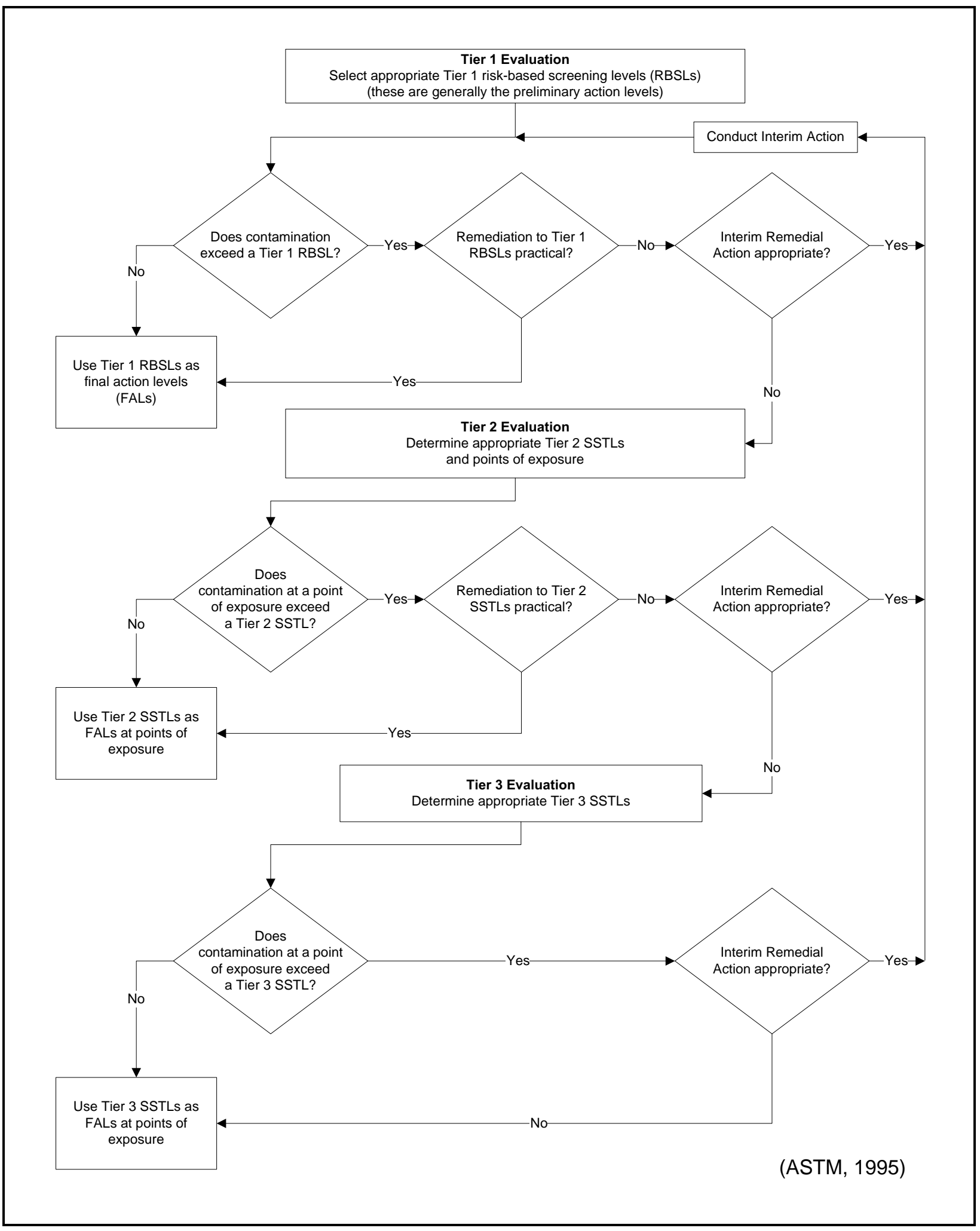

Figure 3-1

Risk-Based Corrective Action Decision Process 
- Tier 2 evaluation - conducted by calculating Tier 2 Site-Specific Target Levels (SSTLs) using site-specific information as inputs to the same or similar methodology used to calculate Tier 1 action levels. The Tier 2 SSTLs are then compared to individual sample results from reasonable points of exposure (as opposed to the source areas as is done in Tier 1) on a point-by-point basis. Total petroleum hydrocarbon concentrations will not be used for risk-based decisions under Tier 2 or Tier 3. Rather, the individual chemicals of concern will be compared to the SSTLs.

- Tier 3 evaluation - conducted by calculating Tier 3 SSTLs on the basis of more sophisticated risk analyses using methodologies described in Method E1739 that consider site-, pathway-, and receptor-specific parameters.

Evaluation of DQO decisions will be based on conditions at the site following completion of any corrective actions. Any corrective actions conducted will be reported in the CR.

The FALs (along with the basis for their selection) will be defined in the CR, where they will be compared to laboratory results in the evaluation of site closure.

\subsubsection{Chemical PALs}

Except as noted herein, the chemical PALs are defined as the EPA Region 9 Superfund preliminary regional screening levels (RSLs) for chemical contaminants in industrial soils (EPA, 2009a). Background concentrations for RCRA metals and zinc will be used instead of RSLs when natural background concentrations exceed the RSL, as is often the case with arsenic on the NTS. Background is considered the mean plus two standard deviations of the mean for sediment samples collected by the Nevada Bureau of Mines and Geology throughout the Nevada Test and Training Range (formerly the Nellis Air Force Range) (NBMG, 1998; Moore, 1999). For detected chemical COPCs without established RSLs, the protocol used by the EPA Region 9 in establishing RSLs (or similar) will be used to establish PALs (EPA, 2009a). If used, this process will be documented in the CR.

\subsubsection{Total Petroleum Hydrocarbon PALs}

The PAL for TPH is 100 milligrams per kilogram $(\mathrm{mg} / \mathrm{kg})$ as listed in NAC 445A.2272 (NAC, 2008c). 


\subsubsection{Radionuclide PALs}

The PALs for radiological contaminants are based on the National Council on Radiation Protection and Measurements (NCRP) Report No. 129 recommended screening limits for construction, commercial, and industrial land-use scenarios (NCRP, 1999) using a 25-millirem-per-year (mrem/yr) dose constraint (Murphy, 2004) and the generic guidelines for residual concentration of radionuclides in DOE Order 5400.5 (DOE, 1993). These PALs are based on the construction, commercial, and industrial land-use scenario provided in the guidance and are appropriate for the NTS based on future land uses presented in Section B.2.2.6.

\subsubsection{Hypothesis Test}

The baseline condition (i.e., null hypothesis) and alternative condition are:

- Baseline condition - Closure objectives have not been met

- Alternative condition - Closure objectives have been met

Sufficient evidence to reject the null hypothesis is:

- The identification of the lateral and vertical extent of COC contamination in media, if present.

- Sufficient information to properly dispose of IDW and remediation waste.

\subsubsection{Statistical Model}

A judgmental sampling design will be implemented to select sample locations and evaluate DQO decisions for CAU 114. The judgmental sampling design as implemented at CAU 114 assumes that the data are not normally distributed.

\subsubsection{Design Description/Option}

Because individual sample results, rather than an average concentration, will be used to compare to FALs, statistical methods to generate site characteristics will not be used. Adequate representativeness of the entire target population may not be a requirement to developing a sampling design. If good prior information is available on the target site of interest, then the sampling may be designed to collect samples only from areas known to have the highest concentration levels on the target site. If the observed concentrations from these samples are below the action level, then a 
decision can be made that the site contains safe levels of the contaminant without the samples being truly representative of the entire area (EPA, 2006).

All sample locations will be selected to satisfy the DQI of representativeness in that samples collected from selected locations will best represent the populations of interest as defined in Section B.5.1. To meet this criterion for judgmentally sampled sites, a biased sampling strategy will be used for Decision I samples to target areas with the highest potential for contamination, if it is present anywhere in the CAS. Sample locations will be determined based on process knowledge, previously acquired data, or the field-screening and biasing factors listed in Section B.4.2.1. If biasing factors are present in soils below locations where Decision I samples were removed, additional Decision I soil samples will be collected at depth intervals selected by the Site Supervisor based on biasing factors to a depth where the biasing factors are no longer present. The Site Supervisor has the discretion to modify the judgmental sample locations, but only if the modified locations meet the decision needs and criteria stipulated in this DQO.

\subsubsection{Conceptual Site Model and Drawing}

The CSM describes the most probable scenario for current conditions at each site and defines the assumptions that are the basis for identifying the future land use, contaminant sources, release mechanisms, migration pathways, exposure points, and exposure routes. The CSM is also used to support appropriate sampling strategies and data collection methods. The CSM has been developed for CAU 114 using information from the physical setting, potential contaminant sources, release information, historical background information, knowledge from similar sites, and physical and chemical properties of the potentially affected media and COPCs. Figure 3-2 depicts a tabular representation of the conceptual pathways to receptors from CAU 114 sources. Figure 3-3 depicts a graphical representation of the CSM for potential surface and shallow subsurface releases. If evidence of contamination that is not consistent with the presented CSM is identified during CAI activities, the situation will be reviewed, the CSM will be revised, the DQOs will be reassessed, and a recommendation will be made as to how best to proceed. In such cases, participants in the DQO process will be notified and given the opportunity to comment on and/or concur with the recommendation. A detailed discussion of the CSM is presented in Appendix B. 


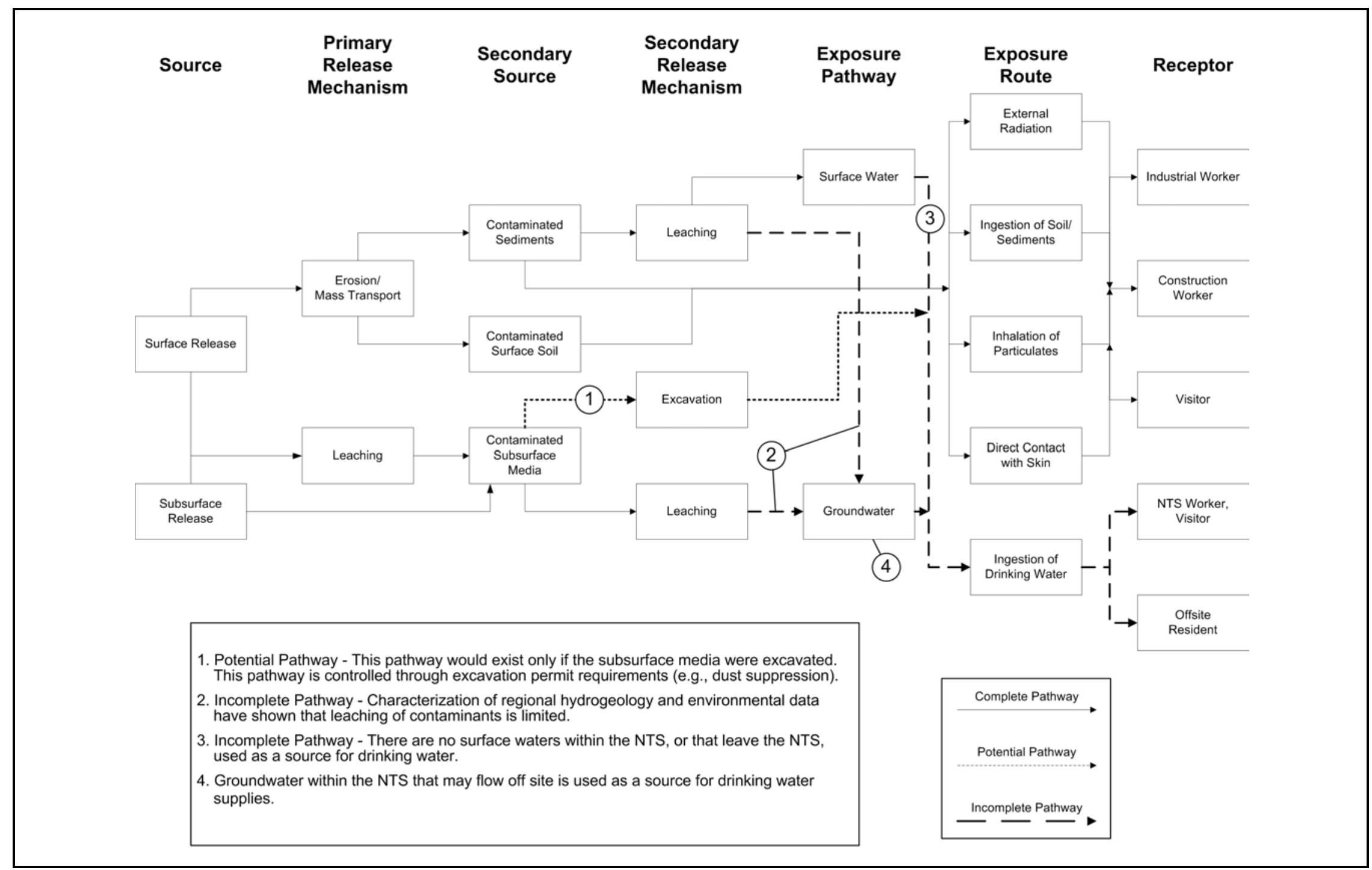

Figure 3-2

Conceptual Site Model Diagram for CAU 114

\section{UNCONTROLLED When Printed}




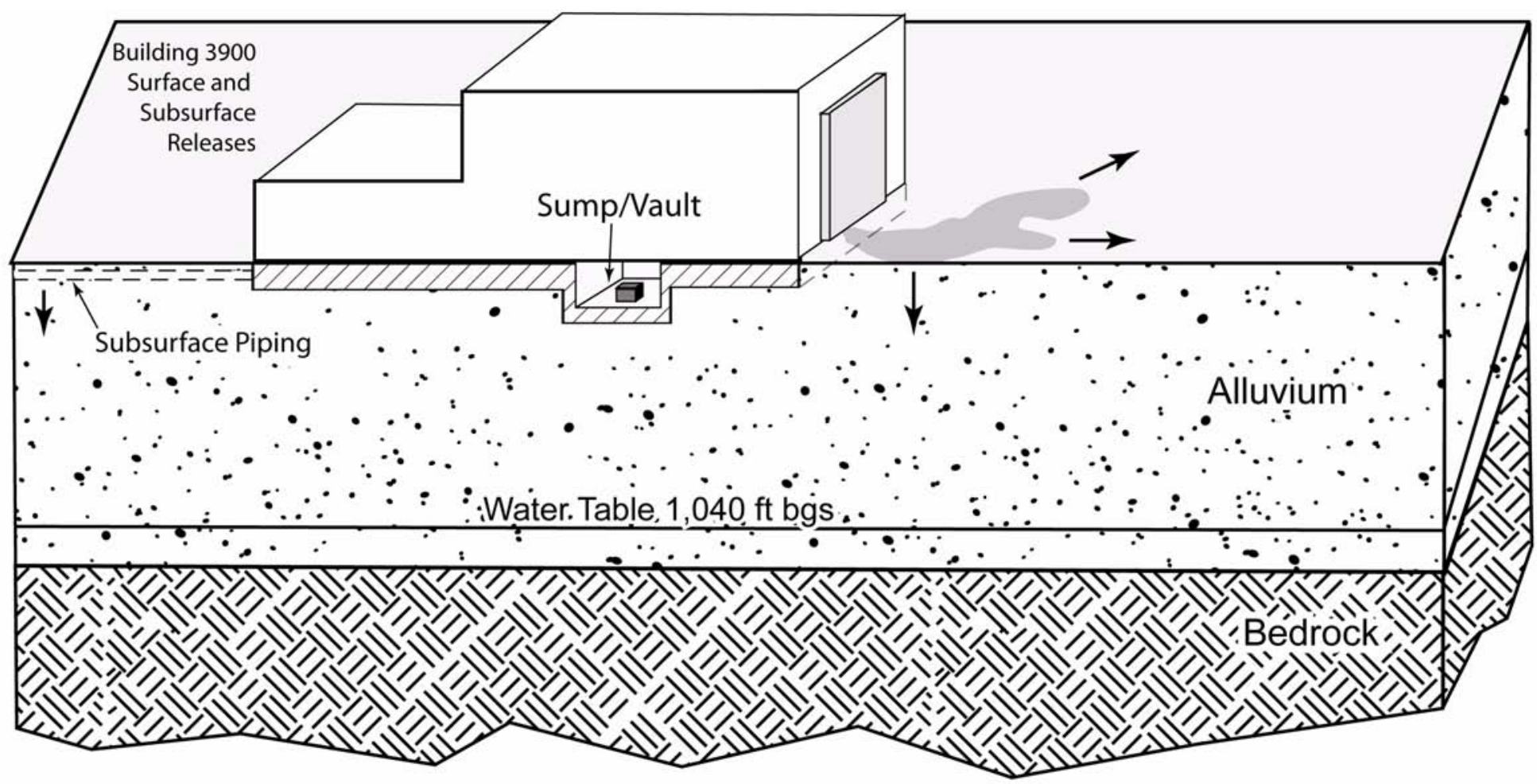

Figure 3-3

Conceptual Site Model for CAU 114 


\subsection{Field Activities and Closure Objectives}

This section of the SAFER Plan provides a description of the field activities and closure objectives for CAU 114. The objectives for the field activities are to determine whether PSMs exist. If clean closure cannot be accomplished during the SAFER, then the extent of the remaining contamination will be determined so that closure alternatives may be implemented. If clean closure cannot be accomplished during the SAFER, then a hold point will have been reached and NDEP will be consulted to determine whether the remaining contamination will be closed under the alternative corrective action of closure in place. All sampling activities will be conducted in compliance with the Industrial Sites QAPP (NNSA/NV, 2002b) and other applicable, approved procedures and instructions.

\subsection{Contaminants of Potential Concern}

The COPCs for CAU 114 are defined as the list of constituents represented by the analytical methods identified in Table 3-1 for Decision I samples taken at each CAS. The constituents reported for each analytical method are listed in Table 3-2.

The list of COPCs is intended to encompass all of the contaminants that could potentially be present at each CAS. These COPCs were identified during the planning process through the review of site history, process knowledge, personal interviews, past investigation efforts, and inferred activities associated with the CAS. Contaminants detected at similar NTS sites were included in the COPC list to reduce the uncertainty about potential contamination at each CAS because complete information regarding activities performed at the CAU 114 site is not available. The following sections discuss each of the COPCs for CAU 114.

\subsubsection{Total Petroleum Hydrocarbons}

Total petroleum hydrocarbons are primarily associated with oils, greases, and fuels required to operate equipment such as that found throughout the E-MAD Facility. 


\subsubsection{Volatile and Semivolatile Organic Compounds}

Volatile organic compounds and SVOCs are found in fuels, oils, greases, products for cleaning mechanical and electrical parts, and freons. As such, VOCs and SVOCs may be present in all primary and support areas of Building 3900, the support structures throughout the facility, and in the surrounding environment where equipment may have been parked or serviced.

\subsubsection{Polychlorinated Biphenyls}

Based on visual surveys and process knowledge, it is anticipated that oils from hydraulic equipment inside and outside of Building 3900 may contain PCBs (e.g., locomotives, railcars, hydraulic hoses, compressors, door actuators). Polychlorinated biphenyl-containing items including light ballasts and capacitors are known to be present throughout Building 3900 as well as in exterior structures (trailers, shacks, and sheds) and debris piles. There is also the potential for PCB-containing transformers to have been used during the operational history of the E-MAD Facility.

\subsubsection{Resource Conservation and Recovery Act Metals and Beryllium}

It is anticipated that RCRA metals may be present in materials throughout Building 3900 as well as in materials associated with the exterior CAS components. Lead-containing items include various types of lead shielding (e.g., leaded-glass windows, lead shot, lead bricks, lead plates), lead-acid batteries, and lead fuses. Mercury-containing items include mercury vapor light bulbs, thermostats, and switches. Based upon process knowledge from similar facilities, there is a potential for pipe systems to contain cadmium foil wrapping. Fuel elements containing a mixture of highly enriched uranium dioxide and beryllium oxide were handled in Building 3900 as part of the NERVA project and, as a result, Building 3900 is listed as a beryllium legacy site. As such, there is a potential to encounter beryllium surface or soil contamination. All surface soil samples will be analyzed for beryllium. It is also expected that excess chemicals will be identified throughout Building 3900 that may contain RCRA metals.

\subsubsection{Pesticides}

Based on process knowledge from similar CASs at the NTS, pesticides may be present in surface or shallow subsurface soils. 


\subsubsection{Radionuclides}

Process knowledge of previous activities undertaken at the E-MAD Facility provides reasonable expectation of the presence of radionuclide contamination. It is expected that radiological contamination of surfaces (e.g., walls, floors, equipment) will be located primarily in the Hot Bay Complex, but all samples, including soil samples, collected at all the CAS components will be analyzed for radionuclides. Potential sources of radiological contamination include, but are not limited to, depleted uranium (DU) counterweights on manipulator arms; radioactive check sources; high-efficiency particulate air (HEPA) ventilation systems; and miscellaneous materials found in the Hot Bay Complex, including any contents in subsurface vaults and pits.

\subsection{Remediation}

The DQOs developed for CAU 114 identified data gaps that require additional data collection before identifying and implementing the preferred closure alternative for each CAS. A decision point approach, based on the DQOs, for making remediation decisions is summarized in Figure 1-4. The presence of contamination, if any, is assumed to be confined to the spatial boundaries of the sites as defined in the DQO process and CSM.

If PSMs that could cause COCs in environmental media are identified within a CAS (or CAS component) based on the initial CAI results, that CAS (or component) will be further assessed before implementing closure activities. If PSMs are not present, the CAS will be recommended for no further action. The objective of the initial investigation strategy is to determine whether PSMs are present. Laboratory analytical results will be used to confirm the presence or absence of PSMs.

If PSMs are present, or it is decided that PSMs may be present based on the presence of biasing factors, that material will be removed. Materials that do not meet PSM criteria as defined in Section 3.1 may remain in place.

The judgmental sampling strategy is presented in Appendix B. Predetermined biased sample locations may be justified by the Site Supervisor, based on the criteria for satisfying DQO data needs listed in Appendix B. Additional samples may be collected for waste management characterization and disposal purposes. 
The closure strategy for CAU 114 under this SAFER process consists of the following stages, discussed in further detail below:

- Sampling and identifying PSMs

- Removing PSM and assumed PSM

\subsubsection{Sampling for COCs and PSMs}

Table 4-1 summarizes the sampling approach to achieve closure objectives for CAU 114. Potential source material samples will be collected from materials that are suspected to contain COPCs and that may cause the future release of a COC to environmental media. For CAU 114, there are materials that have been assumed to meet PSM criteria and will therefore be removed and disposed of, without the need for sampling. Table 4-2 lists the known or anticipated PSMs at CAU 114 and indicates which materials will be sampled and which will be assumed PSM. Detailed information regarding the sampling plan is outlined in Appendix B.

Table 4-1

Sampling Approach for CAU 114

\begin{tabular}{||c|c|c|c|c|c||}
\hline CAS & $\begin{array}{c}\text { Sample } \\
\text { Location }\end{array}$ & $\begin{array}{c}\text { Minimum } \\
\text { Number } \\
\text { of Sample } \\
\text { Locations }\end{array}$ & $\begin{array}{c}\text { Minimum } \\
\text { Number } \\
\text { of Samples } \\
\text { per Location }\end{array}$ & $\begin{array}{c}\text { Sample } \\
\text { Collection/Submittal } \\
\text { Requirements }\end{array}$ & $\begin{array}{c}\text { Sampling } \\
\text { Methods }\end{array}$ \\
\hline \hline $\begin{array}{c}\text { 25-41-03 } \\
\text { EMAD Facility }\end{array}$ & $\begin{array}{c}\text { Wastes and } \\
\text { PSM, concrete }\end{array}$ & TBD & 1 & $\begin{array}{l}\text { Collect samples based on } \\
\text { identified biasing factors. } \\
\text { Submit all samples collected } \\
\text { based on biasing factors. } \\
\text { Concrete (e.g., walls, floors, } \\
\text { foundations) may be sampled } \\
\text { (based on radiological } \\
\text { surveys) using core } \\
\text { drilling techniques. }\end{array}$ & $\begin{array}{c}\text { Hand } \\
\text { sampling, } \\
\text { backhoe } \\
\text { excavation, } \\
\text { core drilling }\end{array}$ \\
\hline
\end{tabular}

${ }^{a}$ For worker protection, field screening will not be conducted if a strong odor and/or visual evidence suggests contamination is present.

${ }^{\mathrm{b}}$ Additional samples may be collected and submitted to the lab at the discretion of the Site Supervisor.

$\mathrm{TBD}=$ To be determined 
Table 4-2

Known or Anticipated Potential Source Materials

\begin{tabular}{|c|c|c|c|}
\hline Potential Source $^{a}$ & Material & Contaminants $^{b}$ & Sample/Assumed \\
\hline $\begin{array}{l}\text { PCB-containing } \\
\text { ballast capacitors }\end{array}$ & Ballast material & PCBs & Assumed \\
\hline Excess chemicals & Chemicals & $\begin{array}{l}\text { VOCs, SVOCs, } \\
\text { RCRA Metals }\end{array}$ & Sample \\
\hline HEPA filters & Filter paper & Radiological & Sample \\
\hline Fluorescent light bulbs & Gases, RCRA Metals & RCRA Metals & Assumed \\
\hline Freon & Gases & RCRA Metals & Assumed \\
\hline Mercury vapor lights & Gases, RCRA Metals & RCRA Metals & Assumed \\
\hline Sodium vapor lights & Gases & RCRA Metals & Assumed \\
\hline Radiological check sources & Metals & Radiological & Sample \\
\hline DU counterweights & Metals & Radiological & Assumed \\
\hline Lead-containing fuses & Metals & RCRA Metals & Assumed \\
\hline Lead-acid batteries & Metals & RCRA Metals & Assumed \\
\hline Mercury-containing items & Metals & RCRA Metals & Assumed \\
\hline Circuit boards & Metals & RCRA Metals, Radiological & Assumed \\
\hline Lead-glass windows & Metals & RCRA Metals, Radiological & Assumed \\
\hline Lead solids/shielding & Metals & RCRA Metals, Radiological & Assumed \\
\hline Mineral oil & Oils & Radiological & Sample \\
\hline Diesel fuel & Oils & $\begin{array}{l}\text { VOCs, SVOCs, } \\
\text { Radiological }\end{array}$ & Sample \\
\hline $\begin{array}{l}\text { Compressor, gear, and } \\
\text { hydraulic oils }\end{array}$ & Oils & $\begin{array}{l}\text { VOCs, SVOCs, PCBs, } \\
\text { RCRA Metals, Radiological }\end{array}$ & Sample \\
\hline Motor oil & Oils & $\begin{array}{l}\text { VOCs, SVOCs, PCBs, } \\
\text { RCRA Metals }\end{array}$ & Sample \\
\hline
\end{tabular}

${ }^{\mathrm{a}}$ Other wastes may be identified during the CAI.

${ }^{\mathrm{b}}$ The listed contaminants are the best available based on site history and process knowledge. Actual analytical suites will be determined in the field on a case-by-case basis based on process knowledge, field conditions, etc.

Note: Sample vs. assumed - Some PSMs will be assumed that a contaminant is present and be treated as such with no samples being collected or analyzed. Other PSMs will be sampled to determine whether and what contaminants are present. 


\subsection{Verification}

The information necessary to satisfy the closure criteria will be generated for CAU 114 by collecting and analyzing samples generated during the field investigation. If a PSM is present and removed during the SAFER, verification sampling may be required. The final locations and numbers of samples to be collected will be determined in the field based on the presence of any biasing factors as listed in Section B.4.2.1, site conditions, and the professional judgment of the Site Supervisor. All sample locations must meet the DQO decision needs and criteria stipulated in Appendix B. The number and location of verification samples will be justified in the CR.

\subsection{Closure}

The following activities, at a minimum, have been identified for closure of CAS 25-41-03. The decision logic behind the activities is provided in Figure 1-4:

- If no PSMs are identified during SAFER activities, a CAA of no further action will be selected.

- If PSMs are identified, then a corrective action is required.

- If PSMs are identified and clean closure cannot be accomplished during the SAFER, then the remaining contamination will be closed under the alternative corrective action of closure in place. The appropriate URs will then be implemented and documented in the CR.

- If PSMs are identified and clean closure can be accomplished during the SAFER, clean closure will be the selected corrective action. The material to be remediated will be removed and disposed of as waste.

Following completion of CAI and waste management activities, the following actions will be implemented:

- Removing all equipment, wastes, debris, and materials associated with the CAI.

- Removing all CAI signage and fencing (unless part of a corrective action).

- Grading site to pre-investigation condition (unless changed condition is necessary under a corrective action).

- Inspecting the site and certifying that restoration activities have been completed. 
Future activities may include demolition of Building 3900 and support buildings/structures. When demolition takes place, it will be completed outside of the FFACO process.

\subsection{Duration}

Table 4-3 provides a tentative duration of activities (in calendar days) for SAFER activities:

Table 4-3

SAFER Field Activities

\begin{tabular}{|c|c|}
\hline Duration (days) & Activity \\
\hline \hline 90 & Site Preparation/Mobilization \\
\hline 240 & Sampling for COCs and Identification of PSMs \\
\hline 120 & Identification and Removal of Assumed PSMs (those that do not require sampling) \\
\hline 90 & Sample Analysis/Validation \\
\hline 120 & Waste Characterization \\
\hline
\end{tabular}




\subsection{Reports and Records Availability}

Reports generated during ongoing field activities will be provided to NDEP upon request. Historic information and documents referenced in this plan are retained in the NNSA/NSO project files in Las Vegas, Nevada, and can be obtained through written request to the NNSA/NSO Project Manager. This document is available in the DOE public reading rooms located in Las Vegas and Carson City, Nevada, or by contacting the appropriate DOE project manager. The NDEP maintains the official Administrative Record for all activities conducted under the auspices of the FFACO. 


\subsection{Investigation/Remediation Waste Management}

Management of IDW will be based on regulatory requirements, field observations, process knowledge, and laboratory results from CAU 114 investigation samples.

Disposable sampling equipment, personal protective equipment (PPE), and rinsate are considered potentially contaminated waste only by virtue of contact with potentially contaminated media (e.g., soil) or potentially contaminated debris (e.g., construction materials). Therefore, sampling and analysis of IDW, separate from analyses of site investigation samples, may not be necessary for all IDW. However, if associated investigation samples are found to contain contaminants above regulatory levels, conservative estimates of total waste contaminant concentrations may be made based on the mass of the waste, the amount of contaminated media contained in the waste, and the maximum concentration of contamination found in the media. Direct samples of IDW may also be taken to support waste characterization.

Industrial, hazardous, radioactive, and/or mixed waste, if generated, will be managed and disposed of in accordance with applicable DOE orders, U.S. Department of Transportation (DOT) regulations, state and federal waste regulations, and agreements and permits between DOE and NDEP. Materials left in place are not considered to be generated wastes and are not subject to RCRA or the requirements of the sections below.

\subsection{Waste Minimization}

Investigation activities are planned to minimize IDW generation. This will be accomplished by incorporating the use of process knowledge, visual examination, and/or radiological survey and swipe results. When possible, disturbed media (such as soil removed during trenching) or debris will be returned to its original location. Contained media (e.g., soil managed as waste) as well as other IDW will be segregated to the greatest extent possible to minimize generation of hazardous, radioactive, or mixed waste. Hazardous material used at the sites will be controlled in order to limit unnecessary generation of hazardous or mixed waste. Administrative controls, including decontamination procedures and waste characterization strategies, will minimize waste generated during investigations. 


\subsection{Potential Waste Types}

Waste generated during the CAAs may include the following potential waste types:

- Industrial waste

- Low-level radioactive waste

- Hazardous waste

- Hydrocarbon waste

- Mixed LLW

- Toxic Substances Control Act (TSCA) waste: PCBs, asbestos

Process knowledge may be used for waste designation/disposal for commonly disposed items, such as fluorescent and incandescent light bulbs, scrap lead, light ballasts, and capacitors. No sampling for hazardous waste constituents (e.g., RCRA constituents) is required, although radiological surveys may be required to determine whether the waste meets the regulatory requirements of LLW.

The onsite management and ultimate disposition of wastes will be determined based on the waste type (e.g., industrial, low-level, hazardous, hydrocarbon, mixed), or the combination of waste types. A determination of the waste type will be guided by several factors, including, but not limited to, the analytical results of samples either directly or indirectly associated with the waste, historical site knowledge, knowledge of the waste generation process, field observations, field-monitoring/ screening results, and/or radiological survey/swipe results. Onsite IDW management requirements by waste type are detailed in the following sections.

\subsubsection{Industrial Waste}

Industrial IDW generated at CAU 114 will be collected, managed, and disposed of in accordance with the industrial waste management regulations and the permits for operation of the U10c Industrial Waste Landfill.

\subsubsection{Low-Level Radioactive Waste}

Low-level waste generated at CAU 114 will be packaged and managed in accordance with all applicable federal, state, and NTS requirements. Low-level waste may be generated as a result of operations in areas where radioactive materials are or were formerly managed. Low-level waste 
forms expected at CAU 114 include PPE, debris, tools, and equipment primarily from the Hot Bay Complex.

Nonhazardous solid waste that exceeds the permissible radiological surface and mass concentration for the U10c Industrial Waste Landfill will be managed as LLW. Low-level radioactive waste, if generated, will be managed in accordance with the contractor-specific waste certification program plan, DOE orders, and the requirements of the current version of the Nevada Test Site Waste Acceptance Criteria (NTSWAC) (NNSA/NSO, 2009b). Potential radioactive waste containers containing soil, PPE, disposable sampling equipment, and/or rinsate may be staged at a designated radioactive material area (RMA) or radiologically controlled area (RCA) when full or at the end of an investigation phase. The waste drums will remain at the RMA pending certification and disposal under the current NTSWAC requirements (NNSA/NSO, 2009b).

\subsubsection{Hazardous Waste}

This CAU will have waste accumulation areas established according to the needs of the project. Satellite accumulation areas and hazardous waste accumulation areas (HWAAs) will be managed consistent with the current requirements of federal and state regulations (CFR, 2009a; NAC, 2008b). The HWAAs will be controlled for access, and will be equipped with spill kits and appropriate spill containment. Suspected hazardous wastes will be placed in DOT-compliant containers. All containerized hazardous waste will be handled, inspected, and managed in accordance with the current requirements of federal and state regulations. These provisions include managing the waste in containers compatible with the waste type, and segregating incompatible waste types so that in the event of a spill, leak, or release, incompatible wastes shall not contact one another. The HWAAs will be covered under a site-specific emergency response and contingency action plan until such time that the waste is determined to be nonhazardous or all containers of hazardous waste have been removed from the storage area. Hazardous waste will be characterized in accordance with the requirements of Title 40 Code of Federal Regulations (CFR) 261 (CFR, 2009a). Resource Conservation and Recovery Act -“listed” waste has not been identified at CAU 114. Any waste determined to be hazardous will be managed and transported in accordance with RCRA and DOT requirements to a RCRA-permitted treatment, storage, and disposal facility. Items with the potential of being 
RCRA-regulated hazardous waste were identified during previous site visits. These items include mercury-vapor lamps, mercury switches, lead bricks, and similar items.

\subsubsection{Hydrocarbon Waste}

Hydrocarbon contaminated soil waste containing more than $100 \mathrm{mg} / \mathrm{kg}$ of TPH will be managed on site in a drum or other appropriate container until fully characterized. Hydrocarbon waste may be disposed of at a designated hydrocarbon landfill, an appropriate hydrocarbon waste management facility (e.g., recycling facility), or other method in accordance with Nevada regulations and disposal permits issued by NDEP to NNSA/NSO.

\subsubsection{Mixed Low-Level Waste}

Mixed waste, if generated, shall be managed and dispositioned in accordance with current RCRA requirements, agreements between NNSA/NSO and the State of Nevada, and DOE requirements for radioactive waste. Waste characterized as mixed will not be stored for a period of time that exceeds the requirements of RCRA unless subject to agreements between NNSA/NSO and the State of Nevada. The mixed waste shall be transported via an approved hazardous waste/radioactive waste transporter to the NTS transuranic waste storage pad for storage pending treatment or disposal. Mixed waste meeting Land Disposal Restrictions may be disposed of at the NTS Area 5 Radioactive Waste Management Site if the waste meets the current requirements of the NTSWAC (NNSA/NSO, 2009b), the NTS NDEP permit for a Hazardous Waste Management Facility (NDEP, 2005), and the RCRA Part B Permit Application for Waste Management Activities at the NTS (DOE/NV, 1999b). Mixed waste constituent concentrations exceeding Land Disposal Restrictions will require development of a treatment and disposal plan under the current requirements of the Mutual Consent Agreement between DOE and the State of Nevada (NDEP, 1995).

\subsubsection{Toxic Substances Control Act Waste}

Waste governed by TSCA (USC, 2009) includes PCB waste (solid or liquid) and asbestos. 


\subsubsection{Polychlorinated Biphenyls}

The management of PCBs is governed by TSCA and its implementing current regulations at 40 CFR 761 (CFR, 2009b). Polychlorinated biphenyl contamination may be found as a sole contaminant or in combination with any of the types of waste discussed in this document. For example, PCBs may be a co-contaminant in soil that contains a RCRA "characteristic" waste (PCB/hazardous waste), or in soil that contains radioactive wastes (PCB/radioactive waste), or even in mixed waste (PCB/radioactive/hazardous waste). The IDW will initially be evaluated using analytical results for media samples from the CAI. If any type of PCB waste is generated, it will be managed in accordance with 40 CFR 761 (CFR, 2009b) as well as current State of Nevada requirements (NAC, 2008a), guidance, and agreements with NNSA/NSO.

\subsubsection{Asbestos-Containing Material}

Asbestos-containing material (ACM) has been identified in Building 3900. Piping and tank insulation is suspected of containing asbestos. Floor and ceiling tiles used throughout Building 3900 and in exterior sheds and trailers may also contain asbestos. Asbestos-containing material will be removed by trained asbestos workers. Disposal options for ACM may vary depending on other contaminants present in the waste. All asbestos will be disposed of in accordance with NTSWAC (NNSA/NSO, 2009b). Friable asbestos will be disposed of at the Mercury Sanitary Landfill. Non-friable asbestos will be disposed of at the U10c Industrial Waste Landfill. Radiologically contaminated asbestos waste will be disposed of at the Low-Level Waste Facility. 


\subsection{Quality Assurance/Quality Control}

The overall objective of the characterization activities described in this SAFER Plan is to collect accurate and defensible data to support the selection and implementation of a closure alternative for CAU 114. Sections 7.1 and 7.2 discuss the collection of required quality control (QC) samples in the field and quality assurance (QA) requirements for laboratory/analytical data to achieve closure. Unless otherwise stated in this SAFER Plan or required by the results of the DQO process (see Appendix B), this CAI will adhere to the Industrial Sites QAPP (NNSA/NV, 2002b).

\subsection{Sample Collection Activities}

Field QC samples will be collected in accordance with established procedures. Field QC samples are collected and analyzed to aid in determining the validity of sample results. The number of required QC samples depends on the types and number of samples collected. The minimum frequencies of collecting and analyzing QC samples for this CAI, as determined in the DQO process, include:

- Trip blanks (1 per sample cooler containing VOC samples)

- Equipment rinsate blanks (1 per sampling event for each type of decontamination method)

- Source blanks (1 per uncharacterized lot of source water)

- Field duplicates (1 per 20 samples)

- Field blanks (minimum of 1 per CAS, additional if field conditions change)

- Laboratory QC samples (1 per 20 samples)

Additional QC samples may be submitted based on site conditions at the discretion of the Task Manager or Site Supervisor. Field QC samples shall be analyzed using the same analytical procedures implemented for associated samples. Additional details regarding field QC samples are available in the Industrial Sites QAPP (NNSA/NV, 2002b).

\subsection{Applicable Laboratory/Analytical Data Quality Indicators}

The DQIs are qualitative and quantitative descriptors used in interpreting the degree of acceptability or utility of data. Data quality indicators are used to evaluate the entire measurement system and laboratory measurement processes (i.e., analytical method performance) as well as individual 
analytical results (i.e., parameter performance). The quality and usability of data used to make DQO decisions will be assessed based on the following DQIs:

- Precision

- Accuracy/bias

- Representativeness

- Completeness

- Comparability

- Sensitivity

Table 7-1 provides the established analytical method/measurement system performance criteria for each of the DQIs and the potential impacts on the decision if the criteria are not met. The following subsections discuss each of the DQIs that will be used to assess the quality of laboratory data. The criteria for precision and accuracy in Tables 3-3 and 3-4 may vary from information in the Industrial Sites QAPP as a result of the laboratory used or updated/new methods (NNSA/NV, 2002b).

\subsubsection{Precision}

Precision is a measure of the repeatability of the analysis process from sample collection through analysis results. It is used to assess the variability between two equal samples.

Determinations of precision will be made for field duplicate samples and laboratory duplicate samples. Field duplicate samples will be collected simultaneously with samples from the same source under similar conditions in separate containers. The duplicate sample will be treated independently of the original sample in order to assess field impacts and laboratory performance on precision through a comparison of results. Laboratory precision is evaluated as part of the required laboratory internal QC program to assess performance of analytical procedures. The laboratory sample duplicates are an aliquot, or subset, of a field sample generated in the laboratory. They are not a separate sample but a split, or portion, of an existing sample.

Precision is a quantitative measure used to assess overall analytical method and field-sampling performance as well as the need to "flag" (qualify) individual parameter results when corresponding QC sample results are not within established control limits. 
Table 7-1

Laboratory and Analytical Performance Criteria for CAU 114 DQIs

\begin{tabular}{|c|c|c|}
\hline DQI & Performance Metric & $\begin{array}{l}\text { Potential Impact on Decision } \\
\text { If Performance Metric Not Met }\end{array}$ \\
\hline Precision & $\begin{array}{l}\text { At least } 80 \% \text { of the sample results for each } \\
\text { measured contaminant are not qualified for } \\
\text { precision based on the criteria for each analytical } \\
\text { method-specific and laboratory-specific criteria } \\
\text { presented in Section 7.2.1. }\end{array}$ & $\begin{array}{l}\text { The affected analytical results from each } \\
\text { affected CAS component will be assessed } \\
\text { to determine whether there is sufficient } \\
\text { confidence in analytical results to use the } \\
\text { data in making DQO decisions. }\end{array}$ \\
\hline Accuracy & $\begin{array}{l}\text { At least } 80 \% \text { of the sample results for each } \\
\text { measured contaminant are not qualified for } \\
\text { accuracy based on the method-specific and } \\
\text { laboratory-specific criteria presented in } \\
\text { Section 7.2.2. }\end{array}$ & $\begin{array}{l}\text { The affected analytical results from each } \\
\text { affected CAS component will be assessed } \\
\text { to determine whether there is sufficient } \\
\text { confidence in analytical results to use the } \\
\text { data in making DQO decisions. }\end{array}$ \\
\hline Representativeness & $\begin{array}{l}\text { Samples contain contaminants at concentrations } \\
\text { present in the environmental media from which they } \\
\text { were collected. }\end{array}$ & $\begin{array}{l}\text { Analytical results will not represent true } \\
\text { site conditions. Inability to make } \\
\text { appropriate DQO decisions. }\end{array}$ \\
\hline $\begin{array}{l}\text { Decision I } \\
\text { Completeness }\end{array}$ & $\begin{array}{l}80 \% \text { of the CAS-specific COPCs have valid results. } \\
100 \% \text { of CAS-specific targeted contaminants have } \\
\text { valid results. }\end{array}$ & $\begin{array}{l}\text { Cannot support/defend decision on } \\
\text { whether COCs are present. }\end{array}$ \\
\hline $\begin{array}{c}\text { Decision II } \\
\text { Completeness }\end{array}$ & $\begin{array}{l}100 \% \text { of COCs used to define extent have valid } \\
\text { results. }\end{array}$ & $\begin{array}{l}\text { Extent of contamination cannot be } \\
\text { accurately determined. }\end{array}$ \\
\hline Comparability & $\begin{array}{l}\text { Sampling, handling, preparation, analysis, } \\
\text { reporting, and data validation are performed using } \\
\text { standard methods and procedures. }\end{array}$ & $\begin{array}{l}\text { Inability to combine data with data } \\
\text { obtained from other sources and/or } \\
\text { inability to compare data to regulatory } \\
\text { action levels. }\end{array}$ \\
\hline Sensitivity & $\begin{array}{l}\text { Minimum detectable concentrations are less than } \\
\text { or equal to respective PALs. }\end{array}$ & $\begin{array}{l}\text { Cannot determine whether COCs are } \\
\text { present or migrating at levels of concern. }\end{array}$ \\
\hline
\end{tabular}

The criteria used for the assessment of inorganic chemical precision when both results are greater than or equal to $5 x$ reporting limit (RL) are 20 and 35 percent for aqueous and soil samples, respectively. When either result is less than $5 x \mathrm{RL}$, a control limit of $\pm 1 \mathrm{x} R \mathrm{R}$ and $\pm 2 \mathrm{x}$ RL for aqueous and soil samples, respectively, is applied to the absolute difference.

The criteria used for the assessment of organic chemical precision are based on professional judgment using laboratory-derived control limits. The criteria used for the assessment of radiological precision when both results are greater than or equal to 5x MDC are 20 and 35 percent for aqueous and soil samples, respectively. When either result is less than $5 x$ MDC, the ND should be between -2 and +2 for aqueous and soil samples. The parameters to be used for assessment of precision for duplicates are listed in Table 3-4. 
Any values outside the specified criteria do not necessarily result in the qualification of analytical data. It is only one factor in making an overall judgment about the quality of the reported analytical results. The performance metric for assessing the DQI of precision on DQO decisions (Table 7-1) is that at least 80 percent of sample results for each measured contaminant are not qualified due to duplicates exceeding the criteria. If this performance is not met, an assessment will be conducted in the CR of the impacts on DQO decisions specific to affected contaminants and CAS components.

\subsubsection{Accuracy/Bias}

Accuracy is a measure of the closeness of an individual measurement to the true value. It is used to assess the performance of laboratory measurement processes. Accuracy is determined by analyzing a reference material of known parameter concentration or by reanalyzing a sample to which a material of known concentration or amount of parameter has been added (spiked). Accuracy will be evaluated based on results from three types of spiked samples: MS, LCS, and surrogates (organics). The LCS sample is analyzed with the field samples using the same sample preparation, reagents, and analytical methods employed for the samples. One LCS will be prepared with each batch of samples for analysis by a specific measurement.

The criteria used for the assessment of inorganic chemical accuracy are 75 to 125 percent for MS recoveries and 80 to 120 percent for LCS recoveries. For organic chemical accuracy, MS and LCS laboratory-specific percent recovery criteria developed and generated in-house by the laboratory in accordance with approved laboratory procedures are applied. The criteria used for the assessment of radiochemical accuracy are 80 to 120 percent for LCS and MS recoveries.

Any values outside the specified criteria do not necessarily result in the qualification of analytical data. It is only one factor in making an overall judgment about the quality of the reported analytical results. Factors beyond laboratory control, such as sample matrix effects, can cause the measured values to be outside the established criteria. Therefore, the entire sampling and analytical process may be evaluated when determining the usability of the affected data.

The performance metric for assessing the DQI of accuracy on DQO decisions (Table 7-1) is that at least 80 percent of the sample results for each measured contaminant are not qualified for accuracy. If 
this performance is not met, an assessment will be conducted in the CR of the impacts on DQO decisions specific to affected contaminants and CAS components.

\subsubsection{Representativeness}

Representativeness is the degree to which sample characteristics accurately and precisely represent characteristics of a population or an environmental condition (EPA, 2002). Representativeness is ensured by carefully developing the CAI sampling strategy during the DQO process such that false negative and false positive decision errors are minimized. Meeting the criteria listed below will ensure that sample results will adequately represent actual site characteristics:

- For Decision I judgmental sampling, having a high degree of confidence that the sample locations selected will identify COCs if present anywhere within the CAS.

- Having a high degree of confidence that analyses conducted will be sufficient to detect any COCs present in the samples.

- For Decision II, having a high degree of confidence that the sample locations selected will identify the extent of COCs.

These are qualitative measures that will be used to assess measurement system performance for representativeness. The assessment of this qualitative criterion will be presented in the CR.

\subsubsection{Completeness}

Completeness is defined as generating sufficient data of the appropriate quality to satisfy the data needs identified in the DQOs. For judgmental sampling, completeness will be evaluated using both a quantitative measure and a qualitative assessment. The quantitative measurement to be used to evaluate completeness is presented in Table 7-1 and is based on the percentage of measurements made that are judged to be valid. For the judgmental sampling approach, the completeness goal for targeted contaminants and the remaining COPCs is 100 and 80 percent, respectively. If this goal is not achieved, the dataset will be assessed for potential impacts on making DQO decisions.

The qualitative assessment of completeness is an evaluation of the sufficiency of information available to make DQO decisions. This assessment will be based on meeting the data needs identified 
in the DQOs and will be presented in the CR. Additional samples will be collected if it is determined that the samples collected do not meet completeness criteria.

\subsubsection{Comparability}

Comparability is a qualitative parameter expressing the confidence with which one dataset can be compared to another (EPA, 2002). The criteria for the evaluation of comparability will be that all sampling, handling, preparation, analysis, reporting, and data validation were performed using approved standard methods and procedures. This will ensure that data from this project can be compared to regulatory action levels that were developed based on data generated using the same or comparable methods and procedures. An evaluation of comparability will be presented in the CR.

\subsubsection{Sensitivity}

Sensitivity is the capability of a method or instrument to discriminate between measurement responses representing different levels of the variable of interest (EPA, 2002). The evaluation criterion for this parameter will be that measurement sensitivity (detection limits) will be less than or equal to the corresponding PALs. If this criterion is not achieved, the affected data will be assessed for usability and potential impacts on meeting site characterization objectives. This assessment will be presented in the CR. 


\subsection{References}

AEC/NASA, see Atomic Energy Commission, National Aeronautics and Space Administration.

ASTM, see American Society for Testing and Materials.

American Society for Testing and Materials. 1995 (reapproved 2002). Standard Guide for Risk-Based Corrective Action Applied at Petroleum Release Sites, ASTM E1739 - 95(2002). Philadelphia, PA.

Atomic Energy Commission, National Aeronautics and Space Administration. 1963. Engineering drawing SNP-C-3 titled “N.R.D.S. E-MAD Facility, Phase II Piping, Post Mortem Cells Stack Washdown.”

BN, see Bechtel Nevada.

Bechtel Nevada. 2003a. Engineering drawing titled “Building 25-3900 Basement.” Las Vegas, NV.

Bechtel Nevada. 2003b. Engineering drawing titled “Building 25-3900 First Floor.” Las Vegas, NV.

Bechtel Nevada. 2003c. Engineering drawing titled “Building 25-3900 Fourth Floor.” Las Vegas, NV.

Bechtel Nevada. 2003d. Engineering drawing titled "Building 25-3900 Second Floor.” Las Vegas, NV.

Bechtel Nevada. 2003e. Engineering drawing titled “Building 25-3900 Third Floor.” Las Vegas, NV.

CFR, see Code of Federal Regulations.

Code of Federal Regulations. 2009a. Title 40 CFR, Parts 260-282, “Hazardous Waste Management System: General.” Washington, DC: U.S. Government Printing Office.

Code of Federal Regulations. 2009b. Title 40 CFR, Part 761, "Polychlorinated Biphenyls (PCBs) Manufacturing, Processing, Distribution in Commerce, and Use Prohibitions.” Washington, DC: U.S. Government Printing Office.

DOE, see U.S. Department of Energy.

DOE/NV, see U.S. Department of Energy, Nevada Operations Office.

DRI, see Desert Research Institute. 
Desert Research Institute. 1996. A Historical Evaluation of the Engine Maintenance Assembly and Disassembly Facility, Area 25, Nevada Test Site, Nye County, Nevada, SR082696-1. Prepared by C.M. Beck, H. Drollinger, R. Jones, D. Winslow, and N.G. Goldenberg. Las Vegas, NV.

EPA, see U.S. Environmental Protection Agency.

FFACO, see Federal Facility Agreement and Consent Order.

Federal Facility Agreement and Consent Order. 1996 (as amended March 2010). Agreed to by the State of Nevada; U.S. Department of Energy, Environmental Management; U.S. Department of Defense; and U.S. Department of Energy, Legacy Management.

Geary, K., Peer Consultants. 2006. Telephone interview with T. Thiele (NSTec), J. Myers (SNJV), and S. Engelke (SAIC) regarding CAU 114, CAS 25-41-03, 12 October.

Moore, J., Science Applications International Corporation. 1999. Memorandum to M. Todd (SAIC) titled "Background Concentrations for NTS and TTR Soil Samples," 3 February. Las Vegas, NV: IT Corporation.

Murphy, T., Bureau of Federal Facilities. 2004. Letter to R. Bangerter (NNSA/NSO) titled "Review of Industrial Sites Project Document Guidance for Calculating Industrial Sites Project Remediation Goals for Radionuclides in Soil Using the Residual Radiation (RESRAD) Computer Code,” 19 November. Las Vegas, NV.

NAC, see Nevada Administrative Code.

NBMG, see Nevada Bureau of Mines and Geology.

NCRP, see National Council on Radiation Protection and Measurements.

NDEP, see Nevada Division of Environmental Protection.

NNES, see Navarro Nevada Environmental Services, LLC.

NNES GIS, see Navarro Nevada Environmental Services Geographic Information Systems.

NNSA/NSO, see U.S. Department of Energy, National Nuclear Security Administration Nevada Site Office.

NNSA/NV, see U.S. Department of Energy, National Nuclear Security Administration Nevada Operations Office.

National Council on Radiation Protection and Measurements. 1999. Recommended Screening Limits for Contaminated Surface Soil and Review of Factors Relevant to Site-Specific Studies, NCRP Report No. 129. Bethesda, MD. 
Navarro Nevada Environmental Services, LLC. 2009. Statement of Work for Analytical Laboratories, Section C. Las Vegas, NV.

Navarro Nevada Environmental Services Geographic Information Systems. 2010. ESRI ArcGIS Software.

Nevada Administrative Code. 2008a. NAC 445A.227, "Contamination of Soil: Order by Director for Corrective Action; Factors To Be Considered in Determining Whether Corrective Action Required.” Carson City, NV. As accessed at http://www.leg.state.nv.us/nac on 4 May 2009.

Nevada Administrative Code. 2008b. NAC 445A.22705, "Contamination of Soil: Evaluation of Site by Owner or Operator; Review of Evaluation by Division.” Carson City, NV. As accessed at http://www.leg.state.nv.us/nac on 4 May 2009.

Nevada Administrative Code. 2008c. NAC 445A.2272, "Contamination of Soil: Establishment of Action Levels.” Carson City, NV. As accessed at http://www.leg.state.nv.us/nac on 4 May 2009.

Nevada Bureau of Mines and Geology. 1998. Mineral and Energy Resource Assessment of the Nellis Air Force Range, Open-File Report 98-1. Reno, NV.

Nevada Division of Environmental Protection. 1995. Mutual Consent Agreement between the State of Nevada and the U.S. Department of Energy for the Storage of Low-Level Land Disposal Restricted Mixed Waste. Carson City, NV.

Nevada Division of Environmental Protection. 2005. Nevada Division of Environmental Protection Permit for a Hazardous Waste Management Facility, Permit Number NEV HW0021. Carson City, NV.

Paar, J.G., and D.R. Porterfield. 1997. Evaluation of Radiochemical Data Usability, ES/ER/MS-5. April. Oak Ridge, TN: U.S. Department of Energy.

RSL, see Remote Sensing Laboratory.

Remote Sensing Laboratory. 1976. Aerial photograph “1099-135,” 11 August. Las Vegas, NV: EG\&G Energy Measurements, Inc.

Remote Sensing Laboratory. 2000. Aerial photograph “10292-254,” 2 February. Las Vegas, NV.

Seals, J. 2004. "The Case of the Transuranic-Loving Squirrels, the Decontamination of the XF-90A.” In Radwaste Solutions, November/December, pp. 41-45.

Spezialetti, J., National Security Technologies, LLC. 2007. Email to J. Petrello (SNJV) titled "EMAD Be Results,” March 6.

USC, see United States Code. 
United States Code. 2009. Title 15 USC 2601 et seq., “Toxic Substances Control Act of 1976,” as amended. Washington, DC: U.S. Government Printing Office.

U.S. Department of Energy. 1993. Radiation Protection of the Public and the Environment, DOE Order 5400.5, Change 2. Washington, DC: U.S. Government Printing Office.

U.S. Department of Energy. 1997. The Procedures Manual of the Environmental Measurements Laboratory, HASL-300, 28th edition, Vol. I. February. New York, NY.

U.S. Department of Energy, National Nuclear Security Administration Nevada Operations Office. 2001. Closure Report for Corrective Action Unit 135: Areas 25 Underground Storage Tanks, Nevada Test Site, Nevada, Rev. 1, DOE/NV--717-Rev. 1. Las Vegas, NV.

U.S. Department of Energy, National Nuclear Security Administration Nevada Operations Office. 2002a. Closure Report for Corrective Action Unit 143: Area 25 Contaminated Waste Dumps, Nevada Test Site, Nevada, Rev. 0, DOE/NV--807. Las Vegas, NV.

U.S. Department of Energy, National Nuclear Security Administration Nevada Operations Office. 2002b. Industrial Sites Quality Assurance Project Plan, Nevada Test Site, Nevada, Rev. 3, DOE/NV--372. Las Vegas, NV.

U.S. Department of Energy, National Nuclear Security Administration Nevada Site Office. 2003a. Closure Report for Corrective Action Unit 262: Areas 25 Septic Systems and Underground Discharge Point, Nevada Test Site, Nevada, Rev. 1, DOE/NV--897-REV 1. Las Vegas, NV.

U.S. Department of Energy, National Nuclear Security Administration Nevada Site Office. 2003b. Closure Report for Corrective Action Unit 398: Area 25 Spill Sites, Nevada Test Site, Nevada, Rev. 1, DOE/NV--873-REV 1. Las Vegas, NV.

U.S. Department of Energy, National Nuclear Security Administration Nevada Site Office. 2005. Closure Report for Corrective Action Unit 165: Area 25 and 26 Dry Well and Washdown Areas, Nevada Test Site, Nevada, Rev. 0, DOE/NV--1092. Las Vegas, NV.

U.S. Department of Energy, National Nuclear Security Administration Nevada Site Office. 2006. Industrial Sites Project Establishment of Final Action Levels, Rev. 0, DOE/NV--1107. Las Vegas, NV.

U.S. Department of Energy, National Nuclear Security Administration Nevada Site Office. 2007a. Closure Report for Corrective Action Unit 168: Area 25 and 26 Contaminated Materials and Waste Dumps, Nevada Test Site, Nevada, Rev. 0, DOE/NV--1178. Las Vegas, NV.

U.S. Department of Energy, National Nuclear Security Administration Nevada Site Office. 2007b. Closure Report for Corrective Action Unit 300: Surface Release Areas, Nevada Test Site, Nevada, Rev. 0, DOE/NV--1222. Las Vegas, NV. 
U.S. Department of Energy, National Nuclear Security Administration Nevada Site Office. 2008a. Addendum to the Closure Report for Corrective Action Unit 262: Area 25 Septic Systems and Underground Discharge Point, Nevada Test Site, Nevada, Rev. 0, DOE/NV--897-REV 1-ADD. Las Vegas, NV.

U.S. Department of Energy, National Nuclear Security Administration Nevada Site Office. 2008b. Addendum to the Closure Report for Corrective Action Unit 398: Area 25 Spill Sites, Nevada Test Site, Nevada, Rev. 0, DOE/NV--873-REV 1-ADD. Las Vegas, NV.

U.S. Department of Energy, National Nuclear Security Administration Nevada Site Office. 2008c. Closure Report for Corrective Action Unit 127: Areas 25 and 26 Storage Tanks, Nevada Test Site, Nevada, Rev. 0, DOE/NV--1248. Las Vegas, NV.

U.S. Department of Energy, National Nuclear Security Administration Nevada Site Office. 2008d. Corrective Action Decision Document/Closure Report for Corrective Action Unit 556: Dry Wells and Surface Release Points, Nevada Test Site, Nevada, Rev. 0, DOE/NV--1285. Las Vegas, NV.

U.S. Department of Energy, National Nuclear Security Administration Nevada Site Office. 2009a. Corrective Action Decision Document/Closure Report for Corrective Action Unit 557: Spills and Tank Sites, Nevada Test Site, Nevada, Rev. 0, DOE/NV--1319. Las Vegas, NV.

U.S. Department of Energy, National Nuclear Security Administration Nevada Site Office. 2009b. Nevada Test Site Waste Acceptance Criteria, DOE/NV-325-Rev. 7-01. Las Vegas, NV.

U.S. Department of Energy, Nevada Operations Office. 1983. Histories of Spent Nuclear Fuel Assemblies While at the E-MAD Facility, December 1978 Through September 1982, DOE/NV/10250-6. Las Vegas, NV.

U.S. Department of Energy, Nevada Operations Office. 1995a. Environmental Restoration Sites Inventory - Non-Hazardous Site Cleanup Verification Summary. Las Vegas, NV.

U.S. Department of Energy, Nevada Operations Office. 1995b. Environmental Restoration Sites Inventory - Site Cleanup Verification Summary. Las Vegas, NV.

U.S. Department of Energy, Nevada Operations Office. 1996a. Corrective Action Unit 381 Gas Cylinder Closure Report, 07-CAU381-002. Las Vegas, NV.

U.S. Department of Energy, Nevada Operations Office. 1996b. Corrective Action Unit 382 Housekeeping Closure Report. Las Vegas, NV.

U.S. Department of Energy, Nevada Operations Office. 1997. Closure Report for Housekeeping Category Corrective Action Unit 386, Nevada Test Site, Rev. 1, DOE/NV/11718--129. Las Vegas, NV. 
U.S. Department of Energy, Nevada Operations Office. 1998a. Closure Report for Housekeeping Category Corrective Action Unit 354: Nevada Test Site, Rev. 0, DOE/NV/11718--169.

Las Vegas, NV.

U.S. Department of Energy, Nevada Operations Office. 1998b. Decontamination and Decommissioning Subproject Characterization Report for the E-MAD Decontamination Project, DOE/NV--485. Las Vegas, NV.

U.S. Department of Energy, Nevada Operations Office. 1999a. Closure Report for Housekeeping Category Corrective Action Unit 297: Nevada Test Site, Nevada, Rev. 0, DOE/NV/11718--289. Las Vegas, NV.

U.S. Department of Energy, Nevada Operations Office. 1999b. RCRA Part B Permit (NEV HW0021) Application for Waste Management Activities at the Nevada Test Site. Las Vegas, NV.

U.S. Department of Energy, Nevada Operations Office. 2000a. Housekeeping Closure Report for Corrective Action Unit 119: Storage Tanks, Nevada Test Site, Nevada, Rev. 0, DOE/NV--626. Las Vegas, NV.

U.S. Department of Energy, Nevada Operations Office. 2000b. Housekeeping Closure Report for Corrective Action Unit 288: Area 25 Engine-Maintenance, Assembly, and Disassembly/Treatability Test Facility Chemical Sites, Nevada Test Site, Nevada, Rev. 0, DOE/NV--590. Las Vegas, NV.

U.S. Environmental Protection Agency. 1980. Prescribed Procedures for Measurement of Radioactivity in Drinking Water, EPA 600/4-80-032. Cincinnati, OH: Environmental Monitoring and Support Laboratory Office of Research and Development.

U.S. Environmental Protection Agency. 2000. Sampling and Analysis Plan Guidance and Template, R9QA/002.1. As accessed at http://www.epa.gov/region09/qa/projplans.html on 4 May 2009.

U.S. Environmental Protection Agency. 2002. Guidance for Quality Assurance Project Plans, EPA QA/G5, EPA/240/R-02/009. Washington, DC: Office of Environmental Information.

U.S. Environmental Protection Agency. 2004. USEPA Contract Laboratory Program National Functional Guidelines for Inorganic Data Review, OSWER 9240.1-45/EPA 540-R-04-004. October. Washington, DC: Office of Superfund Remediation and Technology Innovation.

U.S. Environmental Protection Agency. 2006. Guidance on Systematic Planning Using the Data Quality Objectives Process, EPA QA/G-4, EPA/240/B-06/001. Washington, DC: Office of Environmental Information. 
U.S. Environmental Protection Agency. 2009a. Region 9: Superfund, Regional Screening Levels (Formerly PRGs) for Chemical Contaminants. As accessed at http://www.epa.gov/region09/superfund/prg on 4 May. Prepared by EPA Office of Superfund and Oak Ridge National Laboratory.

U.S. Environmental Protection Agency. 2009b. SW-846 On-Line, Test Methods for Evaluating Solid Waste, Physical/Chemical Methods. As accessed at http://www.epa.gov/epaoswer/hazwaste/test/main.htm on 4 May. 


\section{Appendix A}

\section{Project Organization}




\section{A.1.0 Project Organization}

The NNSA/NSO Federal Sub-Project Director is Kevin Cabble. He can be contacted at (702) 295-5000. The NNSA/NSO Task Manager is Tiffany Lantow. She can be contacted at (702) 295-7645.

The identification of the project Health and Safety Officer and the Quality Assurance Officer can be found in the appropriate plan. However, personnel are subject to change, and it is suggested that the NNSA/NSO Federal Sub-Project Director be contacted for further information. The Task Manager will be identified in the FFACO Monthly Activity Report before the start of field activities. 


\section{Appendix B}

\section{Data Quality Objective Process}


The DQO process described in this appendix is a seven-step strategic systematic planning method used to plan data collection activities and define performance criteria for the CAU 114, Area 25 EMAD Facility, field investigation. The DQOs are designed to ensure that the data collected will provide sufficient and reliable information to determine the appropriate corrective actions, to verify the adequacy of existing information, to provide sufficient data to implement the corrective actions, and to verify that closure was achieved.

The CAU 114 CAI will be based on the DQOs presented in this appendix as developed by representatives of NDEP and NNSA/NSO. The seven steps of the DQO process presented in Sections B.2.0 through B.8.0 were developed in accordance with the Guidance on Systematic Planning Using the Data Quality Objectives Process (EPA, 2006) and the CAS-specific information presented in Section B.2.0.

The DQO process presents a judgmental sampling approach. In general, the procedures used in the DQO process provide:

- A method to establish performance or acceptance criteria, which serve as the basis for designing a plan for collecting data of sufficient quality and quantity to support the goals of a study.

- Criteria that will be used to establish the final data collection design such as:

- The nature of the problem that has initiated the study and a conceptual model of the environmental hazard to be investigated.

- The decisions or estimates that need to be made and the order of priority for resolving them.

- The type of data needed.

- An analytic approach or decision rule that defines the logic for how the data will be used to draw conclusions from the study findings.

- Acceptable quantitative criteria on the quality and quantity of the data to be collected, relative to the ultimate use of the data.

- A data collection design that will generate data meeting the quantitative and qualitative criteria specified. A data collection design specifies the type, number, location, and physical quantity of samples and data, as well as the QA and QC activities that will ensure that sampling design and measurement errors are managed sufficiently to meet the performance or acceptance criteria specified in the DQOs. 


\section{B.2.0 Step 1 - State the Problem}

Step 1 of the DQO process defines the problem that requires study, identifies the planning team, and develops a conceptual model of the environmental hazard to be investigated.

The problem statement for CAU 114 is: "Existing information on the nature and extent of potential contamination is insufficient to evaluate and confirm closure of CAS 25-41-03.”

Corrective Action Unit 114 comprises CAS 25-41-03, EMAD Facility, which consists of potential future releases from wastes suspected to contain a material that may cause the release of a COC to environmental media.

\section{B.2.1 Planning Team Members}

The DQO planning team consists of representatives from NDEP, NNSA/NSO, Stoller-Navarro Joint Venture (SNJV), and National Security Technologies, LLC (NSTec). The DQO meeting was held on April 30, 2009. The primary decision makers are the NDEP and NNSA/NSO representatives.

\section{B.2.2 Conceptual Site Model}

The CSM is used to organize and communicate information about site characteristics. It reflects the best interpretation of available information at any point in time. The CSM is a primary vehicle for communicating assumptions about release mechanisms, potential migration pathways, or specific constraints. It provides a summary of how and where contaminants are expected to move and what impacts such movement may have. It is the basis for assessing how contaminants could reach receptors both in the present and future. The CSM describes the most probable scenario for current conditions at each site and define the assumptions that are the basis for identifying appropriate sampling strategy and data collection methods. Accurate CSMs are important as they serve as the basis for all subsequent inputs and decisions throughout the DQO process.

The CSM was developed for CAU 114 using information from the physical setting, potential contaminant sources, release information, historical background information, knowledge from similar sites, and physical and chemical properties of the potentially affected media and COPCs. 
The CSM consists of:

- Potential contaminant releases associated with Building 3900.

- Release mechanisms (the conditions associated with the release).

- Potential contaminant source characteristics, including contaminants suspected to be present and contaminant-specific properties.

- Site characteristics including physical, topographical, and meteorological information.

- Migration pathways and transport mechanisms that describe the potential for migration and where the contamination may be transported.

- The locations of points of exposure where individuals or populations may come in contact with a COC associated with a CAS.

- Routes of exposure where contaminants may enter the receptor.

If additional elements are identified during the CAI that are outside the scope of the CSM, the situation will be reviewed, and a recommendation will be made as to how to proceed. In such cases, NDEP will be notified and given the opportunity to comment on, and concur with, the recommendation.

The applicability of the CSM is summarized in Table B.2-1 and discussed below. Table B.2-1 provides information on CSM elements that will be used throughout the remaining steps of the DQO process.

\section{B.2.2.1 Contaminant Release}

Any contaminants that could be released from CAU 114, regardless of physical or chemical characteristics, are expected to exist in wastes that are currently contained within Building 3900 but could be released to soil following decomposition of the building. Specific release points are described below.

For CAS 25-41-03, EMAD Facility, the primary locations from which contaminants may be released to the environment are any breached locations in waste lines or drains that leave Building 3900 and are in contact with soil. Contamination could occur if PSMs contained within Building 3900 were released to the environment. Examples include used oils in equipment reservoirs, materials left in 
Table B.2-1

Conceptual Site Model Description for CAS 25-41-03 in CAU 114

\begin{tabular}{|c|c|}
\hline CAS Identifier & $25-41-03$ \\
\hline CAS Description & EMAD Facility \\
\hline Site Status & Building 3900 is inactive and abandoned. \\
\hline Exposure Scenario & Occasional Use \\
\hline $\begin{array}{l}\text { Sources of Potential Soil } \\
\text { Contamination }\end{array}$ & $\begin{array}{l}\text { Hazardous or radioactive materials stored at the facility, located in storage vaults } \\
\text { and pits, equipment reservoirs, or discharged to drains and waste systems }\end{array}$ \\
\hline $\begin{array}{l}\text { Location of Contaminationl } \\
\text { Release Point }\end{array}$ & $\begin{array}{l}\text { Release points from drains or waste lines leaving Building } 3900 \text {, or other } \\
\text { identified pathways to soil }\end{array}$ \\
\hline Amount Released & Unknown \\
\hline Affected Media & Surface and shallow subsurface soil \\
\hline Potential Contaminants & $\begin{array}{l}\text { VOCs, SVOCs, TPH-DRO, RCRA Metals + Beryllium, PCBs, Gamma } \\
\text { Spectrometry, Isotopic U, Isotopic Pu, Sr-90 (+ Pesticides at Building 3900) }\end{array}$ \\
\hline Transport Mechanisms & $\begin{array}{l}\text { Percolation of precipitation through subsurface media serves as the major } \\
\text { driving force for migration of contaminants. Surface water runoff may provide for } \\
\text { the transportation of some contaminants within or outside the footprint of the } \\
\text { CAS (e.g., storm drain system, debris piles). Leaks from fuel tanks and/or oil } \\
\text { reservoirs on equipment located inside Building } 3900 \text { onto the soil. }\end{array}$ \\
\hline Migration Pathways & $\begin{array}{l}\text { Vertical transport is expected to dominate lateral transport due to small surface } \\
\text { gradients (with exception of storm drain system). }\end{array}$ \\
\hline $\begin{array}{l}\text { Lateral and Vertical Extent } \\
\text { of Contamination }\end{array}$ & $\begin{array}{l}\text { Contamination, if present, is expected to be contiguous to the release points. } \\
\text { Concentrations are expected to decrease with distance and depth from the } \\
\text { source. Groundwater contamination is not expected. Lateral and vertical extent } \\
\text { of } \mathrm{COC} \text { contamination is assumed to be within the spatial boundaries. }\end{array}$ \\
\hline Exposure Pathways & $\begin{array}{l}\text { The potential for contamination exposure is limited to industrial and construction } \\
\text { workers, and military personnel conducting training. These human receptors } \\
\text { may be exposed to COPCs through oral ingestion, inhalation, and dermal } \\
\text { contact (absorption) of soil and/or debris due to inadvertent disturbance of these } \\
\text { materials, or irradiation by radioactive materials. }\end{array}$ \\
\hline
\end{tabular}

vaults and pits, lead shielding, mercury-containing thermostats and switches, and radioactive check sources. (See Table B.8-1 for a list of known or anticipated PSMs.)

\section{B.2.2.2 Potential Contaminants}

The COPCs were identified during the planning process through the review of site history, process knowledge, personal interviews, past investigation efforts (where available), and inferred activities associated with CAS 25-41-03. The list of COPCs is intended to encompass all of the contaminants that could potentially be present. The COPCs applicable to Decision I samples from CAU 114 are 
defined as the constituents reported from the analytical methods stipulated in Table B.2-2. (See Section 4.1 for a description of the potential sources of the listed COPCs.)

Table B.2-2

Analytical Program ${ }^{\text {a }}$

\begin{tabular}{|c|c||}
\hline Analyses & $\begin{array}{c}\text { CAS 25-41-03 } \\
\text { EMAD Facility }\end{array}$ \\
\hline \hline \multicolumn{2}{|c|}{ Organic COPCs } \\
\hline \hline TPH-DRO & $\mathrm{X}$ \\
\hline PCBs & $\mathrm{X}$ \\
\hline SVOCs & $\mathrm{X}$ \\
\hline VOCs & $\mathrm{X}$ \\
\hline Pesticides & $\mathrm{X}$ \\
\hline \hline \multicolumn{2}{|c|}{ Inorganic COPCs } \\
\hline RCRA Metals & $\mathrm{X}$ \\
\hline \hline Total Beryllium & $\mathrm{X}$ \\
\hline \hline Gamma Spectroscopy & $\mathrm{X}$ \\
\hline Isotopic U & $\mathrm{X}$ \\
\hline Isotopic Pu & $\mathrm{X}$ \\
\hline Sr-90 & \\
\hline
\end{tabular}

aThe COPCs are the constituents reported from the analytical methods listed.

$X=$ Required analytical method

\section{B.2.2.3 Contaminant Characteristics}

Contaminant characteristics include, but are not limited to, solubility, density, and adsorption potential. In general, contaminants with large particle size, low solubility, high affinity for media, and/or high density can be expected to be found relatively close to release points. Contaminants with small particle size, high solubility, low affinity for media, and/or low density are found farther from release points or in low areas where evaporation of ponding will concentrate dissolved constituents. 


\section{B.2.2.4 Site Characteristics}

Site characteristics are defined by the interaction of physical, topographical, and meteorological attributes and properties. Physical properties include permeability, porosity, hydraulic conductivity, degree of saturation, sorting, chemical composition, and organic content. Topographical and meteorological properties and attributes include slope stability, precipitation frequency and amounts, precipitation runoff pathways, drainage channels and ephemeral streams, and evapotranspiration potential.

The E-MAD Facility is located in Jackass Flats in Area 25 of the NTS. Jackass Flats is between Yucca Mountain on the west and southwest and Little Skull Mountain to the south. The Calico Hills are directly north, Mid Valley and Lookout Peak are to the northeast, and Skull Mountain is to the southeast. Jackass Flats is a broad alluvial valley with alluvium and colluvium accumulations up to 1,205 ft (USGS, 1964; DOE, 1988). The alluvium in Jackass Flats is underlain by welded and semi-welded ash-flow and ash-fall tuffs of Tertiary age. Beneath the tuff layers lie Paleozoic carbonate and clastic sediments with a depth of up to 22,000 ft in some areas. The Paleozoic rocks are made up of shales, quartzites, and carbonates of lower to middle Cambrian age; carbonate and thin shale layers of middle Cambrian to Devonian age; and argillites, cherty limestones, and conglomerates of Devonian to Permian age (SNPO, 1970).

Elevation of the flats ranges from 3,600 ft in the north to 3,200 $\mathrm{ft}$ in the south, with the E-MAD Facility at 3,520 ft. Surface water flow at the north end of the E-MAD Facility drains to the southwest; at the south end of the facility, surface water drains to the south. The nearest natural water source is Topopah Springs at the head of Topopah Wash 8.7 miles to the north. The closest well to the site is J-11 Water Well, which is located approximately 9,500 ft southeast of the E-MAD Facility. The depth to groundwater as measured from this well is approximately 1,040 ft below ground surface (bgs) (DRI, 1996; USGS and DOE, 2006).

\section{B.2.2.5 Migration Pathways and Transport Mechanisms}

Migration pathways include the lateral migration of potential contaminants across surface soils/sediments and vertical migration of potential contaminants through subsurface soils. 
The E-MAD Facility is toward the middle of Jackass Flats, about $500 \mathrm{ft}$ west of Topopah Wash. Fortymile Wash, the major drainage in the area, meanders along the east base of Yucca Mountain and the west side of Jackass Flats, and eventually joins with the Amargosa River to the south. Topopah Wash, originating in the Calico Hills, bisects Jackass Flats and also joins with the Amargosa River, farther to the east (DRI, 1996). Contaminants released into the Topopah Wash are subject to much higher transport mechanisms than contaminants released to other surface areas. Topopah Wash is generally dry but is subject to infrequent, potentially intense, stormwater flows. These stormwater flow events provide an intermittent mechanism for both vertical and horizontal transport of contaminants. Contaminated sediments entrained by these stormwater events would be carried by the streamflow to locations where the flowing water loses energy and the sediments drop out. These locations are readily identifiable by hydrologists as sedimentation areas.

Infiltration and percolation of precipitation serves as a driving force for downward migration of contaminants. However, due to the low permeability of the alluvium throughout the area, high potential evapotranspiration rates, and low precipitation rates (approximately 5.72 in. per year as measured from station 4JA [ARL/SORD, 2009]), percolation of infiltrated precipitation at the NTS does not provide a significant mechanism for vertical migration of contaminants to groundwater (DOE/NV, 1992). Environmental contamination is, therefore, expected to be limited to the area near release points.

\section{B.2.2.6 Land-Use and Exposure Scenarios}

Human receptors may be exposed to COPCs through oral ingestion, inhalation, or dermal contact (absorption) of soil or debris due to inadvertent disturbance of these materials, or irradiation by radioactive materials. The land-use and exposure scenarios for CAU 114 are listed in Table B.2-3. These are based on NTS current and future land use (DOE/NV, 1998). Although CAS 25-41-03 is located in an area where structures from past activities exist, no facilities are present that would allow these to be used as an assigned work station for NTS site personnel; therefore, CAS 25-41-03 is considered an occasional use area. 
Table B.2-3

Land-Use and Exposure Scenarios

\begin{tabular}{|c|c|c|}
\hline CAS & Record of Decision Land Use Zone & Exposure Scenario \\
\hline $25-41-03$ & $\begin{array}{l}\text { Research Test and Experiment Zone } \\
\text { This area is designated for small-scale research and } \\
\text { development projects and demonstrations; pilot } \\
\text { projects; outdoor tests; and experiments for the } \\
\text { development, QA, or reliability of material and } \\
\text { equipment under controlled conditions. This zone } \\
\text { includes compatible defense and nondefense research, } \\
\text { development, and testing projects and activities. }\end{array}$ & $\begin{array}{l}\text { Occasional Use Area } \\
\text { Worker will be exposed to the site occasionally } \\
\text { (up to } 80 \text { hours per year for } 5 \text { years). Site } \\
\text { structures are not present for shelter and } \\
\text { comfort of the worker. }\end{array}$ \\
\hline
\end{tabular}




\section{B.3.0 Step 2 - Identify the Goal of the Study}

Page B-9 of B-29

Step 2 of the DQO process states how environmental data will be used in meeting objectives and solving the problem, identifies study questions or decision statement(s), and considers alternative outcomes or actions that can occur upon answering the question(s). Figure B.3-1 depicts the sequential flow of questions, answers, and action alternatives required to fulfill the objectives of the SAFER process.

\section{B.3.1 Decision Statements}

The Decision I statement is: "Is any waste present at the site likely to result in the introduction of COCs into site environmental media?” If a COC is detected, then Decision II must be resolved.

The Decision II statement is: "Is sufficient information available to meet the closure objectives?" Sufficient information to meet these closure objectives is defined to include:

- Identifying the volume of waste containing any PSM.

- The information needed to characterize IDW for disposal.

- The information needed to determine potential remediation waste types.

A corrective action will be necessary if there is a potential for wastes that are present at a site to result in the introduction of COCs into site environmental media. These wastes would be considered PSM, which is defined as waste (solid or liquid) containing contaminants that, if released to soil, would result in soil contamination exceeding a FAL. To determine whether wastes that are present at CAU 114 meet the criteria for PSM, the following conservative assumptions were made:

- Any containment of waste (e.g., fuel/oil reservoirs, pipe, concrete vaults and walls, drums) would fail at some point, and the waste would be released to the surrounding soil.

- A waste, regardless of concentration or configuration, may be assumed to be PSM and handled under a corrective action.

- Based on process knowledge and/or professional judgment, some waste may be assumed not PSM if it is clear that it could not result in soil contamination exceeding a FAL.

- If assumptions about the waste cannot be made, then the waste material will be sampled, and the results will be compared to FALs based on the following criteria: 


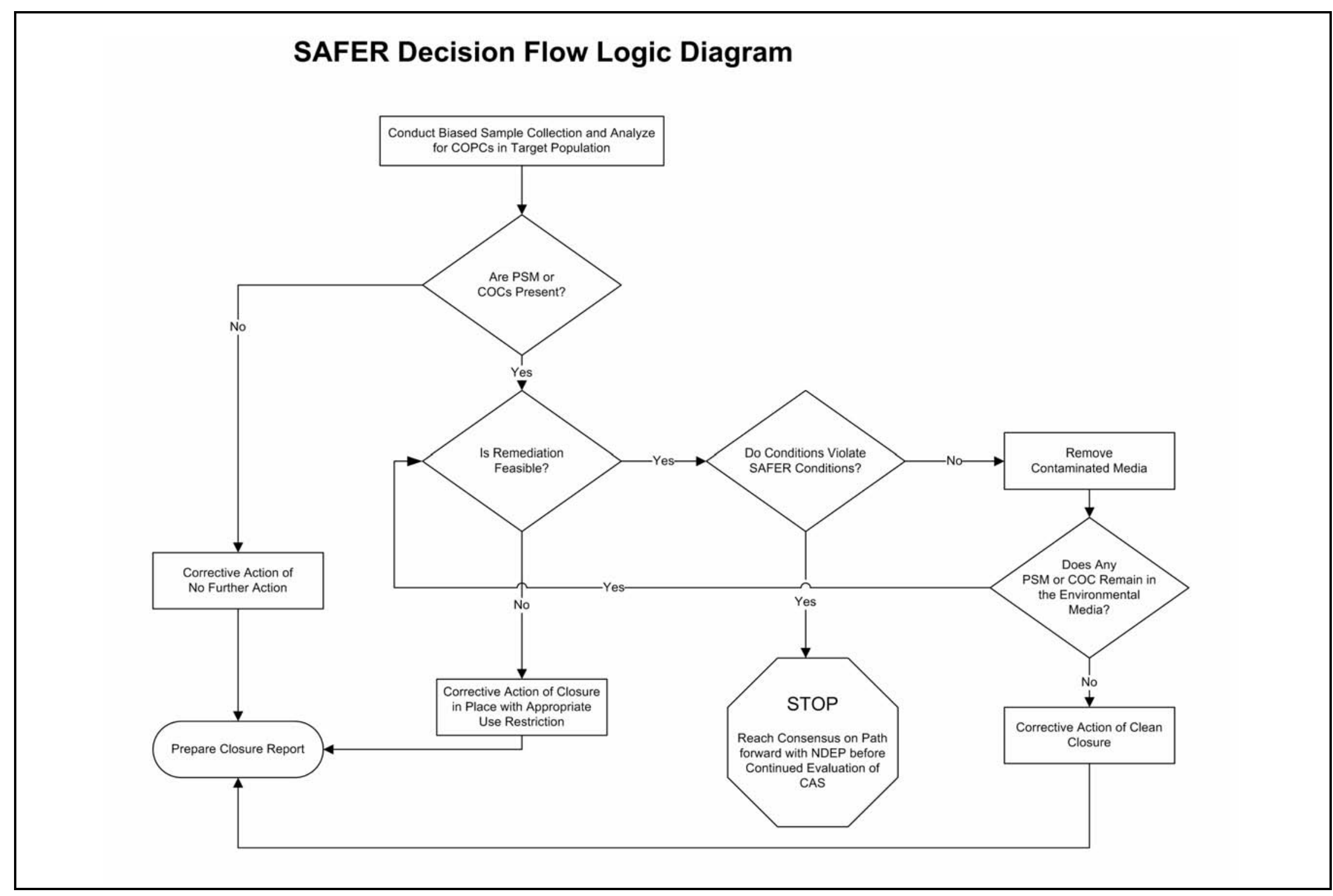

Figure B.3-1

SAFER Closure Decision Process for CAU 114 
- For non-liquid wastes, the concentration of any chemical contaminant in soil (following degradation of the waste and release of contaminants into soil) would be equal to the mass of the contaminant in the waste divided by the mass of the waste (no consideration will be given to dilution into the mass of soil).

- For non-liquid wastes, the dose resulting from radioactive contaminants in soil (following degradation of the waste and release of contaminants into soil) would be calculated using the activity of the contaminant in the waste divided by the mass of the waste (for each radioactive contaminant) and calculating the combined resulting dose using the RESRAD code (Murphy, 2004) (no consideration will be given to dilution into the mass of soil). Note: As an initial screening tool, if building materials are primarily externally contaminated and do not present a dose exceeding the FAL to a nearby worker in its current configuration, it will not be considered to meet PSM criteria.

- For liquid wastes, the resulting concentration of contaminants in the surrounding soil would be calculated based on the concentration of contaminants in the wastes and the liquid holding capacity of the soil.

For example, sludge containing a contaminant exceeding an equivalent FAL concentration would be considered to be PSM and would require a corrective action. Light ballasts with capacitors are assumed to contain PCBs based on process knowledge. These ballasts/capacitors would be assumed to be PSM without sampling and would require a corrective action.

If sufficient information is not available to meet the closure objectives, then site conditions will be re-evaluated, and additional samples will be collected (as long as the scope of the CAI is not exceeded and any CSM assumption has not been shown to be incorrect).

\section{B.3.2 Alternative Actions to the Decisions}

This section identifies actions that may be taken to solve the problem depending on the possible outcomes of the CAI.

\section{B.3.2.1 Alternative Actions to Decision I}

If no PSM associated with the CAS is detected, then further assessment of the CAS is not required, and the CAA of no further action will be selected. If a PSM is present and removal is feasible, then clean close the site by removing the PSM. If PSM is present and removal cannot be completed during the SAFER, then the remaining PSM will be closed under the alternative corrective action of closure in place. 
If contamination still exists and additional remediation would violate the conditions of the SAFER, then work will stop and a consensus reached with NDEP on the path forward before continuing the investigation of the CAS.

\section{B.3.2.2 Alternative Actions to Decision II}

If sufficient information is available to confirm that closure objectives were met, then further assessment of the CAS is not required. If sufficient information is not available to confirm that closure objectives were met, then additional samples will be collected. 


\section{B.4.0 Step 3 - Identify Information Inputs}

Step 3 of the DQO process identifies the information needed, determines sources for information, and identifies sampling and analysis methods that will allow reliable comparisons with FALs.

\section{B.4.1 Information Needs}

To resolve Decision I (determine whether a PSM is present), samples need to be collected and analyzed following these two criteria:

- Samples must be collected from wastes that are most likely to result in the release of a COC (judgmental sampling).

- The analytical suite selected must be sufficiently sensitive to identify any PSM present in the samples.

To resolve Decision II (determine whether sufficient information is available to confirm that closure objectives were met at the CAS), samples must be collected and analyzed to meet the following criteria:

- Samples of the waste or environmental media must provide sufficient information to characterize the IDW for disposal.

- Samples of the waste or environmental media must provide sufficient information to determine potential remediation waste types.

- Samples of waste must provide sufficient information to determine whether materials meet PSM criteria.

\section{B.4.2 Sources of Information}

Information to satisfy Decision I will be generated by collecting samples using hand sampling (e.g., grab, auger, bailer), power auguring, core drilling, backhoe excavation, or other appropriate sampling methods. Sampling for PSM will be conducted in areas most likely to contain a PSM (judgmental sampling). These samples will be submitted to analytical laboratories meeting the quality criteria stipulated in the Industrial Sites QAPP (NNSA/NV, 2002). Only validated data from analytical laboratories will be used to make DQO decisions. For some materials, it will be assumed that a contaminant is present based on process knowledge, and that material will be assumed to meet 
PSM criteria without the need for sampling. Radiological surveys of Building 3900 surfaces (e.g., walls, flooring, HVAC systems) will be used to determine the extent of any remaining surface contamination and to assist in evaluating the potential for a receptor to receive a dose greater than $25 \mathrm{mrem} / \mathrm{yr}$.

All waste characterization data must be sufficient to meet the quality requirements of the designated waste acceptance criteria. Waste disposal documentation, field surveys, and other appropriate information may also be used to ensure corrective actions were completed as planned.

\section{B.4.2.1 Sample Locations}

Design of the sampling approaches for CAU 114 must ensure that the data collected are sufficient for selection of the CAAs. To meet this objective, samples should be collected from locations that most likely contain a PSM, if present. These sample locations, therefore, can be selected by means of biasing factors used in judgmental sampling. Because sufficient data are available to develop a judgmental sampling plan, this approach was used to develop plans for sampling PSM. A judgmental sampling design has been developed for CAU 114 because of the presence and significance of biasing factors.

Field-survey techniques may be used to select appropriate sampling locations by providing semiquantitative data. The following field-survey methods and biasing factors may be used to select biased sample locations at CAU 114:

- Surface area walkover and radiological surveys: A radiological survey instrument will be used to detect elevated radioactivity of soil, surfaces, piping, and various other materials.

- Stains: Any discolored building material or other surfaces.

- Drums, containers, equipment or debris: Materials that may have been used at, or added to, a location, and that may have contained, or come in contact with, hazardous or radioactive substances at some point during their use.

- Preselected areas based on process knowledge of the site: Locations for which evidence such as historical photographs, experience from previous investigations, or interviewee's input, exists that a release of hazardous or radioactive substances may have occurred. 
- Preselected areas based on process knowledge of the contaminant(s): Locations that may reasonably have received contamination, selected on the basis of the chemical and/or physical properties of the contaminant(s) in that environmental setting.

- Experience and data from investigations of similar sites.

- Other biasing factors: Factors not previously defined for the CAI, but become evident once the investigation of the site is under way.

\section{B.4.2.2 Analytical Methods}

Analytical methods are available to provide the data needed to resolve the decision statements. The analytical methods and laboratory requirements (e.g., detection limits, precision, and accuracy) are provided in Tables 3-3 and 3-4. 


\section{B.5.0 Step 4 - Define the Boundaries of the Study}

Step 4 of the DQO process defines the target population of interest and its relevant spatial boundaries, specifies temporal and other practical constraints associated with sample/data collection, and defines the sampling units on which decisions or estimates will be made.

\section{B.5.1 Target Populations of Interest}

The population of interest to resolve Decision I is any location within the site that contains PSM. The populations of interest to resolve Decision II ("If PSM is present, is sufficient information available to evaluate potential CAAs?”) are:

- Environmental media or IDW that must be characterized for disposal.

- Potential remediation waste.

- Environmental media where natural attenuation or biodegradation or construction/evaluation of barriers is considered.

\section{B.5.2 Spatial Boundaries}

Spatial boundaries are the maximum lateral and vertical extent of expected contamination at each CAS. The spatial boundaries of CAS 25-41-03 are shown in Table B.5-1. Contamination found beyond these boundaries may indicate a flaw in the CSM and may require re-evaluation of the CSM before the investigation could continue. Corrective action site 25-41-03 is considered geographically independent, and intrusive activities are not intended to extend into the boundaries of neighboring CASs or existing URs from previously investigated CAUs.

Table B.5-1

Spatial Boundaries of CAS 25-41-03

\begin{tabular}{|c|c|c|c|}
\hline CAS Identifier & CAS Description & Lateral Spatial Boundary & Vertical Spatial Boundary \\
\hline \hline $25-41-03$ & EMAD Facility & $25 \mathrm{ft}$ beyond building footprint & $15 \mathrm{ft}$ bgs \\
\hline
\end{tabular}




\section{B.5.3 Practical Constraints}

Practical constraints, such as military activities, utilities, threatened or endangered animals and plants, unstable or steep terrain, and/or access restrictions, may affect the ability to investigate this site. The practical constraints associated with the CAI are summarized in Table B.5-2.

Table B.5-2

Practical Constraints for the CAU 114 Field Investigation

\begin{tabular}{|c|l|}
\hline CAS & \multicolumn{1}{|c|}{ Practical Constraints } \\
\hline \hline \multirow{2}{*}{$\begin{array}{c}25-41-03 \\
\text { EMAD Facility }\end{array}$} & $\begin{array}{l}\text { Military exercises; excavation access due to underground utilities; other access issues } \\
\text { due to aboveground structures, limited working spaces, etc. }\end{array}$ \\
\cline { 2 - 3 } & Access to confined spaces (e.g., beneath turntables, various vaults, pits, manways). \\
\hline
\end{tabular}

\section{B.5.4 Define the Sampling Units}

The scale of decision making in Decision I is defined as the CAS. Any PSM detected at any location within the CAS or CAS component will cause the determination that the CAS is contaminated and needs further evaluation. 


\section{B.6.0 Step 5 - Develop the Analytic Approach}

Step 5 of the DQO process specifies appropriate population parameters for making decisions, defines action levels, and generates an "If ... then ... else" decision rule that defines the conditions under which possible alternative actions will be chosen. This step also specifies the parameters that characterize the population of interest, specifies the FALs, and confirms that the analytical detection limits are capable of detecting FALs.

\section{B.6.1 Population Parameters}

For judgmental sampling results, the population parameter is the observed concentration of each contaminant from each individual analytical sample. Each sample result will be compared to the FALs to determine the appropriate resolution to Decision I. For Decision I, a single sample result that identifies a PSM would cause a determination that a PSM is present within the CAS.

\section{B.6.2 Action Levels}

The PALs presented in this section are to be used for site screening purposes. They are not necessarily intended to be used as cleanup action levels or FALs. However, they are useful in screening out contaminants that are not present in sufficient concentrations to warrant further evaluation and, therefore, streamline the consideration of remedial alternatives. The RBCA process used to establish FALs is described in the Industrial Sites Project Establishment of Final Action Levels (NNSA/NSO, 2006). This process conforms with NAC Section 445A.227, which lists the requirements for sites with soil contamination (NAC, 2008a). For the evaluation of corrective actions, NAC Section 445A.22705 (NAC, 2008b) requires the use of ASTM Method E1739 (ASTM, 1995) to "conduct an evaluation of the site, based on the risk it poses to public health and the environment, to determine the necessary remediation standards (i.e., FALs) or to establish that corrective action is not necessary." 
This RBCA process defines three tiers (or levels) of evaluation involving increasingly sophisticated analyses:

- Tier 1 evaluation - sample results from source areas (highest concentrations) are compared to action levels based on generic (non-site-specific) conditions (i.e., the PALs established in the SAFER Plan). The FALs may then be established as the Tier 1 action levels or the FALs may be calculated using a Tier 2 evaluation.

- Tier 2 evaluation - conducted by calculating Tier 2 SSTLs using site-specific information as inputs to the same or similar methodology used to calculate Tier 1 action levels. The Tier 2 SSTLs are then compared to individual sample results from reasonable points of exposure (as opposed to the source areas as is done in Tier 1) on a point-by-point basis. Total petroleum hydrocarbon concentrations will not be used for risk-based decisions under Tier 2 or Tier 3. Rather, the individual chemicals of concern will be compared to the SSTLs.

- Tier 3 evaluation - conducted by calculating Tier 3 SSTLs on the basis of more sophisticated risk analyses using methodologies described in Method E1739 that consider site-, pathway-, and receptor-specific parameters.

The comparison of laboratory results to FALs and the evaluation of potential corrective actions will be included in the investigation report. The FALs will be defined (along with the basis for their definition) in the investigation report.

\section{B.6.2.1 Chemical PALs}

Except as noted herein, the chemical PALs are defined as the EPA Region 9 Superfund preliminary RSLs for chemical contaminants in industrial soils (EPA, 2009). Background concentrations for RCRA metals and zinc will be used instead of RSLs when natural background concentrations exceed the RSL, as is often the case with arsenic on the NTS. Background is considered the mean plus two standard deviations of the mean for sediment samples collected by the Nevada Bureau of Mines and Geology throughout the Nevada Test and Training Range (formerly the Nellis Air Force Range) (NBMG, 1998; Moore, 1999). For detected chemical COPCs without established RSLs, the protocol used by the EPA Region 9 in establishing RSLs (or similar) will be used to establish PALs (EPA, 2009). If used, this process will be documented in the CR.

\section{B.6.2.2 Total Petroleum Hydrocarbon PALs}

The PAL for TPH is $100 \mathrm{mg} / \mathrm{kg}$ as listed in NAC 445A.2272 (NAC, 2008c). 


\section{B.6.2.3 Radionuclide PALs}

The PALs for radiological contaminants are based on the NCRP Report No. 129 recommended screening limits for construction, commercial, industrial land-use scenarios (NCRP, 1999) scaled to 25-mrem/yr dose constraint (Murphy, 2004) and the generic guidelines for residual concentration of radionuclides in DOE Order 5400.5 (DOE, 1993). These PALs are based on the construction, commercial, and industrial land-use scenario provided in the guidance and are appropriate for the NTS based on future land use scenarios as presented in Section B.2.2.6.

\section{B.6.3 Decision Rules}

The decision rules applicable to both Decision I and Decision II are:

- If COC contamination is inconsistent with the CSM or extends beyond the spatial boundaries identified in Section B.5.2, then work will be suspended and the investigation strategy will be reconsidered, else the decision will be to continue sampling to define the extent.

The decision rules for Decision I are:

- If the population parameter of any COPC in the Decision I population of interest (defined in Section B.5.1) exceeds the corresponding PSM criteria, then that waste is identified as a PSM, and the PSM will be removed.

- If no PSM associated with a release from the CAS is detected, then further assessment of the CAS is not required, and the CAA of no further action will be selected. If a PSM associated with a release from the CAS is detected and removal is feasible, then clean close the site by removing the PSM. If the presence of PSM has been determined and removal is not feasible, then the remaining contamination will be closed under the alternative corrective action of closure in place.

The decision rules for Decision II are:

- If valid analytical results are available for the waste characterization samples defined in Section B.8.0, then the decision will be that sufficient information exists to characterize the IDW for disposal and determine potential remediation waste types, else collect additional waste characterization samples. 


\section{B.7.0 Step 6 - Specify Performance or Acceptance Criteria}

Step 6 of the DQO process defines the decision hypotheses, specifies controls against false rejection and false acceptance decision errors, examines consequences of making incorrect decisions from the test, and places acceptable limits on the likelihood of making decision errors.

\section{B.7.1 Decision Hypotheses}

The baseline condition (i.e., null hypothesis) and alternative condition for Decision I are:

- $\quad$ Baseline condition - A PSM is present.

- Alternative condition - A PSM is not present.

Decisions and/or criteria have false negative or false positive errors associated with their determination. The impact of these decision errors and the methods that will be used to control these errors are discussed in the following subsections. In general terms, confidence in DQO decisions based on judgmental sampling results will be established qualitatively by:

- Developing and achieving concurrence of CSMs (based on process knowledge) by stakeholder participants during the DQO process.

- $\quad$ Conducting validity testing of CSMs based on investigation results.

- $\quad$ Evaluating data quality based on DQI parameters.

\section{B.7.2 False Negative Decision Error}

The false negative decision error would mean deciding that a PSM is not present when it actually is (Decision I). The potential consequence is an increased risk to human health and the environment.

\section{B.7.2.1 False Negative Decision Error for Judgmental Sampling}

In judgmental sampling, the selection of the number and location of samples is based on knowledge of the feature or condition under investigation and professional judgment (EPA, 2002). Judgmental sampling conclusions about the target population depend upon the validity and accuracy of professional judgment. 
The false negative decision error (where consequences are more severe) for judgmental sampling designs is controlled by meeting these criteria:

- For Decision I, having a high degree of confidence that the sample locations selected will identify PSM if present anywhere within the CAS.

- Having a high degree of confidence that analyses conducted will be sufficient to detect any PSM present in the samples.

- Having a high degree of confidence that the dataset is of sufficient quality and completeness.

To satisfy the first criterion, Decision I samples must be collected in areas most likely to contain a PSM. The following characteristics must be considered to control decision errors for the first criterion:

- Source and location of release

- Chemical nature and fate properties

- Physical transport pathways and properties

- Hydrologic drivers

These characteristics were considered during the development of the CSMs and selection of sampling locations. The field-survey methods and biasing factors listed in Section B.4.2.1 will be used to further ensure that appropriate sampling locations are selected to meet these criteria. Radiological survey instruments and field-screening equipment will be calibrated and checked in accordance with the manufacturer's instructions and approved procedures. The investigation report will present an assessment on the DQI of representativeness that samples were collected from those locations that best represent the populations of interest as defined in Section B.5.1.

To satisfy the second criterion, Decision I samples will be analyzed for the chemical and radiological parameters listed in Section 3.2. The DQI of sensitivity will be assessed for all analytical results to ensure that all sample analyses had measurement sensitivities (detection limits) that were less than or equal to the corresponding FALs. If this criterion is not achieved, the affected data will be assessed (for usability and potential impacts on meeting site characterization objectives) in the investigation report.

To satisfy the third criterion, the entire dataset, as well as individual sample results, will be assessed against the DQIs of precision, accuracy, comparability, and completeness as defined in the Industrial 
Sites QAPP (NNSA/NV, 2002) and in Section 7.2 of this SAFER Plan. The DQIs of precision and accuracy will be used to assess overall analytical method performance as well as the need to potentially “flag” (qualify) individual contaminant results when corresponding QC sample results are not within the established control limits for precision and accuracy. Data qualified as estimated for reasons of precision or accuracy may be considered to meet the constituent performance criteria based on an assessment of the data. The DQI of completeness will be assessed to ensure that all data needs identified in the DQO have been met. The DQI of comparability will be assessed to ensure that all analytical methods used are equivalent to standard EPA methods so that results will be comparable to regulatory action levels that have been established using those procedures. Strict adherence to established procedures and QA/QC protocol protects against false negative decision errors. Site-specific DQIs are discussed in more detail in Section 7.2 of this SAFER Plan.

To provide information for the assessment of the DQIs of precision and accuracy, the following QC samples will be collected as required by the Industrial Sites QAPP (NNSA/NV, 2002):

- $\quad$ Field duplicates (1 per 20 samples)

- $\quad$ Laboratory QC samples (1 per 20 samples)

\section{B.7.3 False Positive Decision Error}

The false positive decision error would mean deciding that a PSM is present when it is not, resulting in increased costs for unnecessary sampling and analysis.

False positive results are typically attributed to laboratory and/or sampling/handling errors that could cause cross contamination. To control against cross contamination, decontamination of sampling equipment will be conducted according to established and approved procedures and only clean sample containers will be used. To determine whether a false positive analytical result may have occurred, the following QC samples will be collected as required by the Industrial Sites QAPP (NNSA/NV, 2002):

- Trip blanks (1 per sample cooler containing VOC samples)

- Equipment blanks (1 per sampling event for each type of decontamination method)

- Source blanks (1 per uncharacterized lot of source water)

- Field blanks (minimum of 1 per CAS, additional if field conditions change) 


\section{B.8.0 Step 7 - Develop the Plan for Obtaining Data}

Step 7 of the DQO process selects and documents a design that will yield data that will best achieve performance or acceptance criteria. Judgmental sampling schemes will be implemented to select sample locations and evaluate analytical results for CAU 114. Section B.8.1 contains general information about collecting Decision I samples under a judgmental sampling design. Section B.8.2 provides the specific sampling design for CAS 25-41-03.

\section{B.8.1 Decision I Sampling}

A judgmental sampling design will be implemented for CAU 114. Because individual sample results, rather than an average concentration, will be used to compare to the FALs, statistical methods to generate site characteristics will not be used. Adequate representativeness of the entire target population may not be a requirement to developing a sampling design. If good prior information is available on the target site of interest, then the sampling may be designed to collect samples only from areas known to have the highest concentration levels on the target site. If the observed concentrations from these samples are below PSM criteria, then a decision can be made that the site contains safe levels of the contaminant without the samples being truly representative of the entire area (EPA, 2006).

All sample locations will be selected to satisfy the DQI of representativeness in that samples collected from selected locations will best represent the populations of interest as defined in Section B.5.1. To meet this criterion for judgmentally sampled sites, a biased sampling strategy will be used for Decision I samples to target areas with the highest potential for contamination, if it is present anywhere in the CAS. Sample locations will be determined based on process knowledge, previously acquired data, or the field-survey methods and biasing factors listed in Section B.4.2.1. The Site Supervisor has the discretion to modify the judgmental sample locations, but only if the modified locations meet the decision needs and criteria stipulated in this DQO.

\section{B.8.2 Sampling Design}

This section discusses the specific sampling design for CAS 25-41-03. This CAS consists of the potential releases to soil associated with historic operations at Building 3900. Any potential releases 
identified during the field investigation that are associated with Building 3900 operations and support activities will be included in the scope of the CAI.

The Decision I sampling strategy at this CAS will involve the collection of PSM samples.

Table B.8-1 lists the known or anticipated PSMs at Building 3900 and indicates which materials will be sampled and which will be assumed PSM. Samples will be collected from materials within Building 3900 that are suspected to contain COPCs and that may cause the future release of a COC to environmental media. Materials within Building 3900 that have been assumed to meet PSM criteria will be removed and disposed of without the need for environmental sampling. For the process water systems (chilled water, condenser water, heating hot water, potable cold water, potable hot water, process cold water, and process hot water), it is assumed that the fluids would not meet PSM criteria, and samples will not be required. It is also anticipated that concrete samples of floor and wall surfaces may be collected using core drilling techniques based on identified elevated radioactivity or other biasing factors. Samples of material removed during SAFER activities will be taken for waste characterization purposes, as such material is identified.

Table B.8-1

Known or Anticipated Potential Source Materials

(Page 1 of 2 )

\begin{tabular}{|c|c|c|c|}
\hline Potential Source $^{a}$ & Material & Contaminants $^{\mathrm{b}}$ & SamplelAssumed \\
\hline $\begin{array}{l}\text { PCB-containing ballast } \\
\text { capacitors }\end{array}$ & Ballast material & PCBs & Assumed \\
\hline Excess chemicals & Chemicals & $\begin{array}{l}\text { VOCs, svOCs, } \\
\text { RCRA Metals }\end{array}$ & Sample \\
\hline HEPA filters & Filter paper & Radiological & Sample \\
\hline Fluorescent light bulbs & Gases, RCRA Metals & RCRA Metals & Assumed \\
\hline Freon & Gases & RCRA Metals & Assumed \\
\hline Mercury vapor lights & Gases, RCRA Metals & RCRA Metals & Assumed \\
\hline Sodium vapor lights & Gases & RCRA Metals & Assumed \\
\hline Radiological check sources & Metals & Radiological & Sample \\
\hline DU counterweights & Metals & Radiological & Assumed \\
\hline Lead-containing fuses & Metals & RCRA Metals & Assumed \\
\hline Lead-acid batteries & Metals & RCRA Metals & Assumed \\
\hline Mercury-containing items & Metals & RCRA Metals & Assumed \\
\hline
\end{tabular}


Table B.8-1

\section{Known or Anticipated Potential Source Materials}

(Page 2 of 2)

\begin{tabular}{|c|c|c|c||}
\hline Potential Source $^{\mathbf{a}}$ & Material & Contaminants $^{\text {b }}$ & Sample/Assumed \\
\hline \hline Circuit boards & Metals & RCRA Metals, Radiological & Assumed \\
\hline Lead-glass windows & Metals & RCRA Metals, Radiological & Assumed \\
\hline Lead solids/shielding & Metals & RCRA Metals, Radiological & Assumed \\
\hline Mineral oil & Oils & Radiological & Sample \\
\hline Diesel fuel & Oils & VOCs, SVOCs, Radiological & Sample \\
\hline $\begin{array}{c}\text { Compressor, gear, and } \\
\text { hydraulic oils }\end{array}$ & Oils & VOCs, SVOCs, PCBs, & Sample \\
\hline Motor oil & Oils & $\begin{array}{c}\text { VOCs, SVOCs, PCBs, } \\
\text { RCRA Metals }\end{array}$ & Sample \\
\hline Metallurgy Lab drains & Solid, liquid, sludge & $\begin{array}{c}\text { Radiological, RCRA Metals, } \\
\text { VOCs, SVOCs }\end{array}$ & Sample \\
\hline
\end{tabular}

${ }^{\mathrm{a}}$ Other wastes may be identified during the CAI.

${ }^{\mathrm{b}}$ The listed contaminants are the best available based on site history and process knowledge. Actual analytical suites will be determined in the field on a case-by-case basis based on process knowledge, field conditions, etc.

Note: Sample vs. assumed - Some PSMs will be assumed that a contaminant is present and be treated as such with no samples being collected or analyzed. Other PSMs will be sampled to determine whether and what contaminants are present.

The number and locations of Decision I samples to be collected at Building 3900 will be based on biasing factors identified based on radiological surveys and visual inspections of the interior of the building, as well as other biasing factors listed in Section B.4.2.1. Radiological surveys of Building 3900 surfaces (e.g., walls, flooring, HVAC systems) will be used to determine the extent of any remaining surface contamination and its potential to expose a receptor to a dose greater than $25 \mathrm{mrem} / \mathrm{yr}$.

Potential pathways to environmental media from Building 3900 will also be determined by investigating any waste and drain systems (e.g., radioactive waste system, sanitary sewer system) associated with Building 3900. For any portions of waste or drain systems that were not previously investigated under another CAU, the investigation of that system may be incorporated into CAS 25-41-03 based on process knowledge. 


\section{B.9.0 References}

ARL/SORD, see Air Resources Laboratory/Special Operations and Research Division.

ASTM, see American Society for Testing and Materials.

Air Resources Laboratory/Special Operations and Research Division. 2009. NTS Climatological Rain Gauge Data. As accessed at http://www.sord.nv.doe.gov/home_climate_rain.htm on 4 May.

American Society for Testing and Materials. 1995 (reapproved 2002). Standard Guide for Risk-Based Corrective Action Applied at Petroleum Release Sites, ASTM E1739 - 95(2002). Philadelphia, PA.

DOE, see U.S. Department of Energy.

DOE/NV, see U.S. Department of Energy, Nevada Operations Office.

DRI, see Desert Research Institute.

Desert Research Institute. 1996. A Historical Evaluation of the Engine Maintenance Assembly and Disassembly Facility, Area 25, Nevada Test Site, Nye County, Nevada, SR082696-1. Prepared by C.M. Beck, H. Drollinger, R. Jones, D. Winslow, and N.G. Goldenberg. Las Vegas, NV.

EPA, see U.S. Environmental Protection Agency.

Moore, J., Science Applications International Corporation. 1999. Memorandum to M Todd (SAIC) titled "Background Concentrations for NTS and TTR Soil Samples,” 3 February. Las Vegas, NV: IT Corporation.

Murphy, T., Bureau of Federal Facilities. 2004. Letter to R. Bangerter (NNSA/NSO) titled "Review of Industrial Sites Project Document Guidance for Calculating Industrial Sites Project Remediation Goals for Radionuclides in Soil Using the Residual Radiation (RESRAD) Computer Code.” 19 November. Las Vegas, NV.

NAC, see Nevada Administrative Code.

NBMG, see Nevada Bureau of Mines and Geology.

NCRP, see National Council on Radiation Protection and Measurements.

NNSA/NSO, see U.S. Department of Energy, National Nuclear Security Administration Nevada Site Office. 
NNSA/NV, see U.S. Department of Energy, National Nuclear Security Administration Nevada Operations Office.

National Council on Radiation Protection and Measurements. 1999. Recommended Screening Limits for Contaminated Surface Soil and Review of Factors Relevant to Site-Specific Studies, NCRP Report No. 129. Bethesda, MD.

Nevada Administrative Code. 2008a. NAC 445A.227, “Contamination of Soil: Order by Director for Corrective Action; Factors To Be Considered in Determining Whether Corrective Action Required.” As accessed at http://www.leg.state.nv.us/nac on 4 May 2009.

Nevada Administrative Code. 2008b. NAC 445A.22705, "Contamination of Soil: Evaluation of Site by Owner or Operator; Review of Evaluation by Division.” As accessed at http://www.leg.state.nv.us/nac on 4 May 2009.

Nevada Administrative Code. 2008c. NAC 445A.2272, “Contamination of Soil: Establishment of Action Levels.” As accessed at http://www.leg.state.nv.us/nac on 4 May 2009.

Nevada Bureau of Mines and Geology. 1998. Mineral and Energy Resource Assessment of the Nellis Air Force Range, Open-File Report 98-1. Reno, NV.

SNPO, see Space Nuclear Propulsion Office.

Space Nuclear Propulsion Office. 1970. NRDS Master Plan, 1969-1970. Prepared by IT Corporation. Las Vegas, NV.

USGS, see U.S. Geological Survey.

USGS and DOE, see U.S. Geological Survey and U.S. Department of Energy.

U.S. Department of Energy. 1988. Environmental Survey Preliminary Report, Nevada Test Site, Mercury, Nevada, DOE/EH/OEV-15P. April. Washington, DC: Environmental, Safety, and Health Office of Environmental Audit.

U.S. Department of Energy. 1993. Radiation Protection of the Public and the Environment, DOE Order 5400.5, Change 2. Washington, DC: U.S. Government Printing Office.

U.S. Department of Energy, National Nuclear Security Administration Nevada Operations Office. 2002. Industrial Sites Quality Assurance Project Plan, Nevada Test Site, Nevada, Rev. 3, DOE/NV--372. Las Vegas, NV.

U.S. Department of Energy, National Nuclear Security Administration Nevada Site Office. 2006. Industrial Sites Project Establishment of Final Action Levels, DOE/NV--1107, Rev. 0. Las Vegas, NV. 
U.S. Department of Energy, Nevada Operations Office. 1992. Remedial Investigation and Feasibility Study for the Plutonium Contaminated Soils at Nevada Test Site, Nellis Air Force Range and Tonopah Test Range. April. Las Vegas, NV.

U.S. Department of Energy, Nevada Operations Office. 1998. Nevada Test Site Resource Management Plan, DOE/NV--518. Las Vegas, NV.

U.S. Environmental Protection Agency. 2002. Guidance for Quality Assurance Project Plans, EPA QA/G5, EPA/240/R-02/009. Washington, DC: Office of Environmental Information.

U.S. Environmental Protection Agency. 2006. Guidance on Systematic Planning Using the Data Quality Objectives Process, EPA QA/G-4, EPA/240/B-06/001. Washington, DC: Office of Environmental Information.

U.S. Environmental Protection Agency. 2009. Region 9: Superfund, Regional Screening Levels (Formerly PRGs) for Chemical Contaminants. As accessed at http://www.epa.gov/region09/superfund/prg on 4 May. Prepared by EPA Office of Superfund and Oak Ridge National Laboratory.

U.S. Geological Survey. 1964. Geology of the Jackass Flats Quadrangle, Nye County, Nevada. Prepared by E.J. McKay and W.P. Williams.

U.S. Geological Survey and U.S. Department of Energy. 2006. USGS/U.S. DOE Cooperative Studies in Nevada: J-11 WW Web Page. As accessed at http://nevada.usgs.gov/doe_nv/ntsmap.htm on 4 May 2009. 


\title{
Appendix C
}

\section{Nevada Division of Environmental Protection Comments}

\author{
(11 Pages)
}




\section{NEVADA ENVIRONMENTAL RESTORATION PROJECT DOCUMENT REVIEW SHEET}

\begin{tabular}{|c|c|c|c|c|c|c|}
\hline \multicolumn{2}{|c|}{ 1. Document Title/Number: } & \multicolumn{2}{|c|}{$\begin{array}{l}\text { Draft Streamlined Approach for Environmental Restoration Plan for CAU 114: } \\
\text { Area } 25 \text { EMAD Facility, Nevada Test Site, Nevada }\end{array}$} & 2. Document Date: & \multicolumn{2}{|l|}{$6 / 29 / 2009$} \\
\hline \multicolumn{2}{|l|}{ 3. Revision Number: } & 0 & & 4. Originator/Organization: & \multicolumn{2}{|l|}{ Stoller-Navarro } \\
\hline \multicolumn{2}{|c|}{$\begin{array}{l}\text { 5. Responsible NNSA/NSO Federal } \\
\text { Sub-Project Director: }\end{array}$} & \multicolumn{2}{|l|}{ Kevin J. Cabble } & 6. Date Comments Due: & \multicolumn{2}{|l|}{$7 / 29 / 2009$} \\
\hline \multicolumn{2}{|l|}{ 7. Review Criteria: } & \multicolumn{2}{|l|}{ Full } & & & \\
\hline \multicolumn{2}{|c|}{ 8. Reviewer/Organization/Phone No: } & Jeff MacDougall and John Wong, NDEP, 486-2850, extensions & 233 and 245 & 9. Reviewer's Signature: & & \\
\hline $\begin{array}{l}\text { 10. Comment } \\
\text { Number/Locatio }\end{array}$ & 11. Type* & 12. Comment & \multicolumn{3}{|c|}{ 13. Comment Response } & 14. Accept \\
\hline $\begin{array}{l}\text { 1.) Section 2.1.7, } \\
\text { Page } 21\end{array}$ & Mandatory & $\begin{array}{l}\text { Specify, perhaps in a diagram, the locations from where } \\
\text { bulk soil samples (February 2003) and swipe samples } \\
\text { (September 2003) were collected - the general location/area } \\
\text { of sample collection is pertinent with respect to interpreting } \\
\text { the significance of the available characterization information. }\end{array}$ & \multicolumn{3}{|c|}{$\begin{array}{l}\text { Revise the last } 2 \text { paragraphs of Section } 2.1 .7 \text { as follows: } \\
\text { The NTS management and operating (M\&O) contractor } \\
\text { collected soil and and swipe samples at the E-MAD Facility } \\
\text { in } 2003 \text {. Seven bulk soil samples were collected (February } \\
2003 \text { ) and analyzed for beryllium. The results of the } \\
\text { analyses ranged from } 0.0628 \text { parts per million (ppm) to } \\
0.4630 \mathrm{ppm} \text { (Spezialetti, } 2007 \text { ). Fifteen swipe samples were } \\
\text { collected (September } 2003 \text { ) and analyzed for arsenic, } \\
\text { beryllium, cadmium, chromium, and lead. The analytical } \\
\text { results for arsenic ranged from } 0.7 \text { micrograms per } 100 \\
\text { square centimeters ( } \mu \mathrm{g} / 100 \mathrm{~cm} 2 \text { ) to } 5.0 \mu \mathrm{g} / 100 \mathrm{~cm} 2 \text {. The } \\
\text { analytical results for beryllium ranged from } 0.0 \mu \mathrm{g} / 100 \mathrm{~cm} 2 \\
\text { to } 0.13 \mu \mathrm{g} / 100 \mathrm{~cm} 2 \text {. The analytical results for cadmium } \\
\text { ranged from } 0.03 \mu \mathrm{g} / 100 \mathrm{~cm} 2 \text { to } 9.3 \mu \mathrm{g} / 100 \mathrm{~cm} 2 \text {. The } \\
\text { analytical results for chromium ranged from } 0.66 \mu \mathrm{g} / 100 \mathrm{~cm} 2 \\
\text { to } 1,800 \mu \mathrm{g} / 100 \mathrm{~cm} 2 \text {. The analytical results for lead ranged } \\
\text { from } 2.0 \mu \mathrm{g} / 100 \mathrm{~cm} 2 \text { to } 3,700 \mu \mathrm{gg} / 100 \mathrm{~cm} 2(\mathrm{Spezialetti,}, 2007) \text { ). } \\
\text { Specific sample locations for the } 2003 \text { data are unknown, } \\
\text { and the results can only be used to assess initial } \\
\text { requirements for personnel protection. }\end{array}$} & \\
\hline
\end{tabular}




\section{NEVADA ENVIRONMENTAL RESTORATION PROJECT DOCUMENT REVIEW SHEET}

\begin{tabular}{|c|c|c|c|c|c|c|}
\hline \multicolumn{2}{|c|}{ 1. Document Title/Number: } & \multicolumn{2}{|c|}{$\begin{array}{l}\text { Draft Streamlined Approach for Environmental Restoration Plan for CAU 114: } \\
\text { Area } 25 \text { EMAD Facility, Nevada Test Site, Nevada }\end{array}$} & 2. Document Date: & \multicolumn{2}{|l|}{$6 / 29 / 2009$} \\
\hline \multicolumn{2}{|l|}{ 3. Revision Number: } & \multicolumn{2}{|l|}{0} & 4. Originator/Organization: & \multicolumn{2}{|l|}{ Stoller-Navarro } \\
\hline \multicolumn{2}{|c|}{$\begin{array}{l}\text { 5. Responsible NNSA/NSO Federal } \\
\text { Sub-Project Director: }\end{array}$} & \multicolumn{2}{|l|}{ Kevin J. Cabble } & 6. Date Comments Due: & \multicolumn{2}{|l|}{ 7/29/2009 } \\
\hline \multicolumn{2}{|l|}{ 7. Review Criteria: } & \multicolumn{2}{|l|}{ Full } & & & \\
\hline \multicolumn{2}{|c|}{ 8. Reviewer/Organization/Phone No: } & : Jeff MacDougall and John Wong, NDEP, 486-2850, extensions & 233 and 245 & 9. Reviewer's Signature: & & \\
\hline $\begin{array}{l}\text { 10. Comment } \\
\text { Number/Locatio }\end{array}$ & 11. Type* & 12. Comment & \multicolumn{3}{|c|}{ 13. Comment Response } & 14. Accept \\
\hline $\begin{array}{l}\text { 2.) Section 2.3.1, } \\
\text { Pages } 32-38\end{array}$ & Mandatory & $\begin{array}{l}\text { Include appropriate discussion on CAU } 119 \text { and CAS } 25-01- \\
14 \text { since this site is within the footprint of Building } 3900 \\
\text { (CAS 25-41-03). }\end{array}$ & \multicolumn{3}{|c|}{$\begin{array}{l}\text { The following text has been inserted at the end of Section } \\
\text { 2.3. } \\
\text { Although CAS 25-01-14 (CAU 119) is located within the } \\
\text { footprint of the E-MAD Facility, it is not believed to have any } \\
\text { impact on CAS 25-41-03. Corrective Action Site 25-01-14 } \\
\text { was clean closed under the housekeeping corrective action } \\
\text { process (DOE/NV, 2000a). }\end{array}$} & \\
\hline
\end{tabular}




\section{NEVADA ENVIRONMENTAL RESTORATION PROJECT DOCUMENT REVIEW SHEET}

\begin{tabular}{|c|c|c|c|c|c|c|}
\hline \multicolumn{2}{|c|}{ 1. Document Title/Number: } & \multicolumn{2}{|c|}{$\begin{array}{l}\text { Draft Streamlined Approach for Environmental Restoration Plan for CAU 114: } \\
\text { Area } 25 \text { EMAD Facility, Nevada Test Site, Nevada }\end{array}$} & \multirow{2}{*}{\begin{tabular}{|l|} 
2. Document Date: \\
4. Originator/Organization: \\
\end{tabular}} & \multicolumn{2}{|l|}{$6 / 29 / 2009$} \\
\hline \multicolumn{2}{|l|}{ 3. Revision Number: } & 0 & & & Stoller-Navarro & \\
\hline \multicolumn{2}{|c|}{$\begin{array}{l}\text { 5. Responsible NNSA/NSO Federal } \\
\text { Sub-Project Director: }\end{array}$} & Kevin J. Cabble & & 6. Date Comments Due: & $7 / 29 / 2009$ & \\
\hline \multicolumn{2}{|l|}{ 7. Review Criteria: } & Full & & & & \\
\hline \multicolumn{2}{|c|}{ 8. Reviewer/Organization/Phone No: } & \begin{tabular}{l|l}
$:$ Jeff MacDougall and John Wong, NDEP, 486-2850, extensions
\end{tabular} & 233 and 245 & 9. Reviewer's Signature: & & \\
\hline \begin{tabular}{|l} 
10. Comment \\
Number/Locatio
\end{tabular} & 11. Type* & 12. Comment & \multicolumn{3}{|c|}{ 13. Comment Response } & 14. Accept \\
\hline $\begin{array}{l}\text { 3.) Section } 4.0 \text {, } \\
\text { Page } 53\end{array}$ & Mandatory & $\begin{array}{l}\text { In the first paragraph of this section, general objectives are } \\
\text { described; it may also be appropriate to specify the course } \\
\text { of action to be taken if remediation is found to be not } \\
\text { feasible. }\end{array}$ & \multicolumn{3}{|c|}{$\begin{array}{l}\text { The course of action to be taken if remediation is found to } \\
\text { be not feasible was added to this paragraph. Revised text } \\
\text { removes the term "feasible" and makes clear that a hold } \\
\text { point will be implemented should NNSA not be able to } \\
\text { complete the planned activity. In this case, NDEP will be } \\
\text { involved with NNSA to determine the appropriate path } \\
\text { forward. } \\
\text { For consistency, this correction was made throughout the } \\
\text { document wherever the term "feasible" was used. To } \\
\text { implement this clarification, the following changes were } \\
\text { made throughout the document. } \\
\text { Revised 1st paragraph of Section 4.0, Page } 53 \text { as follows: } \\
\text { This section of the SAFER Plan provides a description of } \\
\text { the field activities and closure objectives for CAU } 114 \text {. The } \\
\text { objectives for the field activities are to determine whether } \\
\text { COCs or PSMs exist. If remediation cannot be } \\
\text { accomplished during the SAFER, then the extent of COCs } \\
\text { will be determined so that closure alternatives may be } \\
\text { implemented. If clean closure cannot be accomplished } \\
\text { during the SAFER, then a hold point will have been reached } \\
\text { and NDEP will be consulted to determine whether the } \\
\text { remaining contamination will be closed under the alternative } \\
\text { corrective action of closure in place. All sampling activities } \\
\text { will be conducted in compliance with the Industrial Sites }\end{array}$} & \\
\hline
\end{tabular}




\section{NEVADA ENVIRONMENTAL RESTORATION PROJECT DOCUMENT REVIEW SHEET}

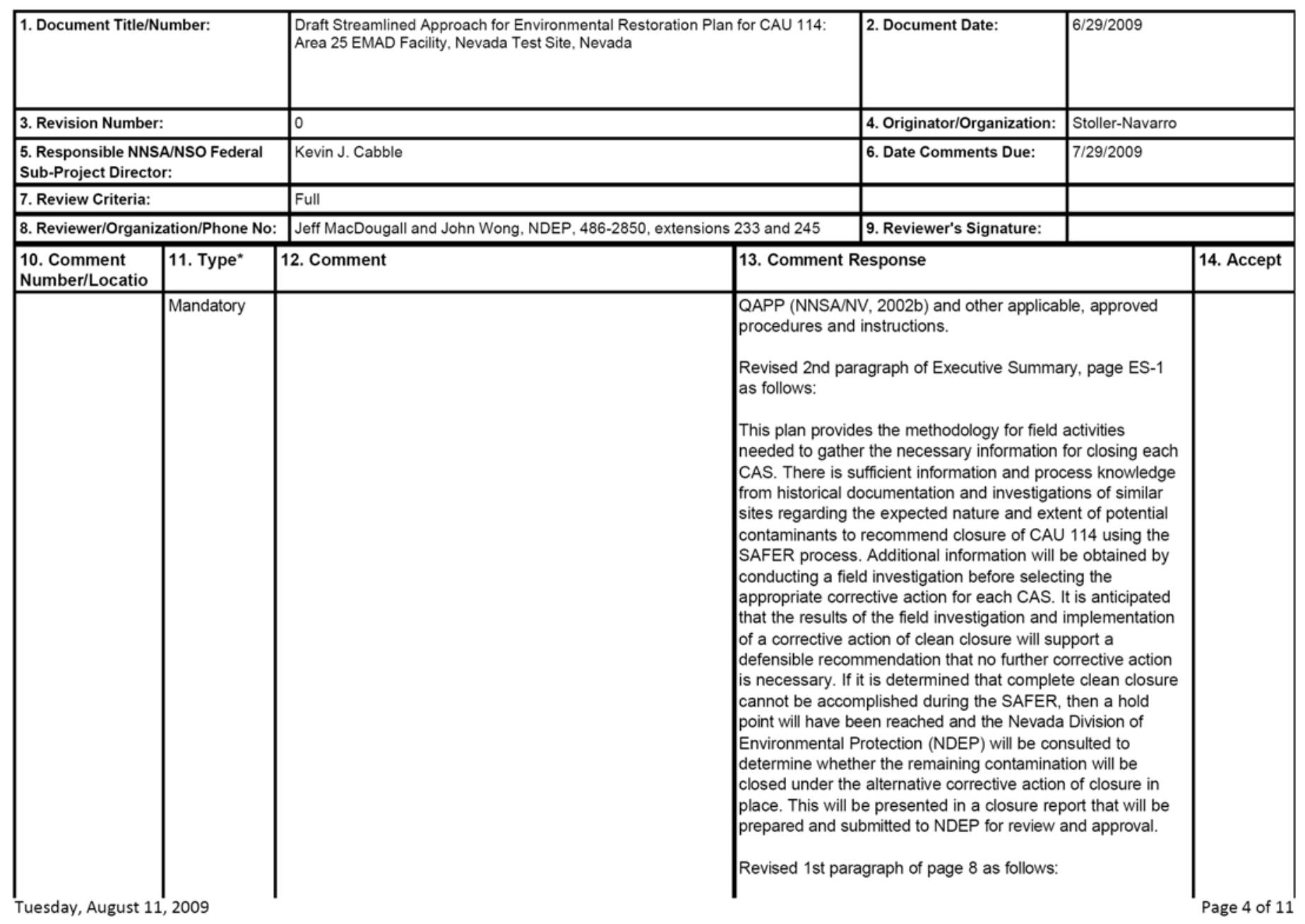




\section{NEVADA ENVIRONMENTAL RESTORATION PROJECT DOCUMENT REVIEW SHEET}

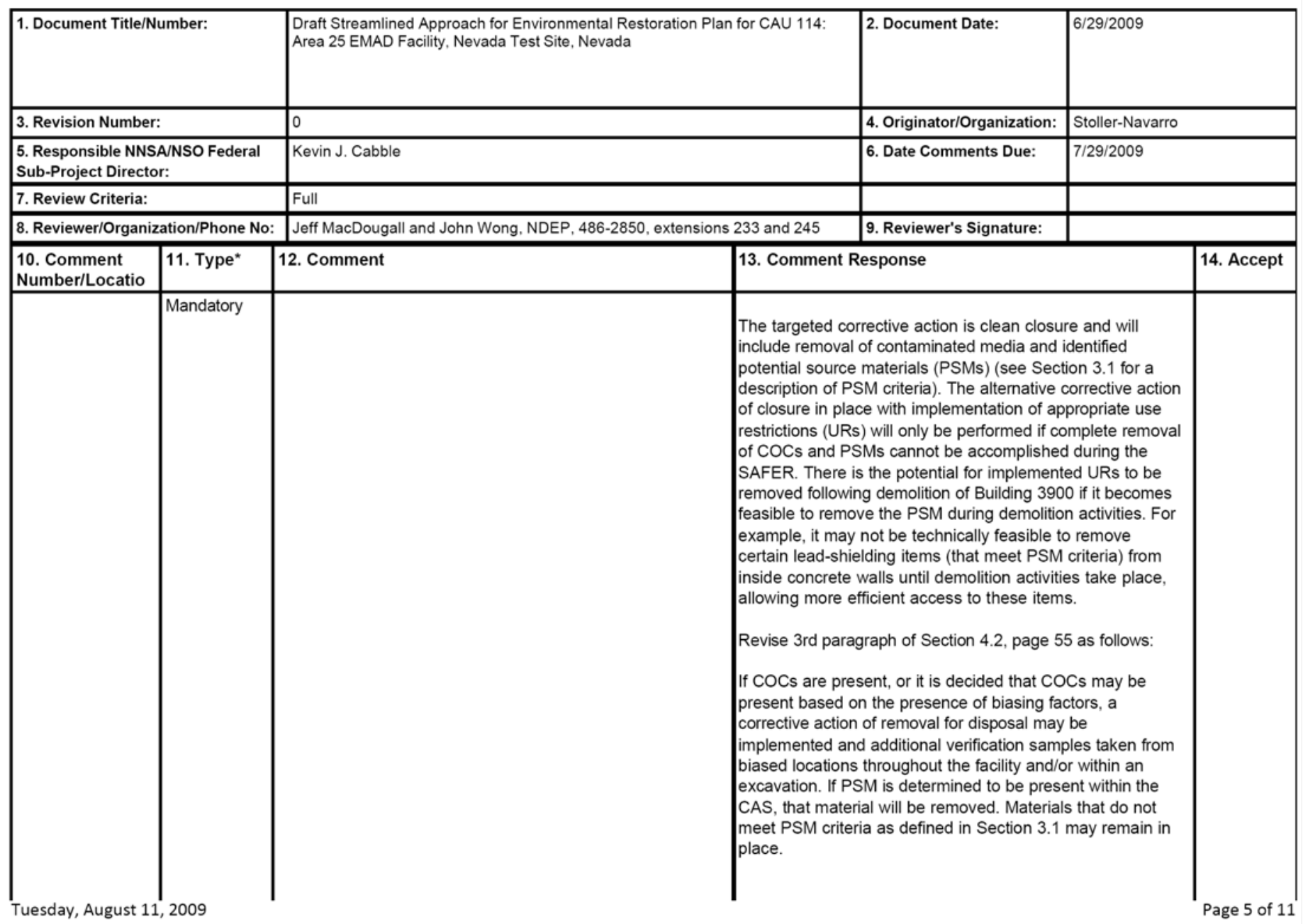




\section{NEVADA ENVIRONMENTAL RESTORATION PROJECT}

DOCUMENT REVIEW SHEET

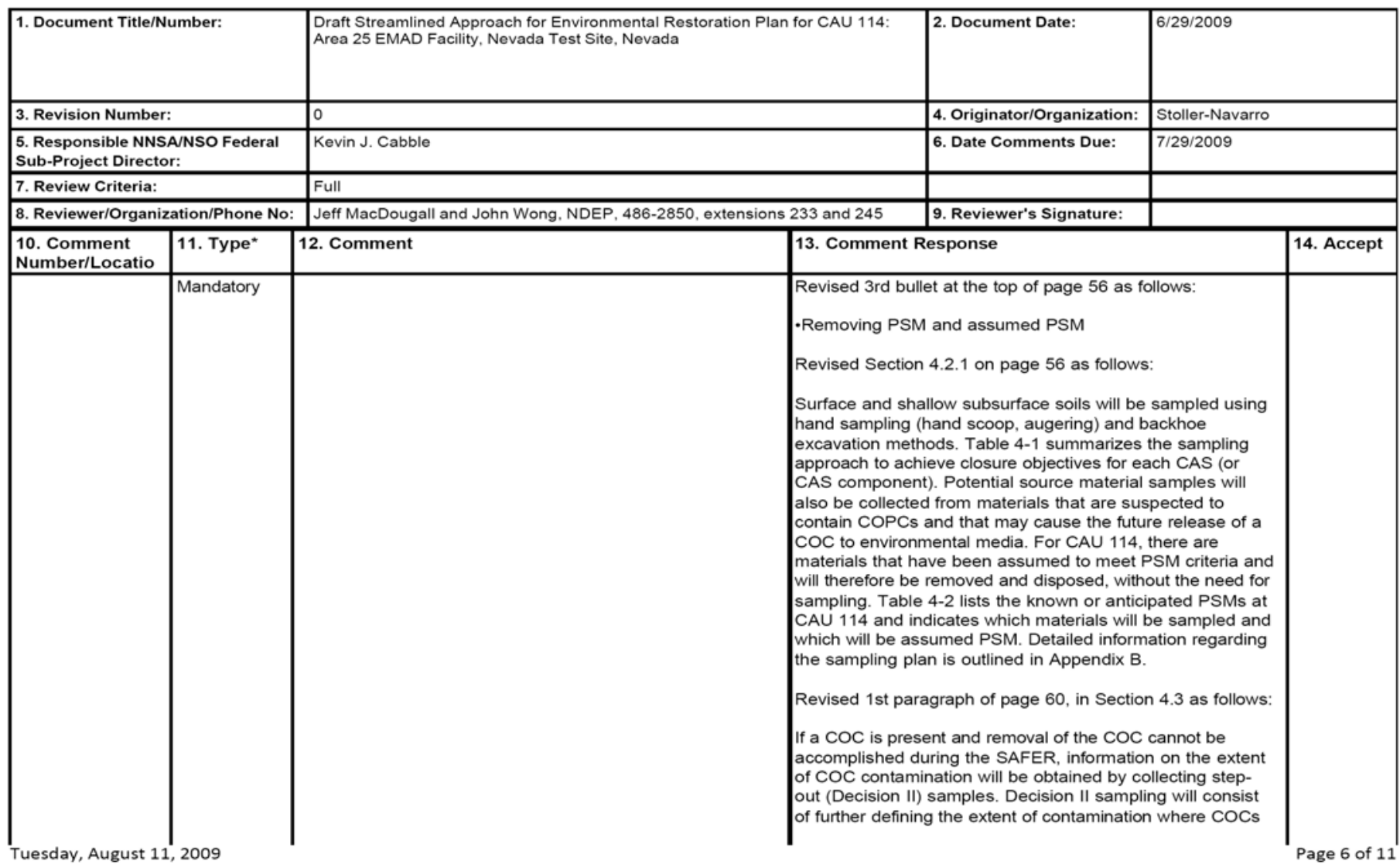




\section{NEVADA ENVIRONMENTAL RESTORATION PROJECT DOCUMENT REVIEW SHEET}

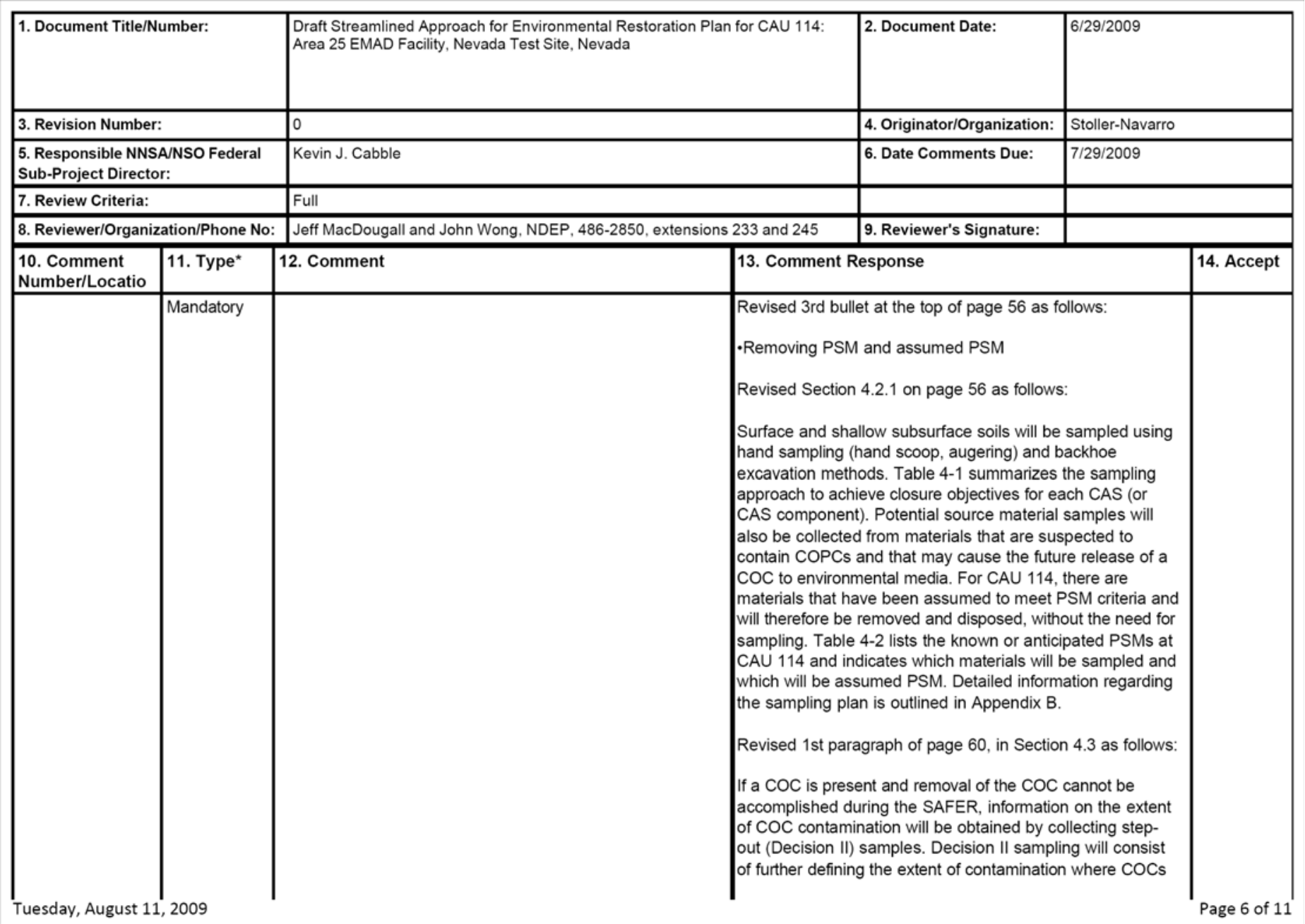




\section{NEVADA ENVIRONMENTAL RESTORATION PROJECT DOCUMENT REVIEW SHEET}

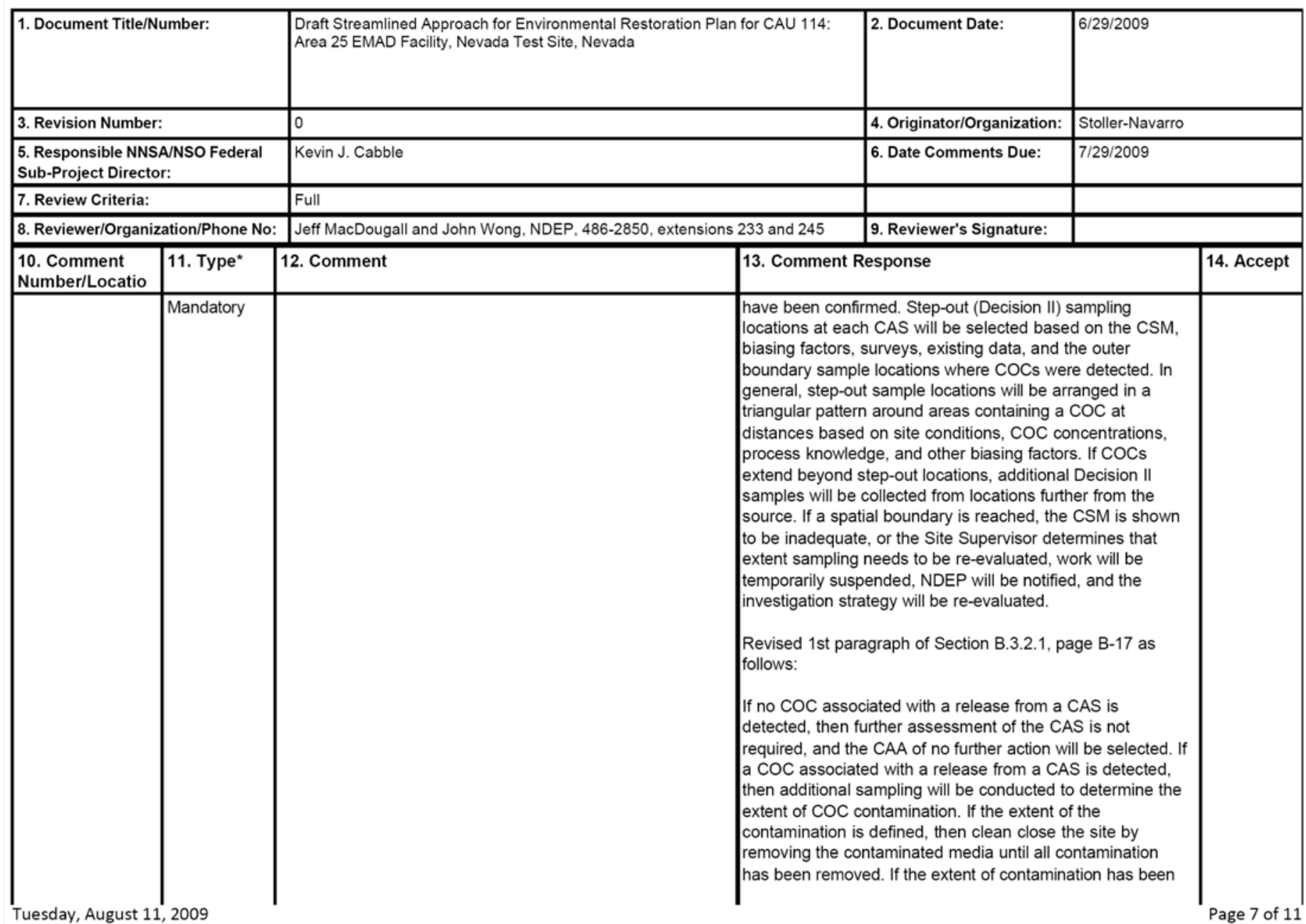




\section{NEVADA ENVIRONMENTAL RESTORATION PROJECT DOCUMENT REVIEW SHEET}

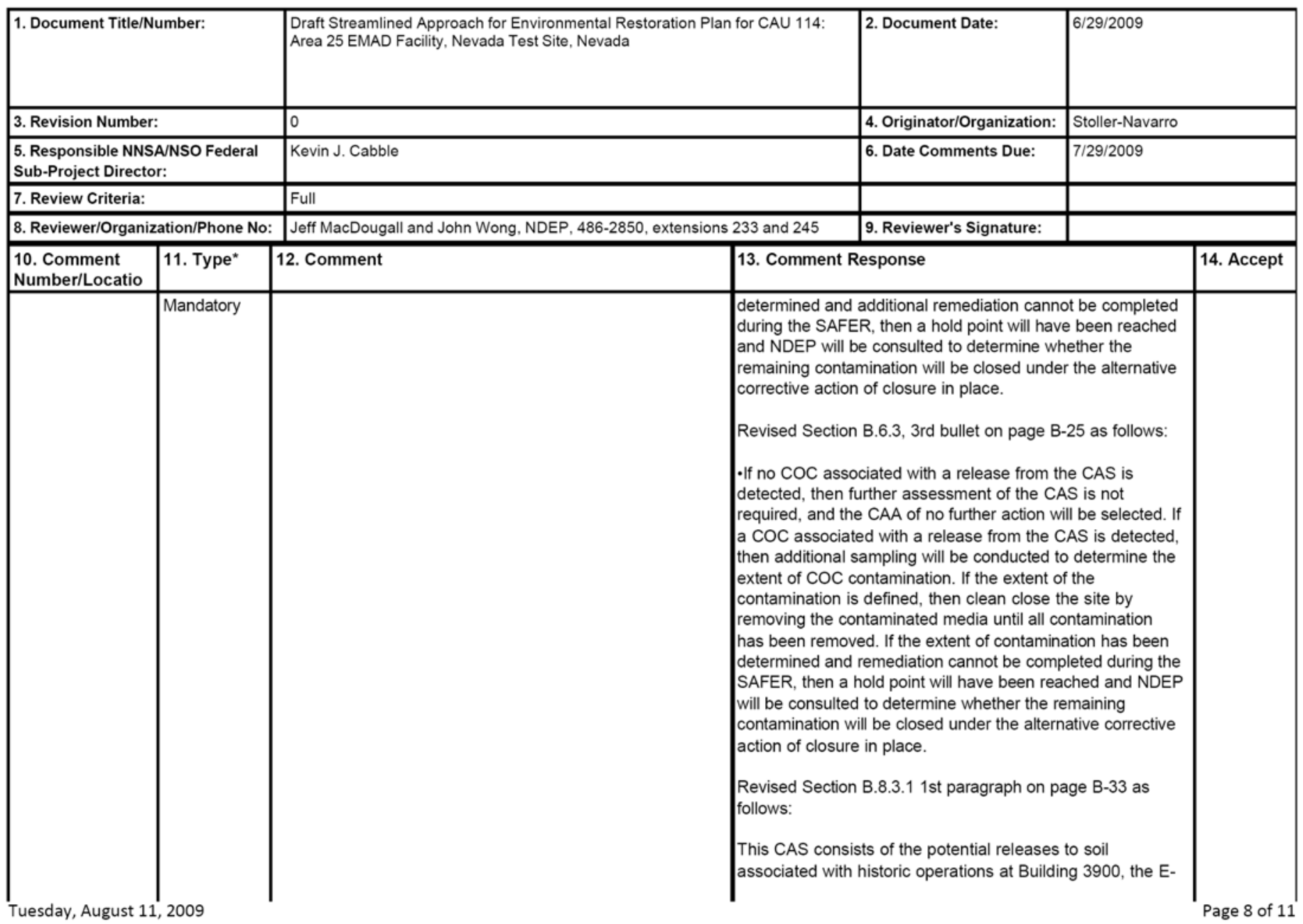

\section{UNCONTROLLED When Printed}




\section{NEVADA ENVIRONMENTAL RESTORATION PROJECT DOCUMENT REVIEW SHEET}

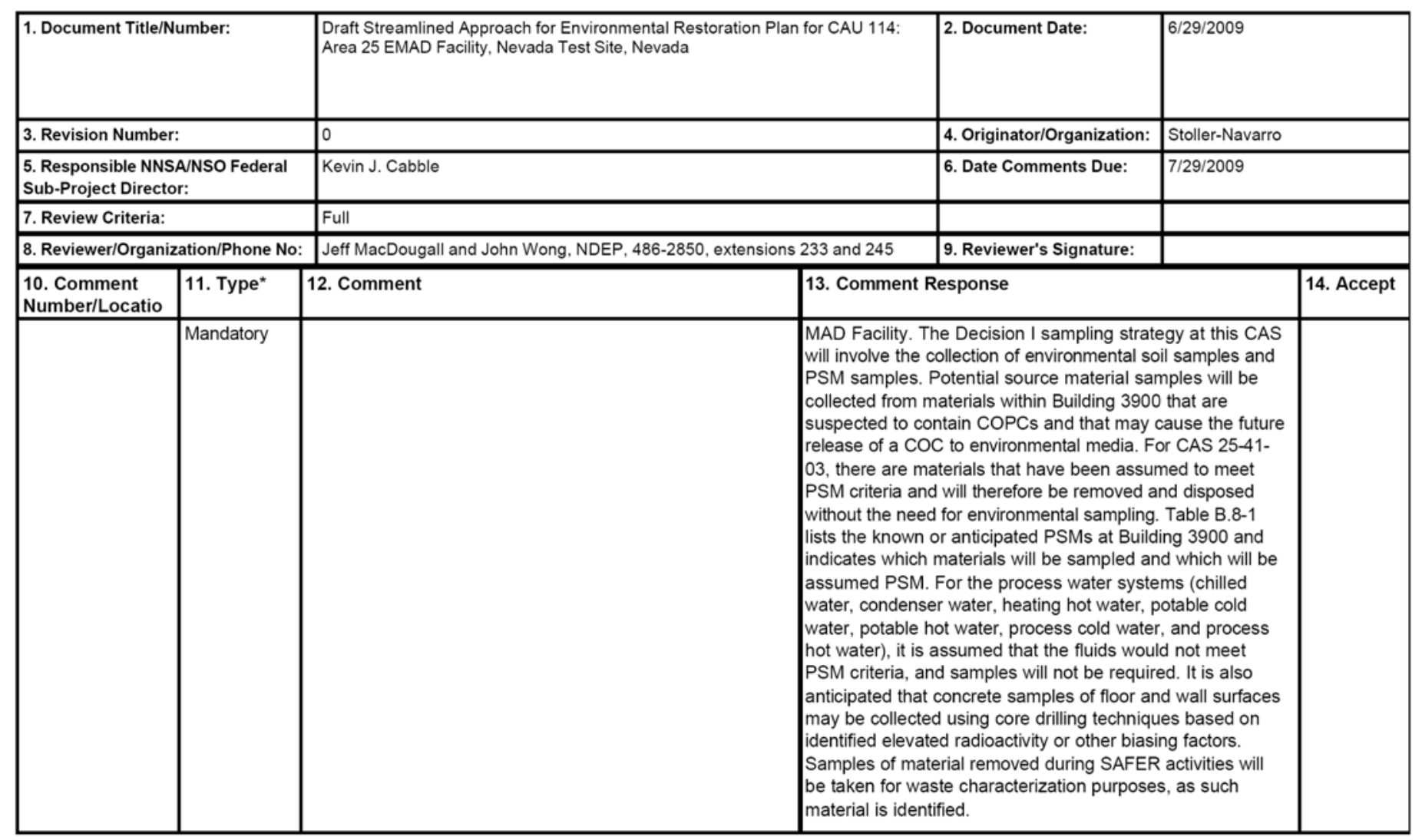




\section{NEVADA ENVIRONMENTAL RESTORATION PROJECT DOCUMENT REVIEW SHEET}

\begin{tabular}{|c|c|c|c|c|c|c|}
\hline \multicolumn{2}{|c|}{ 1. Document Title/Number: } & \multicolumn{2}{|c|}{$\begin{array}{l}\text { Draft Streamlined Approach for Environmental Restoration Plan for CAU 114: } \\
\text { Area } 25 \text { EMAD Facility, Nevada Test Site, Nevada }\end{array}$} & \multirow{2}{*}{\begin{tabular}{|l|} 
2. Document Date: \\
4. Originator/Organization: \\
\end{tabular}} & \multicolumn{2}{|l|}{$6 / 29 / 2009$} \\
\hline \multicolumn{2}{|l|}{ 3. Revision Number: } & \multicolumn{2}{|l|}{0} & & \multicolumn{2}{|l|}{ Stoller-Navarro } \\
\hline \multicolumn{2}{|c|}{\begin{tabular}{|l|} 
5. Responsible NNSA/NSO Federal \\
Sub-Project Director: \\
\end{tabular}} & \multicolumn{2}{|l|}{ Kevin J. Cabble } & 6. Date Comments Due: & \multicolumn{2}{|l|}{$7 / 29 / 2009$} \\
\hline \multicolumn{2}{|l|}{ 7. Review Criteria: } & \multicolumn{2}{|l|}{ Full } & & & \\
\hline \multicolumn{2}{|c|}{ 8. Reviewer/Organization/Phone No: } & : Jeff MacDougall and John Wong, NDEP, 486-2850, extensions & 233 and 245 & 9. Reviewer's Signature: & & \\
\hline $\begin{array}{l}\text { 10. Comment } \\
\text { Number/Locatio } \\
\end{array}$ & 11. Type* & 12. Comment & \multicolumn{3}{|c|}{ 13. Comment Response } & 14. Accept \\
\hline $\begin{array}{l}\text { 4.) Section } 4.3 \text {, } \\
\text { Page } 56\end{array}$ & Mandatory & $\begin{array}{l}\text { It is stated that "...if feasible, removal of COC..."; define } \\
\text { feasible more precisely and also indicate what the course of } \\
\text { action will be in the event that it is determined to be not } \\
\text { feasible to remove COCs. }\end{array}$ & \multicolumn{3}{|c|}{$\begin{array}{l}\text { Based on the response to Comment } 3 \text {, the definition of } \\
\text { "feasible" is no longer needed as the term "feasible" was } \\
\text { deleted from the document. The course of action to be } \\
\text { taken if NNSA cannot complete the planned clean closure } \\
\text { activities was addressed in the response to Comment } 3 \text {. } \\
\text { Revised text in Section 4.3, Page } 56 \text { as follows: } \\
\text { The information necessary to satisfy the closure criteria will } \\
\text { be generated for each CAU } 114 \text { CAS by collecting and } \\
\text { analyzing samples generated during a field investigation. If a } \\
\text { COC is present and removed during the SAFER, verification } \\
\text { sampling of remaining environmental media will be required. } \\
\text { The verification samples will be collected from the } \\
\text { approximate center of the bottom of the excavation below } \\
\text { the stained area and from the lateral boundaries. The final } \\
\text { locations and numbers of verification samples to be } \\
\text { collected will be determined in the field based on the } \\
\text { presence of any biasing factors as listed in Section B.4.2.1, } \\
\text { the size of the excavation, site conditions, and the } \\
\text { professional judgment of the Site Supervisor. All verification } \\
\text { sample locations must meet the DQO decision needs and } \\
\text { criteria stipulated in Appendix B. The number and location } \\
\text { of verification samples will be justified in the CR. }\end{array}$} & \\
\hline
\end{tabular}




\section{NEVADA ENVIRONMENTAL RESTORATION PROJECT DOCUMENT REVIEW SHEET}

\begin{tabular}{|c|c|c|c|c|c|c|}
\hline \multicolumn{2}{|c|}{ 1. Document Title/Number: } & \multicolumn{2}{|c|}{$\begin{array}{l}\text { Draft Streamlined Approach for Environmental Restoration Plan for CAU 114: } \\
\text { Area } 25 \text { EMAD Facility, Nevada Test Site, Nevada }\end{array}$} & \multirow{2}{*}{\begin{tabular}{|l|} 
2. Document Date: \\
4. Originator/Organization: \\
\end{tabular}} & \multicolumn{2}{|l|}{$6 / 29 / 2009$} \\
\hline \multicolumn{2}{|l|}{ 3. Revision Number: } & \multicolumn{2}{|l|}{0} & & \multicolumn{2}{|l|}{ Stoller-Navarro } \\
\hline \multicolumn{2}{|c|}{$\begin{array}{l}\text { 5. Responsible NNSA/NSO Federal } \\
\text { Sub-Project Director: }\end{array}$} & \multicolumn{2}{|l|}{ Kevin J. Cabble } & 6. Date Comments Due: & \multicolumn{2}{|l|}{$7 / 29 / 2009$} \\
\hline \multicolumn{2}{|l|}{ 7. Review Criteria: } & \multicolumn{2}{|l|}{ Full } & & & \\
\hline \multicolumn{2}{|c|}{ 8. Reviewer/Organization/Phone No: } & : Jeff MacDougall and John Wong, NDEP, 486-2850, extensions & 233 and 245 & 9. Reviewer's Signature: & & \\
\hline $\begin{array}{l}\text { 10. Comment } \\
\text { Number/Locatio }\end{array}$ & 11. Type* & 12. Comment & \multicolumn{3}{|c|}{ 13. Comment Response } & 14. Accept \\
\hline $\begin{array}{l}\text { 5.) Section } 4.4, \\
\text { Page } 61\end{array}$ & Mandatory & $\begin{array}{l}\text { Provide a more specific definition of "feasible," by identifying } \\
\text { conditions and criteria which qualify as either "feasible" or } \\
\text { "not feasible" (i.e., what will these decisions be based } \\
\text { on)...in the current context, "feasible" is quite general and } \\
\text { subjective. }\end{array}$ & \multicolumn{3}{|c|}{$\begin{array}{l}\text { Based on the response to Comment } 3 \text {, the definition } \\
\text { "feasible" is no longer needed as the term "feasible" was } \\
\text { deleted from the document. Therefore, this comment was } \\
\text { addressed in the response to Comment } 3 \text {. } \\
\text { Revised text in Section 4.4, Page } 61 \text { as follows: } \\
\text { The following activities, at a minimum, have been identified } \\
\text { for closure of these CASs. The decision logic behind the } \\
\text { activities is provided in Figure 1-4: } \\
\text {-ff no COCs or PSM are identified during SAFER activities, } \\
\text { a CAA of no further action will be selected. } \\
\text {-If COCs or PSM are identified, then a corrective action is } \\
\text { required. } \\
\text {-If COCs or PSM are identified and clean closure cannot be } \\
\text { accomplished during the SAFER, then a hold point will have } \\
\text { been reached and NDEP will be consulted to determine } \\
\text { whether the remaining contamination will be closed under } \\
\text { the alternative corrective action of closure in place. The } \\
\text { appropriate URs will then be implemented and documented } \\
\text { in the CR. } \\
\text {-If COCs or PSM are identified and clean closure can be } \\
\text { accomplished during the SAFER, clean closure will be the } \\
\text { selected corrective action. The material to be remediated } \\
\text { will be removed and disposed as waste, and verification } \\
\text { samples will be collected from remaining soil or debris, as } \\
\text { necessary. Verification analytical results will be } \\
\text { documented in the CR. }\end{array}$} & \\
\hline
\end{tabular}




\title{
Library Distribution List
}

\author{
$\underline{\text { Copies }}$ \\ U.S. Department of Energy \\ 1 (Uncontrolled, electronic copy) \\ National Nuclear Security Administration \\ Nevada Site Office \\ Technical Library \\ P.O. Box 98518, M/S 505 \\ Las Vegas, NV 89193-8518 \\ U.S. Department of Energy \\ Office of Scientific and Technical Information \\ 1 (Uncontrolled, electronic copy) \\ P.O. Box 62 \\ Oak Ridge, TN 37831-0062 \\ Southern Nevada Public Reading Facility \\ 2 (Uncontrolled, electronic copies) \\ c/o Nuclear Testing Archive \\ P.O. Box 98521, M/S 400 \\ Las Vegas, NV 89193-8521 \\ Manager, Northern Nevada FFACO \\ 1 (Uncontrolled, electronic copy) \\ Public Reading Facility \\ c/o Nevada State Library \& Archives \\ 100 N Stewart Street \\ Carson City, NV 89701-4285
}

